\title{
Stirling Engine Alternatives for the Terrestrial Solar Application
}

$\checkmark$ Stearns

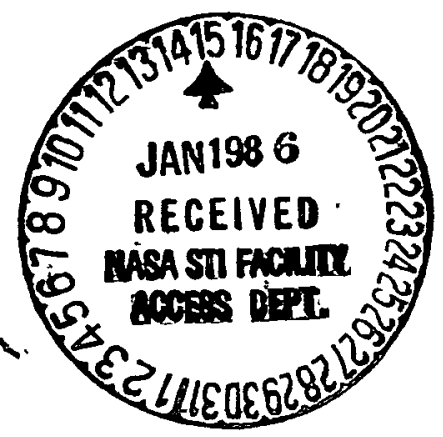

(NASA-CR-176450) STIRIING ENGINE

APPLICATION (Jet PIOPUISIOSTRIAL SOLAB

BC A06/MF AO I.

Prepared for

U S Department of Energy

Through an Agreement with

National Aeronautics and Space Admınıstration

by

Jet Propulsion Laboratory

Calıfornia Institute of Technology

Pasadena, Calıfornı

JPL Publication 85-70 


\title{
Stirling Engine Alternatives for the Terrestrial Solar Application
}

\author{
J. Stearns
}

October 1985

Prepared for

U S Department of Energy

Through an Agreement with

Natıonal Aeronautics and Space Administration

by

Jet Propulsion Laboratory

California Institute of Technology

Pasadena, Calıfornia

JPL Publication 85-70 
Prepared by the Jet Propulsion Laboratory, Calıforma Institute of Technology, for the U S Department of Energy through an agreement with the National Aeronautics and Space Administration (NASA Task RE-152, Amendment 404; DOE/SNLA/NASA Interagency Agreement $P$ O. 25-7651)

The JPL Solar Thermal Power Systems Project is sponsored by the U.S Department of Energy and is part of the Solar Thermal Program to develop low-cost solar thermal and electric power plants

This report was prepared as an account of work sponsored by an agency of the United States Government Neither the United States Government nor any agency thereof, nor any of their employees, makes any warranty, express or implied, or assumes any legal hability or responsibility for the accuracy, completeness, or usefulness of any information, apparatus, product, or process disclosed, or represents that its use would not infringe privately owned rights

Reference hereın to any specific commercial product, process, or service by trade name, trademark, manufacturer, or otherwise, does not necessarily constitute or imply its endorsement, recommendation, or favoring by the United States Government or any agency thereof The views and opınıons of authors expressed herein do not necessanly state or reflect those of the United States Government or any agency thereof 
The first phase of the present study of Stirling engine alternatives for solar thermal-electric generation has been completed. Development risk levels are considered to be high for all engines evaluated. Free-piston type and Ringbom-type Stirling engine-alternators are not yet developed for the 25-to-50-kW electrical power range, although smaller machines have demonstrated the inherent robustness of the machines. Kinematic-type Stirling engines are presently achieving a 3500-hr lifetime or longer on critical components, and lifetime must still be further extended for the solar application. Operational and technical characteristics of all types of Stirling engines have been reviewed with engine developers. Technical work of merit in progress in each engine development organization should be recognized and supported in an appropriate manner. 
CONTENTS

I. INTRODUCTION . . . . . . . . . . . . . . . . 1-1

II. ADVANCED SOLAR TECHNOLOGY REQUIREMENTS . . . . . . . . . . . 2-1

A. PARABOLIC-DISH SOLAR COLLECTORS ............ . 2-1

B. POWER CONVERSION EFFICIENCY . . . . . . . . . . . 2-1

C. OPERATION AND MAINTENANCE . . . . . . . . . . . . . 2-2

III. STIRLING ENGINE DEVELOPMENTS . . . . . . . . . . . . . . 3-1

A. KINEMATIC STIRLING ENGINES . . . . . . . . . . . 3-1

1. Mechanical Technology, Inc./United Stirling AB ... 3-4

2. Societe' ECA, Meudon, France .......... 3-5

3. Stirling Thermal Motors, Inc., Ann Arbor, Michigan . 3-6

B. FREE PISTON STIRLING ENGINES ............. 3-8

1. Mechanical Technology, Inc........... 3-8

2. Sunpower, Inc., Athens, Ohio ........... 3-11

3. Energy Research and Generation, Inc.,

Oakland, California . . . . . . . . . . . 3-13

C. RINGBOM STIRLING ENGINES . . . . . . . . . . . . 3-14

IV. REFERENCES ..................... 4-1

APPENDICES

A. Life AND MAINTENANCE REQUIREMENTS, UNITED STIRLING AB • • A-1

B. LIFE AND MAINTENANCE REQUIREMENTS, STIRLING THERMAL MOTORS, INC. ............ . B-1

C. UTILITY POWER PURCHASE, INCLUDING COMBUSTOR AND THERMAL STORAGE .............. C-1

D. SOUTHERN CALIFORNIA EDISON CO. AVOIDED COST PRICING AND POWER PURCHASE (1984) . . . . . . . . . D-1 
E. MARTINI ENGINEERING, "OVERVIEW OF STIRLING

MACHINE DEVELOPMENT AND APPLICATIONS" . . . . . . . . E-1

\section{Figures}

1-1. 1983 Reference Engine System Design (ASE) . . . . . . 1-2

1-2. In-line Four-Cylinder Stirling Engine (Societe' ECA) . . 1-3

1-3. Variable Swashplate Stirling Engine (Stirling

Thermal Motors, Inc.) . . . . . . . . . . . . 1-4

1-4. Cutaway View of RE 1000 Free-Piston,

Free-Displacer Stirling Engine . . . . . . . . . 1-6

3-1. Ford/Philips Torino Engine ............ . 3-2

3-2. United Stirling $A B$ 4-95 Stirling Engine ....... . 3-3

3-3. Variable Swashplate Stirling Engine Working Diagram . . . 3-7

3-4. Free Piston Stirling Engine Elementary Concept . . . . 3-9

3-5. 25-kWe Free Piston Stirling Engine Space Power

Demonstrator Engine.............. 3-10

3-6. Solarized Space Power Demonstrator Engine Efficiency. . . 3-12

3-7. Detail of 23-kW Free Piston Stirling Engine . . . . . 3-13

3-8. The Elementary Single-Cylinder Ringbom Engine Concept . . 3-15

3-9. Steady-State Operation of a Single-Cylinder Ringbom

with Displacer Stops on the Piston and at the Hot End . . 3-15

3-10. Small Single-Cylinder Ringbom Built at the

University of Wisconsin . . . . . . . . . . 3-16

3-11. Schematic Drawing of a Single-Cylinder Ringbom with

Absolute Displacer Stops at the Hot and the Cold Ends . . 3-16

Tables

1-1. Development Advanced Solar Stirling Engine Estimates . . . 1-7

2-1. Solar Module Efficiency. . . . . . . . . . . . 2-3

3-1. Modeling Assumptions . . . . . . . . . . . 3-17 


\section{SECTION I}

\section{INTRODUCTION}

The dish/Stirling electric power system is a modular solar-thermal-powered electricity generating plant. With each dish/Stirling power subsystem module, the direct insolation irradiating the Earth is focused onto a small prime mover heater surface by pointing a large paraboloidal reflector or Fresnel refractor continually at the sun. On each module, the solar-thermal-powered Stirling engine prime mover then drives an electric generator to produce electricity. The dish/Stirling electric power system is composed of a field array of these distributed dish/Stirling power subsystem modules, in addition to an interconnecting electric power subsystem, a distributed control subsystem, and a centralized information display subsystem.

Stirling engine development over the past 10 yr has been significant. High thermal and mechanical efficiency, recognized as a major potential for Stirling engines for several decades, has been demonstrated. Potential Stirling engine applications in many areas are now being recognized and pursued. Development of practical, long-lifetime machines has been provided by the U.S. Department of Energy in the Automotive Stirling Engine (ASE) Program. Management of the ASE program is by NASA Lewis Research Center.

Stirling engine research and development programs are presently ongoing in Europe, Japan, and the United States. Much of the work is supported by the governments and industrial consortiums; some is by the effort of individual companies. These programs are resulting in the tests of several various Stirling engines. The competition between developments is quite intense at the present, making it possible for the DOE solar program to benefit from the competitive efforts.

Innovative, low-cost solar technology is now moving rapidly toward acceptance in the marketplace. The assurance of higher power, efficiency, and demonstrated low life-cycle cost for advanced solar stirling engines is important to the solar parabolic dish Stirling-engine electrical-generating system's future industry.

A search of the current Stirling engine literature has been completed. Preliminary discussions were held with the engine developers, and preliminary estimates were made of expected operation, performance, lifetime, etc. It was found that there are basically three different segments of the Stirling engine technology development, each having significant merit for the solar application. These are (1) the standard crankshaft engine, (2) the variable swashplate engine, and (3) the free-piston/free-displacer Stirling engine.

The first of these technology developments, the standard crankshaft engine, uses crankshafts with conventional crossheads and connecting rods. One example of a standard crankshaft Stirling engine is a four-cylinder, double-acting piston configuration initially developed by the NV Philips Company, the Netherlands, and subsequently by United Stirling AB, Sweden. Development of this engine for the automotive application is being managed in 
the ASE Program. Contracts to Mechanical Technology, Inc. (MTI) and United Stirling $A B$ have led to the design of a Mod II $V$-drive engine, shown in Figure 1-1, with an engine speed of $1800 \mathrm{rpm}$, producing $35 \mathrm{~kW}$ of shaft power. In addition to this effort, ECA, a submersibles company in France, has designed and built an in-line, four-cylinder Stirling engine shown in Figure 1-2 that, at an engine speed of $1800 \mathrm{rpm}$, will produce $22 \mathrm{~kW}$ of shaft power.

An advanced kinematic Stirling engine shown in Figure 1-3, in which a rotating, variable-angle "swashplate" replaces the crank drive in the engine, is the second technology development. The swashplate Stirling engine, being

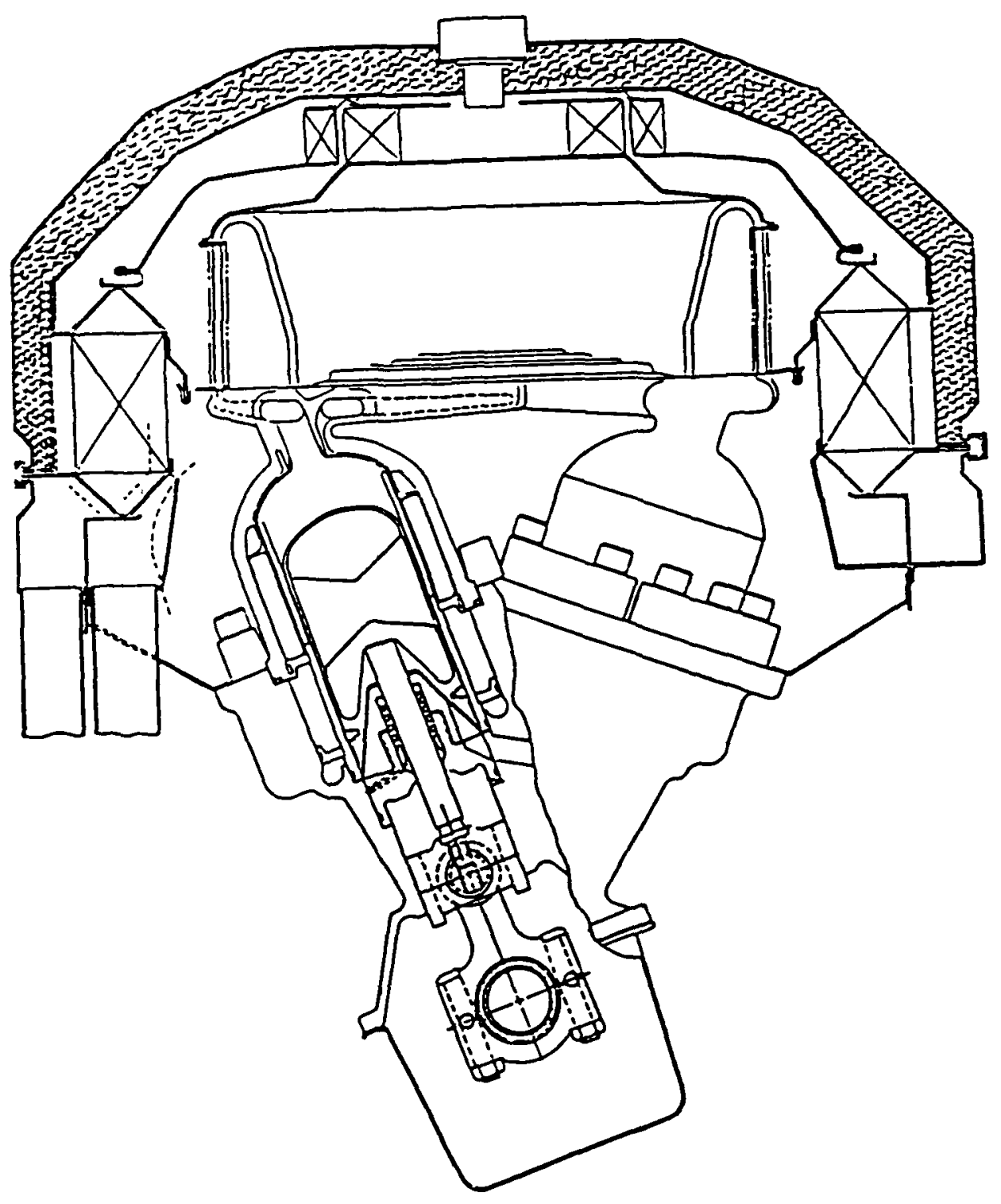

Figure 1-1. 1983 Reference Engine System Design (ASE) 


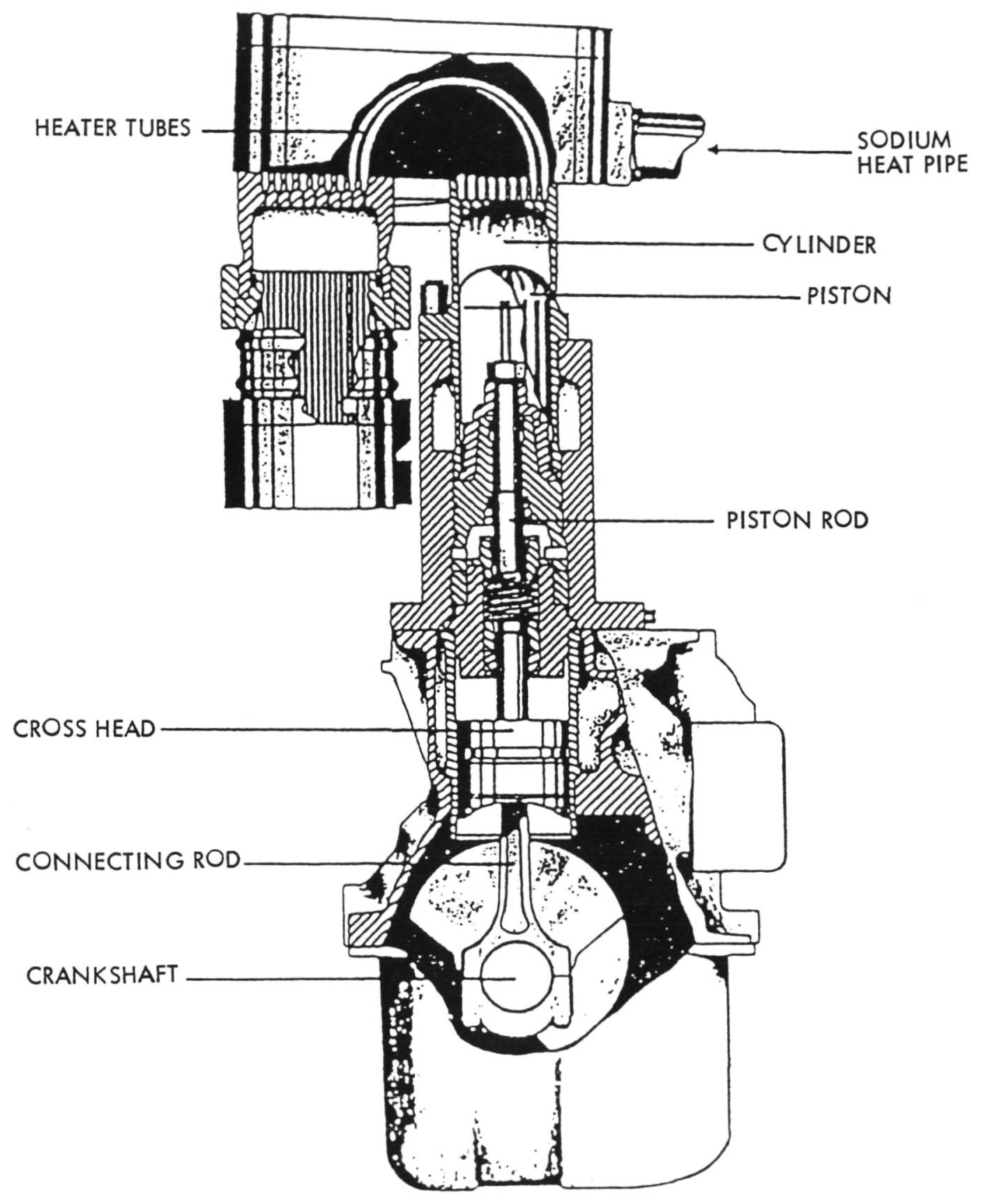

Figure 1-2. In-line Four-Cylinder Stirling Engine (Societe' ECA) 


\section{ORIGINAL PAGE IS}

OF POOR QUALTTY

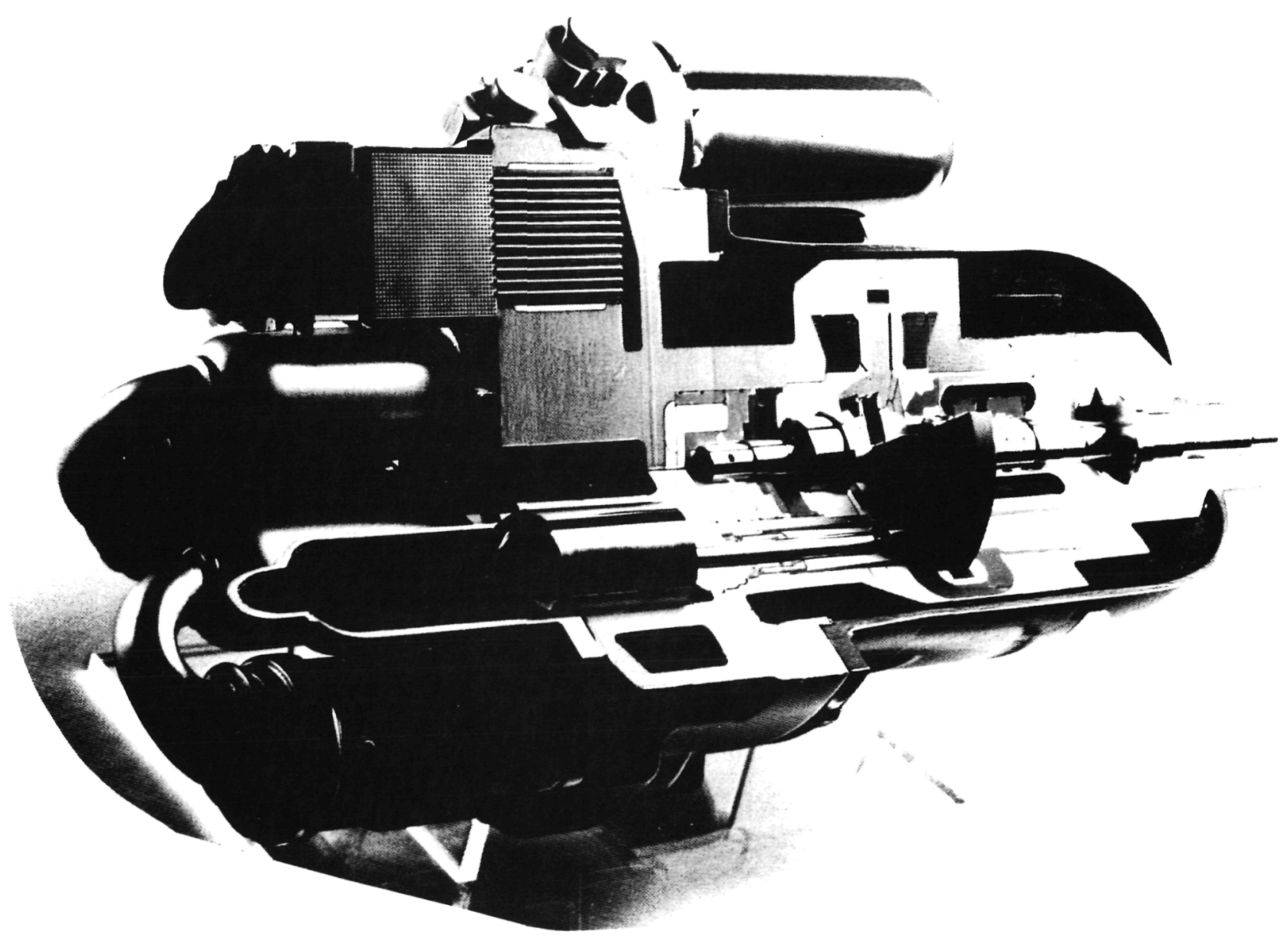

Figure 1-3. Variable Swashplate Stirling Engine (Stirling Thermal Motors, Inc.) 
developed and assembled by Stirling Thermal Motors (STM), Inc., of Ann Arbor, Michigan, was also initially developed by NV Philips Company in the Netherlands. The drive for the swashplate Stirling engine is a sealed, pressurized hydraulic unit. The oil pressure in the hydraulic drive is set at the mean pressure of the helium working gas in the stirling cycle. This oil and working gas pressure is maintained constant in the swashplate engine, eliminating the pressure control complexity of previous Stirling engines. A simple, ingeniously geared control of the swashplate angle provides for variable power output, thus keeping a nearly constant engine efficiency at partial power, especially important to the solar dish/Stirling system application because of varying direct insolation. A pressure drop is no longer required across the primary seal between the engine drive and the working gas of the Stirling cycle, thus eliminating another major failure mechanism.

The third distinct Stirling engine technology development is the oscillating, free-piston/free-displacer Stirling engine, seen in Figure 1-4. Included is the so-called "Ringbom" Stirling engine, in which a control drive is provided for either the working piston (the original Ringbom patent) or the displacer. The piston and displacer are the primary components of two, inter-acting spring-mass systems. A permanent magnet-1inear alternator is usually attached to the working piston for generating an ac output. Hermetically sealed with gas-bearing suspension, the operation of the engine is nearly wear-free. Inherent robustness of the free-piston technology has been demonstrated in engine-generators with up to $3 \mathrm{~kW}$ of electrical power. Test times now exceed $1000 \mathrm{hr}$. By insertion of the additional control drive for either the piston or displacer, Energy Research and Generation (ERG), Inc., has shown that performance of the engine may be improved, particularly for constant-frequency operation (Reference 1). Development of a 25-kWe-power engine for space electrical power is now in progress at MTI (Reference 2). Ringbom-type engine development is being done by the Joint Center for Graduate Studies (JCGS), University of Washington.

In addition to the development of the fundamentally different Stirling engine drives, considerable technology advance is being made in the Stirling cycle components and materials. Advanced, low-cost metal alloys and ceramics are being introduced into the engine hot parts to further improve 1 ife and performance. Heat pipe heater heads are being developed to improve heat transfer characteristics for better performance. Isothermalization concepts are being added to the Stirling cycle to more closely approach the Carnot cycle efficiency. There is, perhaps, careful evaluation being done for every critical component of these several different Stirling engines to reduce life-cycle cost, consistent with improved performance, reliability, life, producibility, etc. Significant improvement and growth across the entire technical spectrum in Stirling engines are now being demonstrated.

A tentative overall comparison of the various Stirling engine developments is shown in Table 1-1. A detailed discussion of the engine developments is provided in the following sections of this report, together with an estimate of their potential for meeting the requirements of the solar dish/Stirling system application. 


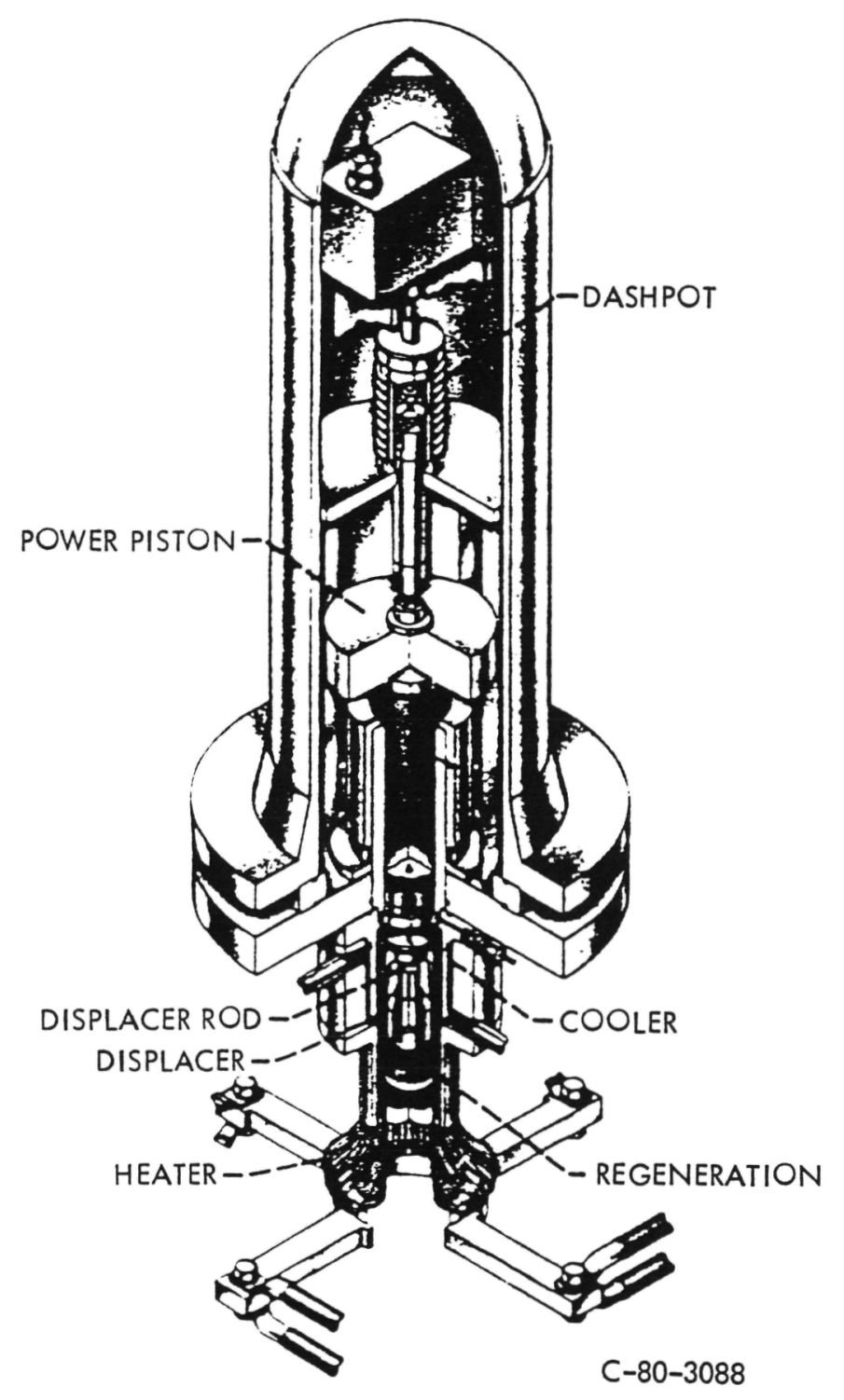

Figure 1-4. Cutaway View of RE-1000 Free-Piston, Free-Displacer Stirling Engine 
Table 1-1. Developmental Advanced Solar Stirling Engine Estimates

\begin{tabular}{|c|c|c|c|c|c|c|c|}
\hline \multirow{2}{*}{$\begin{array}{l}\text { Basic Engine Drive } \\
\text { Engine/Developer } \\
\text { (Information Source) }\end{array}$} & \multicolumn{2}{|c|}{ Crankcase } & \multicolumn{2}{|c|}{$\begin{array}{l}\text { Hydraulic } \\
\text { Swashplate }\end{array}$} & \multicolumn{3}{|c|}{ Free Piston/Displacer } \\
\hline & $\begin{array}{l}\operatorname{ASE}^{\mathrm{a}} \\
\text { Mod I I } \\
\text { MT I }\end{array}$ & $\begin{array}{c}\text { In-1 ine } \\
4-113 \\
\text { ECA }\end{array}$ & $\begin{array}{c}4-120 \\
\text { STM }\end{array}$ & $\begin{array}{c}\text { FPSE } \\
\text { Sunpower }\end{array}$ & $\begin{array}{l}\text { FPSE } \\
\text { MTI }\end{array}$ & $\begin{array}{l}\text { FPSE } \\
\text { ERG }\end{array}$ & $\begin{array}{l}\text { Ringboin } \\
\text { JCGS }\end{array}$ \\
\hline \multicolumn{8}{|l|}{$\begin{array}{l}\text { Estimated } \\
\text { Performance }\end{array}$} \\
\hline $\begin{array}{ll}\text { Ful1 } & \text { power } \\
0.25 & \text { power }\end{array}$ & $\begin{array}{l}0.45 \\
0.35\end{array}$ & $\begin{array}{l}0.45 \\
0.35\end{array}$ & $\begin{array}{l}0.48 \\
0.45\end{array}$ & $\begin{array}{l}0.40 \\
0.35\end{array}$ & $\begin{array}{l}0.40 \\
0.35\end{array}$ & $\begin{array}{l}0.50 \\
0.45\end{array}$ & $\begin{array}{l}0.50 \\
0.40\end{array}$ \\
\hline $\begin{array}{l}\text { Overhaul Life } \\
\left(\mathrm{h} \times 10^{3}\right)\end{array}$ & 10 & $30(?)$ & $20-60$ & 60 & 60 & 60 & $60(?)$ \\
\hline Scaleability (kW) & 150 & 250 & 500 & 25 & 25 & 60 & $100(?)$ \\
\hline $\begin{array}{l}\text { Heat Pipe Receiver } \\
\text { Potential }\end{array}$ & no & yes & yes & yes & yes & yes & yes \\
\hline Hybrid Potential & no & yes & yes & yes & yes & yes & yes \\
\hline Rotary Output & yes & yes & yes & no & no & no & yes \\
\hline Working Gas & $\mathrm{H}_{2}$ & $\mathrm{He}$ & $\mathrm{He}$ & $\mathrm{He}$ & $\mathrm{He}$ & $\mathrm{He}$ & $\mathrm{He}$ \\
\hline $\begin{array}{c}\text { Design Complete } \\
\text { (if funded) }\end{array}$ & 1985 & 1985 & $1984^{b}$ & $1986-7$ & $1986-7$ & 1987 & 1987 \\
\hline $\begin{array}{l}\text { Test Complete } \\
\text { (if funded) }\end{array}$ & 1986 & 1986 & 1985 & $1987-8$ & $1987-8$ & 1988 & 1988 \\
\hline Production Plan & -- & -- & $1987-8$ & $?$ & $?$ & $?$ & $?$ \\
\hline $\begin{array}{l}\text { Prototype Cost, } \$ M \\
\text { (engine on } 1 y \text { ) }\end{array}$ & $0.5-1$ & 1.5 & $0.5-1$ & $2-4$ & $2-4$ & $4-8$ & $4-6(?)$ \\
\hline
\end{tabular}

a Availability for the solar application is presently limited by an exclusive license with McDonnell Douglas Corporation.

${ }^{\mathrm{b}}$ Design completed. 


\section{ADVANCED SOLAR TECHNOLOGY REQUIREMENTS}

The functional requirements of Stirling engine size, perfornance, and reliability are imposed by the dish/Stirling system. The comparatively high life cycle cost of the parabolic dish solar collector is recognized as a primary system constraint imposing high demands of the power conversion unit (PCU). The operating features that make the dish/Stirling system more acceptable as an electrical generating plant are also considered. Thus, to meet power demand, buffer thermal energy storage and auxiliary fuel-fired heating may be needed. Overall efficiency and reliability should be increased, consistent with low life-cycle cost components.

\section{A. PARABOLIC-DISH SOLAR COLLECTORS}

Size optimization for the parabolic-dish solar concentrators, now being defined by the "innovative concentrator" development, is expected to be in the 15-m-diameter size. Module power output by the Stirling engine-generator may thus be increased to approximately 50 to $60 \mathrm{kWe}$. The geometric solar concentration ratio (GCR) is upwardly approaching 3000. The Vanguard dish by Advanco Corporation has a GCR of 2800 with a $20-\mathrm{cm}$ receiver aperture and a parabolic dish aperture of $10.6 \mathrm{~m}$. The LaJet dish has an approximately 2500 GCR, while solar collector (concentrator plus receiver) installed cost is estimated at high quantity to be from $\$ 150$ to $\$ 300 / \mathrm{kWt}$. In practice, therefore, there appears to be little, if any, collector cost advantage for a concentration ratio below 2500 to 3000. Selection of the GCR will be dependent on other system-specific criteria.

The PCU mass at the parabolic-dish focal point may be quite high. Studies as in Appendix $C$ continue to show the value of adding a hybrid fuelfired combustor and thermal energy storage to the PCU. Thermal energy storage mass is approximately $17 \mathrm{~kg} / \mathrm{kWhe}$, while combustor mass may be 3 to $5 \mathrm{~kg} / \mathrm{kWe}$. By use of a heat pipe solar receiver, the addition of thermal energy storage and a fuel-fired combustor is simplified. If needed, the ratio of focal length to diameter of the dish may be reduced, with the resulting increased rim angle tending to reduce the structural weight. Added revenue value of $2 \mathrm{hr}$ of thermal energy storage (TES) and a fuel-fired combustor is approximately $27 \%$ above that of the solar-only system. The incremental increase of system initial cost by adding $2 \mathrm{hr}$ of TES and a combustor to the dish-Stirling module has been estimated at approximately $\$ 100$ to $\$ 150 / \mathrm{kWe}$ in production quantities. (The TES salts cost approximately $\$ 0.40 / \mathrm{kg}$, or under $\$ 14 / \mathrm{kWe}$ peak.) Fuel for the combustor operation has been subtracted from system revenue value in Appendix C. Thus, based on the solar-only energy output of $61582 \mathrm{kWhe}$, the net revenue value increase is $\$ 0.019 / \mathrm{kWhe}$, or $\$ 46.69 / \mathrm{kWe} / \mathrm{yr}$.

\section{B. POWER CONVERSION EFFICIENCY}

The large solar energy collectors represent a relatively high installed cost to the dish/Stirling system. Thus, high efficiency of power conversion has a very strong payoff. The Stirling engine, at over $40 \%$ efficiency, will 
produce a system solar-to-electric net peak efficiency of $30 \%$ or more. In the more distant future, the Stirling engine brake or shaft efficiency may increase to $60 \%$ or more, as discussed in Section III.B.3, and solar-to-electric net efficiency would then be expected to be approximately $40 \%$. At an engine brake efficiency of $40 \%$, an installed collector cost of $\$ 150$ to $\$ 200 / \mathrm{kWt}$ corresponds to $\$ 400$ to $\$ 600 / \mathrm{kWe}$ (peak). Solar-only PCU production cost is currently estimated at approximately $\$ 150 / \mathrm{kWe}$ (peak), including conditioning and controls, in quantities of 25,000 units/yr. The balance of plant may be as high as $\$ 200 / \mathrm{kWe}$. Thus, the turnkey cost to the utility of a complete plant will be under $\$ 1000 / \mathrm{kWe}$. This appears to be consistent with a solar-only revenue value of $\$ 0.066 / \mathrm{kWhe}$, shown in Appendix $\mathrm{C}$, including an annual return on investment in excess of $20 \%$.

At startup of production, an initial production rate is thought to be approximately 1000 units/yr. Production cost for, say, 50-kWe engine-generators is estimated at approximately $\$ 20,000$ to $\$ 25,000$ or $\$ 400-\$ 500 / \mathrm{kWe}$. If the collector cost is approximately $\$ 200-\$ 300 / \mathrm{kWt}$, total module cost is highly dependent on power conversion efficiency. At a net engine-generator efficiency of 0.45 , collector cost will be approximately $\$ 600 / \mathrm{kWe}$ peak and equivalent module cost may be $\$ 52,000$, or $\$ 1050 / \mathrm{kWe}$ (peak), in quantities of $1000 / y r$. The balance of the plant cost of $\$ 200 / \mathrm{kWe}$, with over $2 \%$ O\&M costs, will put considerable pressure on the energy sales price of $\$ 0.066 / \mathrm{kWhe}$. If PCU efficiency drops below $45 \%$, the value of early, small production quantities may not cover the installed system cost unless 5-yr or longer energy contracts can be negotiated. Such an approach puts a risk on future earnings. Thus, prior to full-scale production, there must be real emphasis on the increased power conversion efficiency available from the Stirling engines.

A consideration of system and component efficiencies for the dish/Stirling module is seen in Table 2-1 taken from Reference 3. Two sets of Stirling engine efficiencies are shown: with and without significant

technology improvement. Increased efficiency for each set is accomplished by increasing solar receiver temperature (Reference 4). This can be done by converting to ceramic materials (such as silicon carbide, silicon nitride, or zirconia) for the hot parts. Ceramic technology is available at this time to proceed with engine designs.

\section{OPERATION AND MAINTENANCE}

Because O\&M costs in an electric generation facility will reduce profit, they should be minimized as much as possible. Presently, operation of equipment is being automated. Remote supervisory and switching functions may, however, be added at a future date. It is also essential to maximize intervals between servicing periods, to develop maximum module reliability, and to extend lifetime between overhauls. By use of a large number of small modules, reliability design also takes advantage of cost-effective modular redundancy.

Several Stirling engine equipment developers have indicated that the latest design criteria have potential for significant improvements. Specific targets are suggested as: 
Table 2-1. Solar Module Efficiency

Receiver Temperature

$\begin{array}{rrrrrr}{ }^{\circ} \mathrm{C} & 720 & 820 & 920 & 1011 & 1149 \\ \mathrm{O}_{\mathrm{F}} & 1328 & 1508 & 1688 & 1850 & 2100 \\ \mathrm{O}_{\mathrm{K}} & 993 & 1093 & 1193 & 1284 & 1422\end{array}$

$\begin{array}{lccccc}\text { Receiver efficiency } & 0.905 & 0.895 & 0.885 & 0.87 & 0.835 \\ \text { Collector efficiency } & 0.81 & 0.795 & 0.78 & 0.765 & 0.735\end{array}$

Engine efficiency

Present Stirling technology

$0.40^{\mathrm{a}} \quad 0.46^{\mathrm{b}}$

0.49

0.51

0.53

\% Carnot

$(0.6) \quad(0.65)$

$(0.67)$

$(0.68)$

$(0.69)$

Advanced Stirling technology
0.58
0.605
0.625
0.65

\% Carnot

$(0.82) \quad(0.83)$

$(0.835)$

$(0.84)$

Solar-electric efficiency

$\begin{array}{lccccc}\text { Stirling } & 0.30 & 0.34 & 0.36 & 0.37 & 0.37 \\ \text { Stirling, advanced } & & 0.43 & 0.44 & 0.45 & 0.45\end{array}$

anited Stirling $A B$ 4-95 Stirling engine.

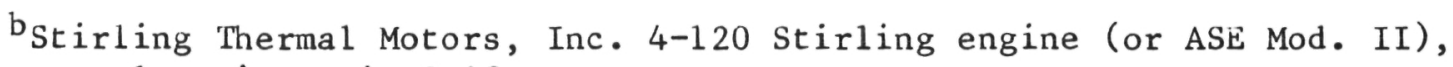
actual estimate is 0.48 .

NOTES 1. Engine working gas temperature $30-50^{\circ} \mathrm{C}$ lower than receiver's temperature.

2. Stirling cycle efficiency curves may have steeper slopes than do the Carnot curves (Reference 3 ). 
(1) Preventive maintenance of engine-related operating equipment is not expected between overhaul periods, except as in Items 2 and 3 below.

(2) Servicing of expendables and changeout of random failure items occur at annual intervals.

(3) Recovery from faults induced by lightning and vandalism (gunfire) must be a design objective.

Utilizing a $10 \%$ parts changeout criterion and $37 \mathrm{hr}$ of 1 abor investment, early Stirling PCU overhaul cost will be approximately $\$ 3300$ for each overhaul. The Stirling engine-alternator is capable of 25 to $50 \mathrm{kWe}$ peak output at 1800 to $3600 \mathrm{rpm}$ and reasonable efficiency (40 to $45 \%$ ). Thus, overhaul/replacement cost is roughly $\$ 100 / \mathrm{kWe}$.

If we also assume MTBO parametrically at $3 \times 10^{3}, 10^{4}$, and $3 \times 10^{4} \mathrm{hr}$, over a 20 -yr system 1 ifetime, this represents 20,6 , and 2 overhaul/replacement periods, at an average cost of $\$ 100, \$ 33$, and $\$ 10$ per $\mathrm{kWe} / \mathrm{yr}$, respectively. The "present value" of such maintenance cost is roughly $\$ 1000, \$ 330$, and $\$ 100 / \mathrm{kWe}$. If a $20-\mathrm{yr}$ capital recovery factor is also applied $(\mathrm{CRF} \sim 0.15)$, the annualized cost is $\$ 150, \$ 50$, and $\$ 15$ per $\mathrm{kWe} / \mathrm{yr}$. The levelized energy cost (LEC) for maintenance ( $2400 \mathrm{kWhe} / \mathrm{yr}$ per $\mathrm{kWe}$ for solar-only) is then of the order of $\$ 0.06$, $\$ 0.02$, and $\$ 0.006 / \mathrm{kWhe}$, respective1y. Compared to a maximum energy payment expectation of $\$ 0.07$ to $\$ 0.10 / \mathrm{kWhe}$, maintenance cost must be kept well below $\$ 0.02 / \mathrm{kWhe}$. Thus, we can then estimate that it will be necessary for MTBO to be $10^{4} \mathrm{hr}$ or greater.

The independent governing component failure modes contributing to MTBF are on those components that must be changed during PCU overhaul. Such items may include receiver insulation and aperture, heater heads, regenerators, piston rings, piston rod seals, bearings, filters, auxiliary motors, shock mounts, and control valves. A maximum of 30 such items appears at present to be a reasonable estimate. Thus, an engine MTBO of $10^{4}$ to $3 \times 10^{4} \mathrm{hr}$ requires MTBF of critical components of $3 \times 10^{4}$ to $10^{5} \mathrm{hr}$. Such design specifications have been suggested for the advanced Stirling engine developments now in progress.

Early solarized engines are of the automotive design, where maintainability is considered essential. However, next-generation equipment is being developed emphasizing the elimination of preventive maintenance. Engines are sealed, with design life goals of at least $3 \times 10^{4} \mathrm{hr}$. Other elements of the systems will have overhaul/replacement intervals of at least $10 \mathrm{yr}$ (in excess of $30,000 \mathrm{hr}$ ). Today, in 1985, test times have successfully exceeded $4000 \mathrm{hr}$ and are approaching $10,000 \mathrm{hr}$ in solarized engines at United Stirling $A B$, Malmo, Sweden.

A preliminary estimate of engine 1 ife has been shown in Table 1-1. Piston rings, piston rod seals, and heater heads are limiting in the crankcase engines. Main shaft bearings temporarily limit the swashplate engine. Heater heads are potentially limiting in the free-piston/free-displacer engines. Details of reliability and performance are provided in the following section. 
As noted in the previous sections of this report, Stirling engine technology development is in progress for several types of engines. It should also be stated that this report, rather than being just another survey and listing of future Stirling engines, is meant to be a critical assessment of their potential for application to solar thermal-electric generation. Previous, more general surveys by Stine (Reference 5) and Martini (Appendix E) have been of considerable value in the early preparations of this current study.

A fairly careful review has been made of seven specific Stirling engines for this report. These engines are in development, with considerable extrapolation from earlier Stirling engines and component tests. Because of this, the engines evaluated all involve considerable risk in development. However, there are also potentially large payoffs associated with the risk. High efficiency, long life, low cost and early availability at usable power levels are specific criteria that are important to payoff. The assessment of these payoff criteria is the subject of this report. A follow-on benefit/ cost/risk assessment will be made in the future for those candidate Stirling engines where payoff is considered to be highest.

In addition to the engine development reported here, several Stirling engine developments are under way in Japan. The work there is aimed specifically at non-solar applications within that country. There is apparently very little interest by Japan in including the solar application or working with other nations in the development of Stirling engines at this time. Thus, the discussions of these engines in the 1984 IECEC Proceedings (Reference 6) and by Martini (Appendix E) are considered adequate for the present.

\section{A. KINEMATIC STIRLING ENGINES}

Invented by the Rev. Robert Stirling in 1816, the Stirling engine was a 19 th Century phenomenon. But in the 20th Century, after nearly a half-century eclipse by the internal combustion engine, modern kinematic Stirling engine work was only initiated by the Philips Company of Eindhoven, The Netherlands, during World War II. The early "hot air" engine development was aimed at auxiliary power to replace the chemical storage battery for remote sites. It was not until after 1948 that helium and hydrogen were introduced as the working gas at much higher pressure than previously used, and efficiencies above $35 \%$ were obtained. Also in 1948, Dr. Roelf Meijer introduced the rhombic drive engine (Reference 7 ). Although the double acting engine was also invented at Philips in 1947 (Reference 8), the development of the rhombic drive engines continued until 1965. Thereafter, the double acting Stirling engine was developed with a swashplate drive, with Ford Motor Company as a licensee from 1972 until 1978 (Figure 3-1).

In 1968 United Stirling (Sweden) became a licensee of Philips. The fourcylinder, double-acting engine was developed at United Stirling, first with a V-drive crank system and, later, with a U-drive crankcase (Figure 3-2). By 1979, development had proceeded far enough to consider its selection for test with a solar parabolic dish (Reference 9). 


\section{ORIGINAL PAGE IS \\ OF. POOR QUALTY}

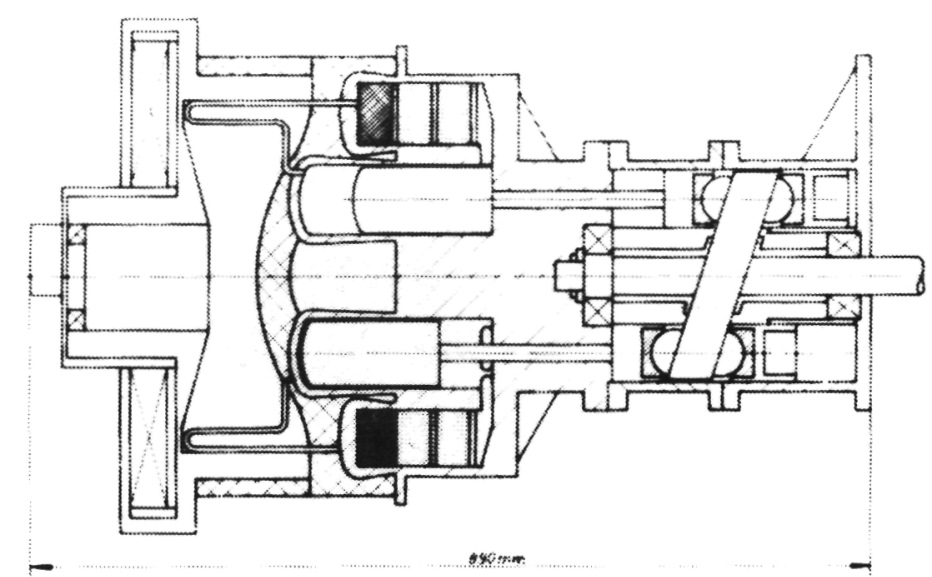

(a) Schematic of Ford/Philips Torino Engine

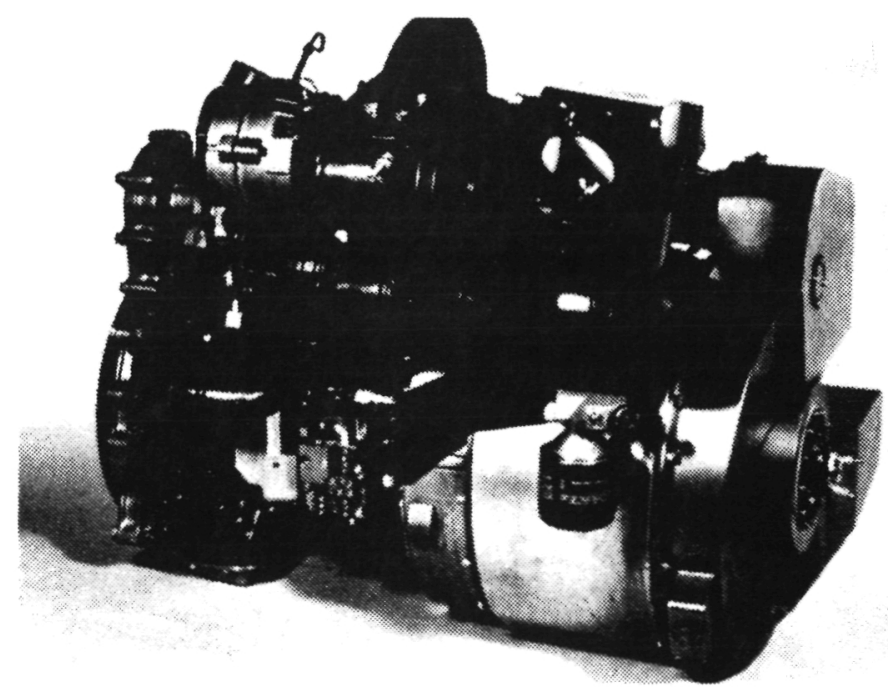

(b) 175-HP Four Cylinder Double-Acting Type Stirling Engine with Swashplate Drive to be Mounted into a Ford Torino Automobile

Figure 3-1. Ford/Philips Torino Engine 


\section{ORIGINAL PAGE IS
OF POOR QUALITY}

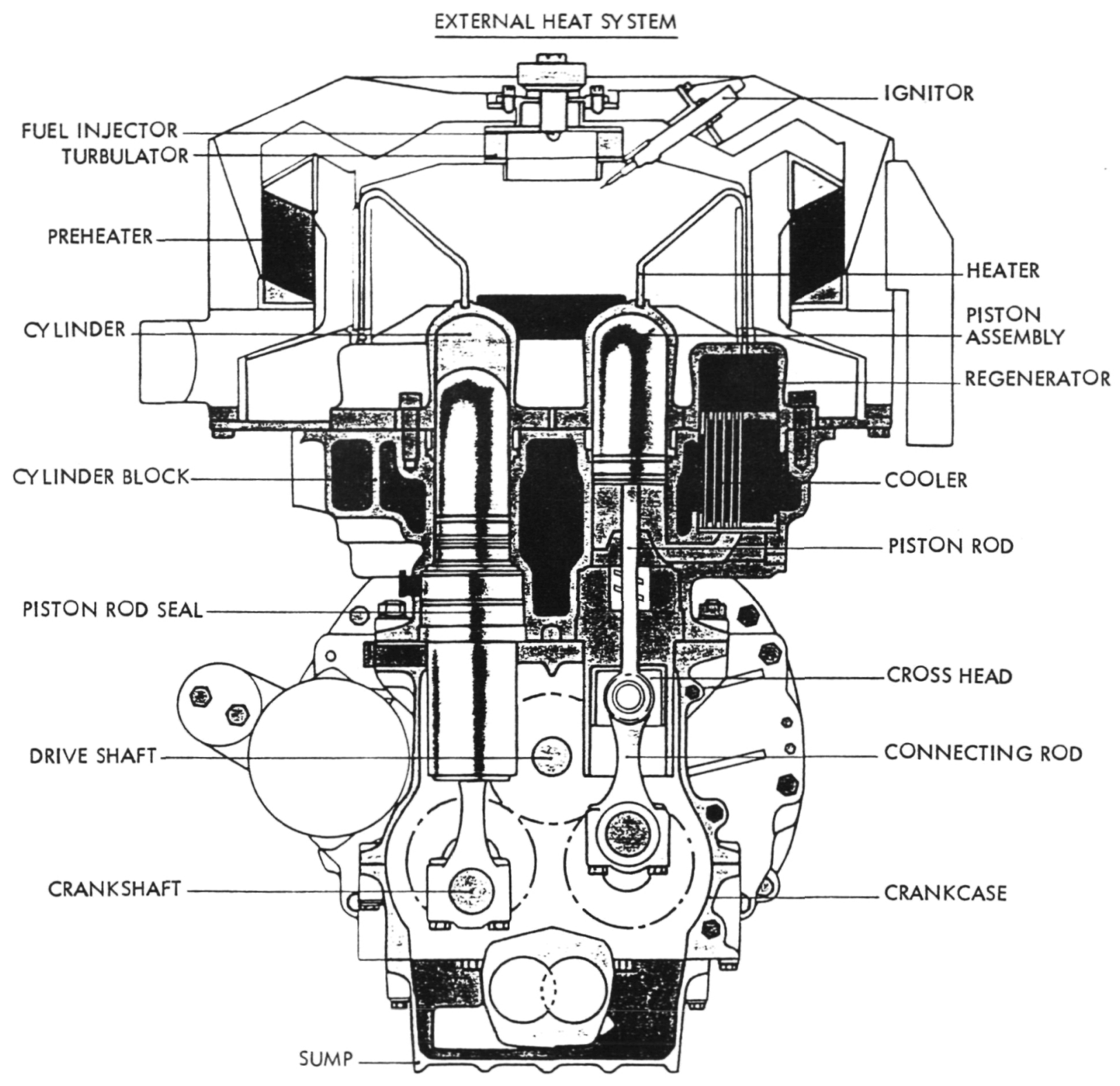

Figure 3-2. United Stirling AB, 4-95 Stirling Engine 
1. Mechanical Technology, Inc./United Stirling $A B$

The original 4-95 Stirling engine baseline has evolved, through the Automotive Stirling Engine (ASE) program, to the existing Mod I and advanced Mod II engines. The Mod II design, shown in Figure 1-1, is a single-crankshaft, $\mathrm{V}$-block, four-cyclinder Stirling engine. A single regenerator and cooler are now annular to each double-acting piston. A cast iron block, integral with the crankcase, includes gas ducts, control lines, crosshead guides and a water jacket. An auxiliary drive provides nearly perfect balancing. This approach will produce a higher-efficiency engine than the existing Mod $I$, and will be lightweight and exceptionally low in cost. New digital controls and a crankcase starter have been introduced. The $60-\mathrm{kW}(35 \mathrm{~kW}$ at $1800 \mathrm{rpm}$ ) system mass is $173 \mathrm{~kg}$. Rolling element bearings will significantly reduce friction. Elimination of an extra crankshaft, driveshaft and gears will also improve efficiency. The heater head temperature has been increased to $820^{\circ} \mathrm{C}$ with low-cost materials, but at this temperature, creep life is roughly $8000 \mathrm{hr}$. Peak shaft efficiency is over $40 \%$, and is ultimately expected to be $45 \%$. Stirling system cost is $\$ 1314$ for production volume of $300,000 / y r$. The capitalization and tooling cost is approximately $\$ 43 \mathrm{million}$ (Reference 10).

Seal reliability in the ASE program is being improved constantly. Piston rod main seals are now being shown to have long 1 ife, provided that tight tolerances are maintained on the crosshead guides (References. 11,12). Leak-free operation eliminates contamination of piston rings and thus assures piston-ring life. Because of start-up pressure requirements, preload on the double piston rings is relatively high, and life is expected to be 3000 to 4000 hr (Appendix A).

Engine wear-out for the Stirling engine is not yet well defined. Oxidation and acid corrosion, typical of internal combustion engines, are non-existent in the Stirling engine. No failure modes are identified at this time, except bearing wear-out, which is materials-dependent. Bearings have been selected for a life time that is estimated to be in excess of $30,000 \mathrm{~h}$. Further failure mode analysis may be valuable here.

The design 1ifetime goal for the ASE Mod II is $3500 \mathrm{hr}$. It is expected that engine maintenance or overhaul will be virtually eliminated for this period of time. Even at this lifetime, however, maintenance costs will be high for the solar application. Additional design is needed to increase lifetime by an order of magnitude. Heater head temperature is dropped to $720^{\circ} \mathrm{C}$ and design life is increased to 16,000 hr (Appendix A). Seals and piston rings, however, are presently estimated on the conservative side at $6000 \mathrm{~h}$, requiring minor overhaul at 1.5-to-2-yr intervals. On this basis, per-engine maintenance costs are estimated at roughly $\$ 1500 / y r$ or more.

Scaling of the ASE/United Stirling AB technology to higher power levels is available. The 4-95 is a prototype technology for the 75-kW 4-275 engine at United Stirling $A B(60 \mathrm{~kW}$ at $1800 \mathrm{rpm})$. That engine is also being developed in Sweden in V-crank configuration. In addition, two 4-275 engines have been operated together on a single shaft as a 150-kW, 8-cylinder Stirling engine. Al1 United Stirling and subsidiary engines are subject to an exclusive solar license agreement with McDonnell Douglas Astronautics Corporation, Huntington Beach, California. 
In Summary: The United Stirling $A B$ engine family is now in the process of commercialization for the solar application. The automotive program has emphasized development to 3500-hr MTBO and easy maintainability. Improvement is now needed, as was shown in Section II.C. to increase the MTBO to at least $3 \times 10^{4}$ hours. The high reflectance losses and relatively large $\Delta \mathrm{T}$ in the receiver heat exchanger are undesirable. A new heater head should be provided for long 1 ife at $800^{\circ} \mathrm{C}$ and should include heat pipe operation. United Stirling should be encouraged to make this final step in the solarization of their engines.

\section{Societe' ECA, Meudon, France}

Based on studies commencing in 1975, ECA, in conjunction with the French Nuclear Research Center (C.E.N.G.) in Grenoble, has built a heat pipe Stirling engine for underwater propulsion. Heated by stored thermal energy from phase change salts, the system has been in operation since January 1984 . Engine testing has been in progress since 1982.

The ECA engine (see Figure 1-2) makes several advances from the United Stirling engine. First, the heater is optimally designed for condensing heat transfer with sodium heat pipes. Second, the four-cylinder double-acting engine (4-113) operates from a simple in-line-geometry crankshaft. This operation ideally balances all variations in torque and very closely approaches the present automotive crankcase design. Third, the pressurization system produces a reduced-pressure environment for the Leningrader seals, while extra seal redundancy is also provided. While this seal system requires additional lifetime testing, there appears to be considerable promise in the approach. Piston ring 1 ifetime in excess of $30,000 \mathrm{hr}$ is expected if seals remain intact. Optimization of heaters, coolers, and regenerators is yet to be accomplished, where the present $36 \%$ peak brake efficiency will shortly be boosted to approximately $40 \%$ at a heat pipe input temperature of $720^{\circ} \mathrm{C}$. Power output at $1200 \mathrm{rpm}$ is approximately 12 to $15 \mathrm{~kW}$ (Reference 13), and at $1800 \mathrm{rpm}$ will become $22 \mathrm{~kW}$. Engine weight, with aluminum technology, will be 100 to $130 \mathrm{~kg}$.

Because of the heat pipe thermal input, it is possible to operate on a solar dish without inverting the Stirling engine. Thus, engine modification may not be necessary for the solar application. However, for $50 \%$ operating efficiency with $820^{\circ} \mathrm{C}$ heat pipes, it will become necessary to provide partially stabilized zirconia (PSZ) coatings on the cylinder to maintain long 1ife. The PSZ technology has been developing for the adiabatic diesel engine (Reference 14) and should be tested with the Stirling engine.

Scaling of the engine to larger power levels is very straightforward. The present engine uses the smallest available automotive crankcase from Renault. Power levels of $250 \mathrm{~kW}$ or even greater are probable. Minor modification of an automotive crankcase is required, matched to a scaled-up Stirling cycle. Production cost of the in-line-four engine should be extremely low. However, ECA is in the submersibles business only and would look to outside companies to design and produce a solar engine.

In Summary: The ECA Stirling engine is definitely identified as an alternative candidate for the solar application. Prototype testing at C.E.N.G. should be carefully and continuously monitored to evaluate the 
performance and reliability/life of this advanced technology. Present tests will need to show long seal $\mathrm{life}$ and a performance in excess of $40 \%$ engine efficiency.

If successful in these tests, further development of PSZ ceramic coatings and a test program at $820^{\circ} \mathrm{C}$ should be recommended. Possibilities of operation at $3600 \mathrm{rpm}$ at a higher power level should be explored.

3. Stirling Thermal Motors, Inc., Ann Arbor, Michigan

STM is developing a 4-120 variable swashplate Stirling engine (see Figure 1-3). A working diagram of the swashplate stirling engine is shown in Figure 3-3. The rotating swashplate on the engine main shaft is driven by four double-acting pistons through hydrodynamic bearings in the crossheads. The hot working space of one cylinder interacts through a heater, regenerator, and cooler into the cold working space of the next cylinder. Operating from a heat pipe thermal input, the engine is rated at $40 \mathrm{~kW}$ at $3000 \mathrm{rpm}$. Recently, B. V. Stirling Motors Europe has been licensed by STM for the production and marketing of this engine in Europe. At $1800 \mathrm{rpm}$ and $11 \mathrm{MPa}$, the engine will develop approximately $27 \mathrm{~kW}$. According to STM, at 25,000 units/yr, engine cost has been estimated by Pioneer Engineering at $\$ 1150$. The price, including capitalization, should be approximately double the cost. As a solar (or other) market develops in the United States, production facilities will be built by STM (or licensed) in this country.

The swashplate engine has the minimum number of moving parts for a kinematic stirling engine. It is operated at constant pressure and variable stroke, thus maintaining high efficiency at much lower power level than the conventional Stirling machine. Efficiency remains almost constant to half power, and thereafter falls only gradually until approximately $10 \%$ of full power. The engine is also very compact and lightweight. Engine mass is presently estimated at $80 \mathrm{~kg}$, excluding auxiliaries.

The entire engine is to be sealed, with its driveshaft penetrating through an aircraft-type rotating seal. The crankcase is also pressurized. The main piston-rod seal thus sees no mean pressure differential. The working gas is helium which serves to maintain hermeticity. Operating at a constant mean pressure, the engine controls will be greatly simplified and may rapidly respond to external requirements.

The heater for the STM engine will use sodium heat pipes with condensing heat transfer. The heater tubes are configured for minimum dead volume. At approximately 800 to $820^{\circ} \mathrm{C}$ heater temperature, engine efficiency is calculated at 48 to $50 \%$. Life of the heater head is in excess of $100,000 \mathrm{hr}$. Heat pipes have been tested for $10,000 \mathrm{hr}$ thus far.

The engine will produce $17 \mathrm{~kW}$ of power at a mean pressure of $7 \mathrm{MPa}$. If pressure is increased to $13 \mathrm{MPa}$, and speed is increased to $3600 \mathrm{rpm}$, power output is $55 \mathrm{~kW}$. To maintain extended lifetime at high power level, the present shaft bearings will be changed to hydrodynamic bearings, while thrust bearings will be doubled. Engine efficiency, with these changes, will drop by approximately one percentage point, while life is extended beyond $100,000 \mathrm{hr}$ at $25-\mathrm{kWe}$ power. At $25-\mathrm{kW}$ power output, present bearing lifetime will be 20,000 to $30,000 \mathrm{hr}$. 


\section{ORIGINAL PAGE IS \\ OF POOR QUALITY}

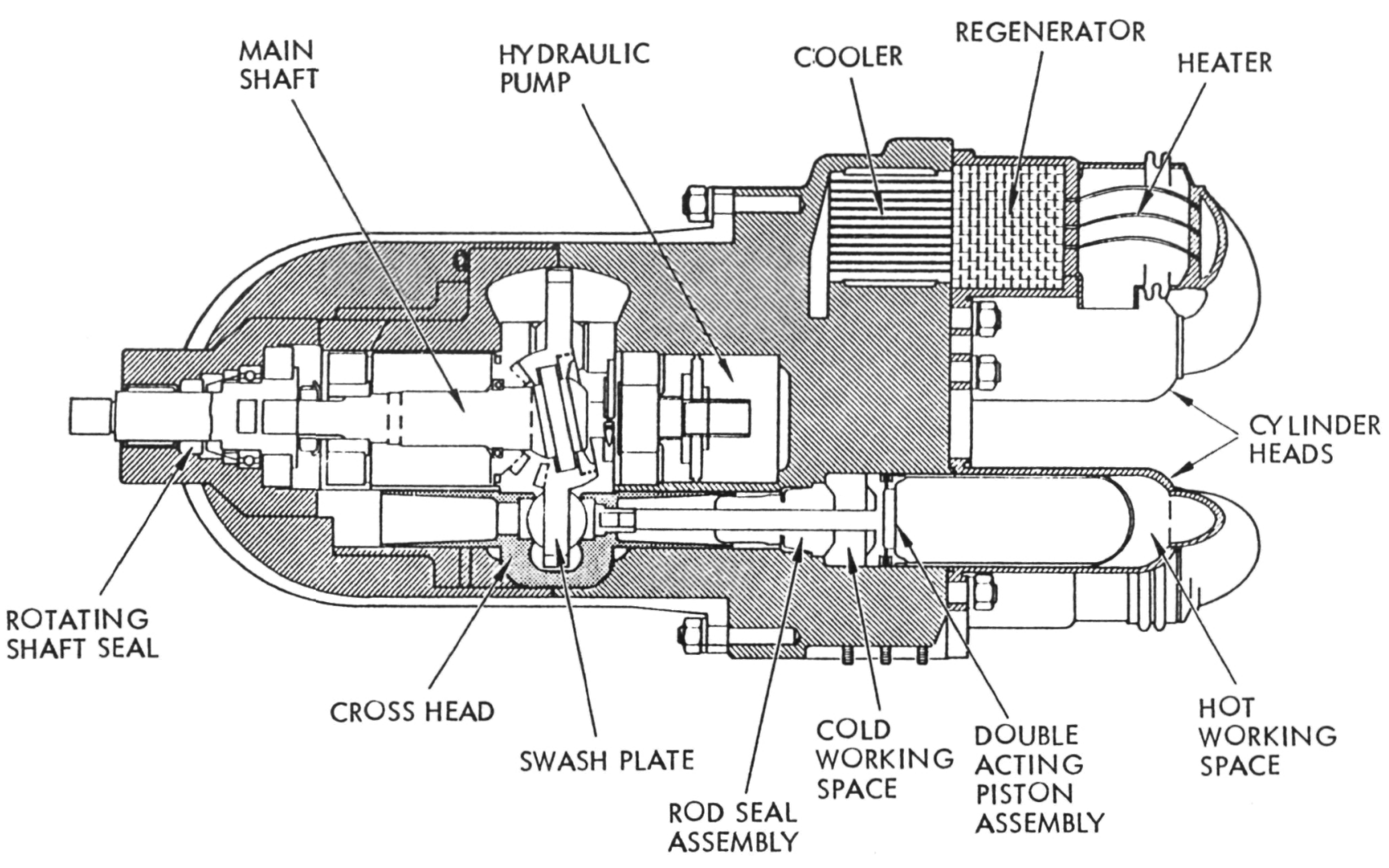

Figure 3-3. Variable Swashplate Stirling Engine Working Diagram 
A new rod seal with a compliant housing, capable of rapidly following the rod lateral motion, is being tested. In the test rig, a large (100-m) crosshead clearance has been introduced, and the piston has been removed besides. In spite of these exceptionally large tolerances introduced, the seal is presently operating dry as running time approaches $10,000 \mathrm{hr}$. Test conditions are at least an order of magnitude worse than would be seen in an operating engine. Piston ring tests have been run in the Netherlands on a rhombic drive engine and showed very low wear, with lifetime extrapolated to possibly 100,000 hr (Appendix B). Advanced piston rings are now in test at STM. Test rig data are thus far very encouraging, and testing is planned to continue until at least $10,000 \mathrm{hr}$.

In Summary: The variable swashplate Stirling engine is an important alternative candidate for the solar application. The engine is presently in prototype fabrication and assembly, with five engines to be built and tested. Cold testing of the initial prototype should be completed by the end of CY 1985. Initial hot testing will follow. The test results are expected to confirm the STM design analysis. Initial testing should then be followed by a 10,000-hr endurance test. If possible, engine modification and test at $3600 \mathrm{rpm}$ should be supported. Data on performance, durability, and producibility are needed prior to the planning of quantity production.

\section{B. FREE PISTON STIRLING ENGINES}

The free piston Stirling engine (FPSE), initially developed by Dr. William Beale of Sunpower, Inc., in Athens, Ohio, is receiving considerable development attention at MTI and Energy Research and Generation, Inc. as we11. The FPSE is a totally enclosed machine that oscillates when a heat source and heat sink are applied. The working piston and displacer are the primary components of two interacting spring-mass systems as seen in Figure 3-4. The engine uses gas-bearing suspension. Because of frequent on-off duty cycling of the solar application, a hydrodynamic gas bearing is probably needed. Such a bearing is currently in development.

Typically, a permanent magnet linear alternator is attached to the power piston for single phase ac output. At present, control of phase angle between the displacer and power piston is somewhat limited, thereby limiting the efficiency of the engine. However, because kinematic losses are eliminated in the FPSE, efficiency is almost equal that achievable by kinematic machines. Very close clearances $(\sim 25 \mu \mathrm{m})$ are required for the gas bearings, also essential to keeping blow-by losses low for high efficiency. There is virtually no wear of components and, with only two moving parts in the FPSE, the machine has an inherent high reliability and lifetime.

\section{Mechanical Technology, Inc., Latham, New York}

An advanced 25-kWe FPSE development for space power application (Figure 3-5) (Reference 2) is in progress at MTI, with a planned lifetime of $60,000 \mathrm{hr}$. Scaling is being done more or less based on the $3 \mathrm{kWe}$ power level of a previous engineering model endurance test engine program, privately funded (Reference 15). The $25-\mathrm{kWe}$ power output is provided by two identical 12.5-kW power level submodules in an opposed, dynamically balanced in-1ine 


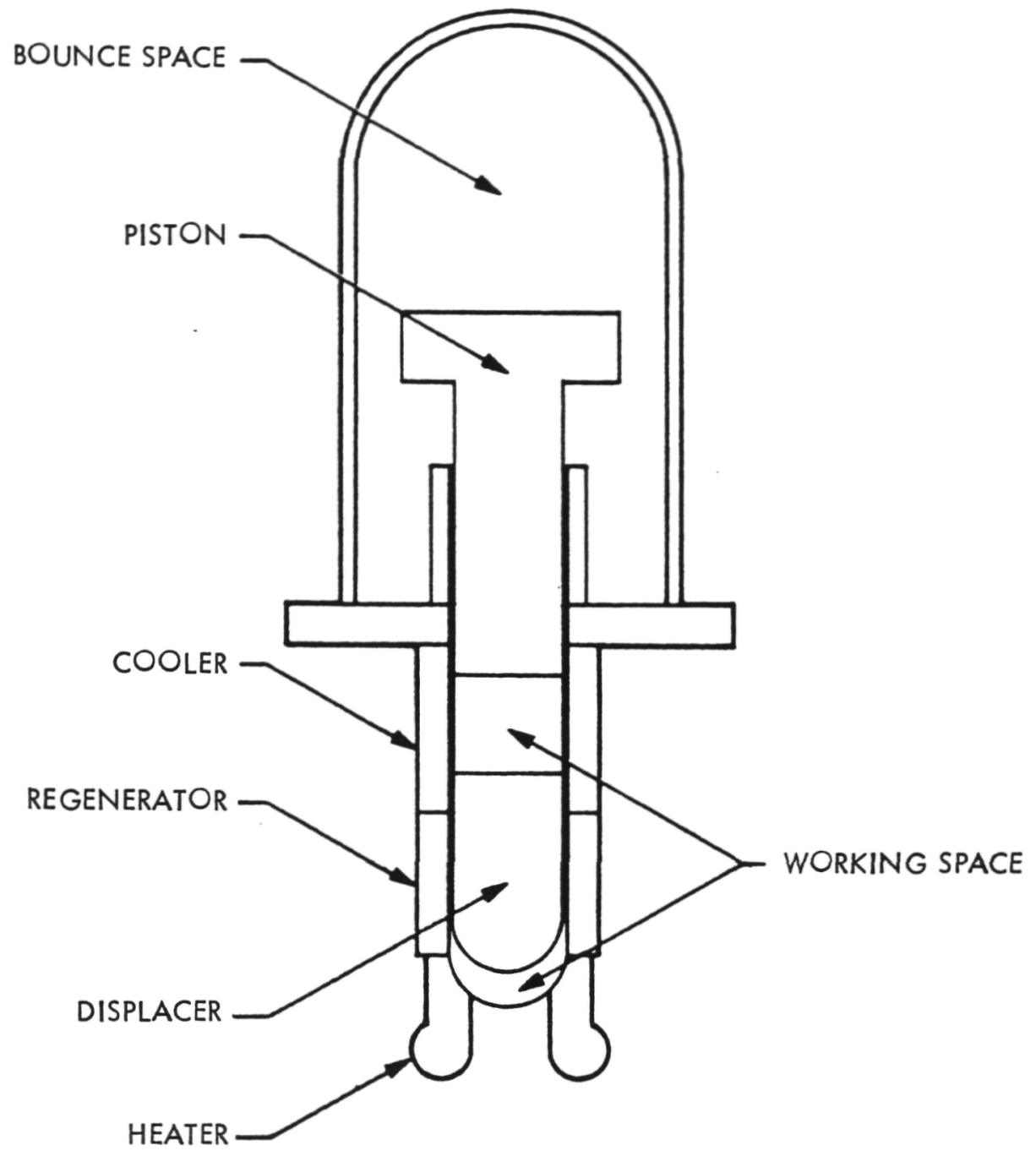

Figure 3-4. Free Piston Stirling Engine Elementary Concept

configuration with helium as the working gas. Operation is to be at a constant power level at $105 \mathrm{~Hz}$ and with a heater head temperature of $800^{\circ} \mathrm{C}$ or less. To achieve minimum weight, parts of the machine are fabricated of beryllium, titanium, and samarium cobalt. Where weight is not critical, these parts can be redesigned to lower the cost.

The heater tubes (tube-in-shel1) stacked-screen regenerator and cooler (also tube-in-she11) are annular to the displacer. The permanent magnet alternator is of the moving magnet design, operating between an inner and outer laminated Hyperco stator. Containment is within a high-strength steel pressure vessel. Water cooling has been provided in an initial test engine design called a "Space Power Demonstrator Engine Design" (Reference 2). The heater appears adaptable to heat pipe input rather than salt, although brazed joint compatibility needs to be examined. 


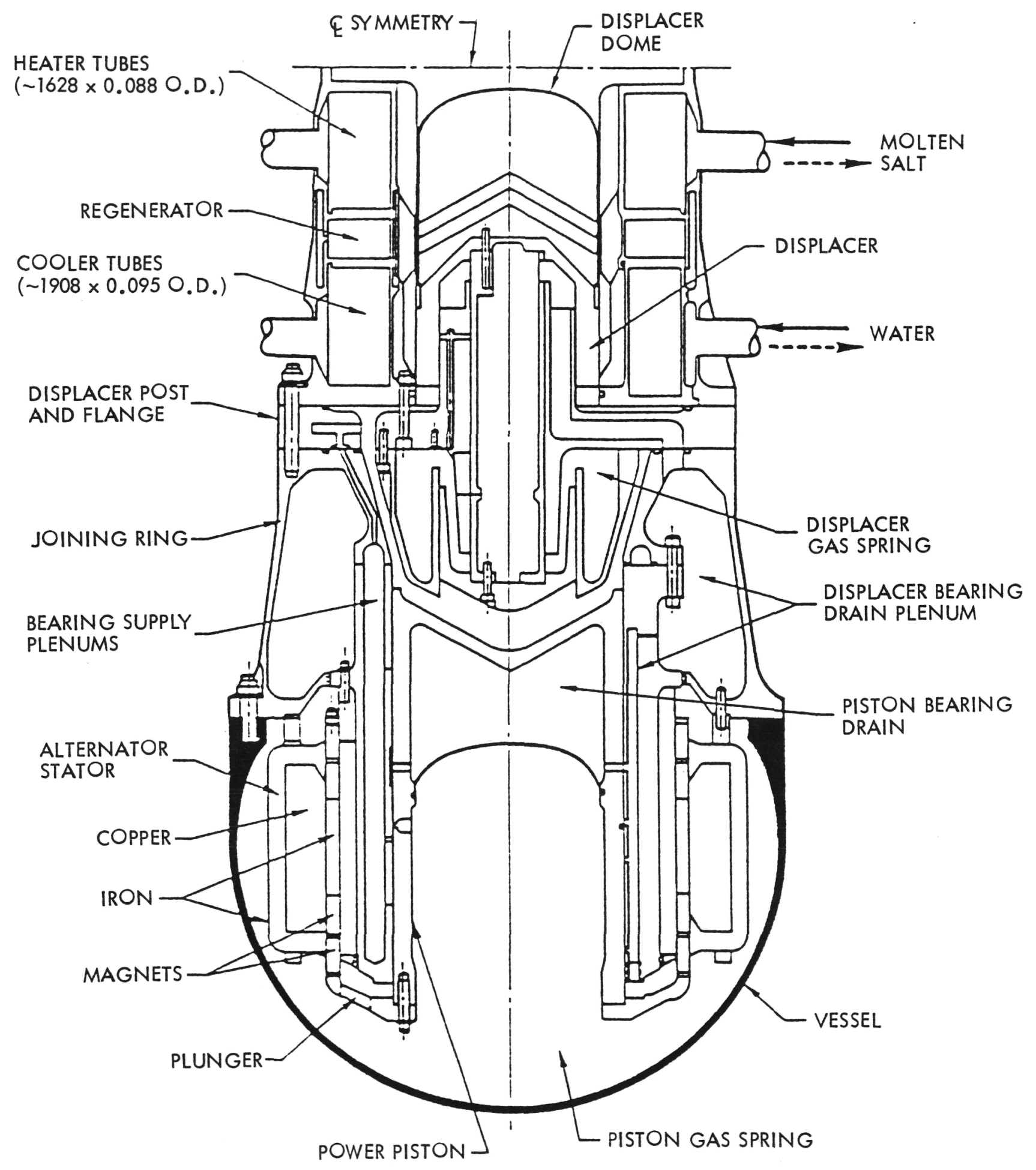

Figure 3-5. 25-kWe Free Piston Stirling Engine Space Power Demonstrator Engine 
The Space Power Demonstrator Engine is to be built and tested at a heater temperature of $357^{\circ} \mathrm{C}$ and a cooling temperature of $42^{\circ} \mathrm{C}\left(\mathrm{T}_{\mathrm{H}} / \mathrm{T}_{\mathrm{C}}=2.0\right)$

to verify the preliminary design. Performance expectation for solar is shown in Figure 3-6. The opposed engine design by MTI may prove out better in performance than previous opposed-piston operation has shown, but preliminary testing has only just started. Hydrodynamic bearings need to be added. The dynamically balanced design is considered necessary because of the significant vibration of a non-balanced single engine. Output electrical power is single phase, ac. Scaling of the FPSE to power levels above $25 \mathrm{kWe}$ will be quite difficult. The diameter of machines will increase and the stroke will be shortened.

In Summary: The MTI free-piston machines can become alternative candidates for the solar application, provided that significant increases of efficiency and power level can be demonstrated in a low-cost, durable design. Several developments appear to be needed. Controls must be introduced to allow the optimization of phase angle and stroke on the displacer and the increase of pressure ratio in the engine. Complete isothermalization should be developed. Fully-integrated multiple engines/pistons are needed for three-phase power generation at high performance and high power output. Ceramic technology and/or reduced mean operating pressure in the heater head may be needed to allow the operation at $800^{\circ} \mathrm{C}$ and above. With these developments, high durability of the free-piston technology must also be maintained. Producibility will also require reevaluation.

2. Sunpower, Inc., Athens, Ohio

An alternative 25-kWe power level free-piston Stirling engine is being designed by Sunpower. A single, dynamically balanced engine is proposed. Early work at Sunpower with opposed machines was not considered satisfactory. Basic operation of the Sunpower engine is quite similar to the MTI engine. Working gas pressure is at $20 \mathrm{MPa}$ to keep mass down, and frequency is set at $90 \mathrm{~Hz}$. The vibration damper introduces a 5 to $12 \%$ mass increase and operates at about 2-mm amplitude.

Sunpower is proposing a spun hydrodynamic gas bearing. The spin bearing is being built and tested in FY 1985. Analysis has also shown a method of obtaining three-phase power output from the FPSE. For the solar application, an engine might be designed and built in approximately 2 to $21 / 2 \mathrm{yr}$. Efficiency of the free piston machine is approaching $40 \%$, and could be increased approximately 10 points by converting to hydrogen as the working gas (Reference 16). Scaling of the FPSE to higher power levels may be possible, but efficiency may fall. Gas plenums become very wide and losses increase. The optimum power level for a single unit is estimated at approximately $20 \mathrm{kWe}$.

In Summary: The Sunpower free-piston machines can become alternative candidates for the solar application, provided that significant increases of efficiency and power level can be demonstrated in a low-cost, durable design. Several developments appear to be needed. Controls must be introduced to allow the optimization of phase angle and stroke on the displacer and the increase of pressure ratio in the engine. Complete isothermalization should be developed. Fully integrated multiple engines/pistons are needed for 


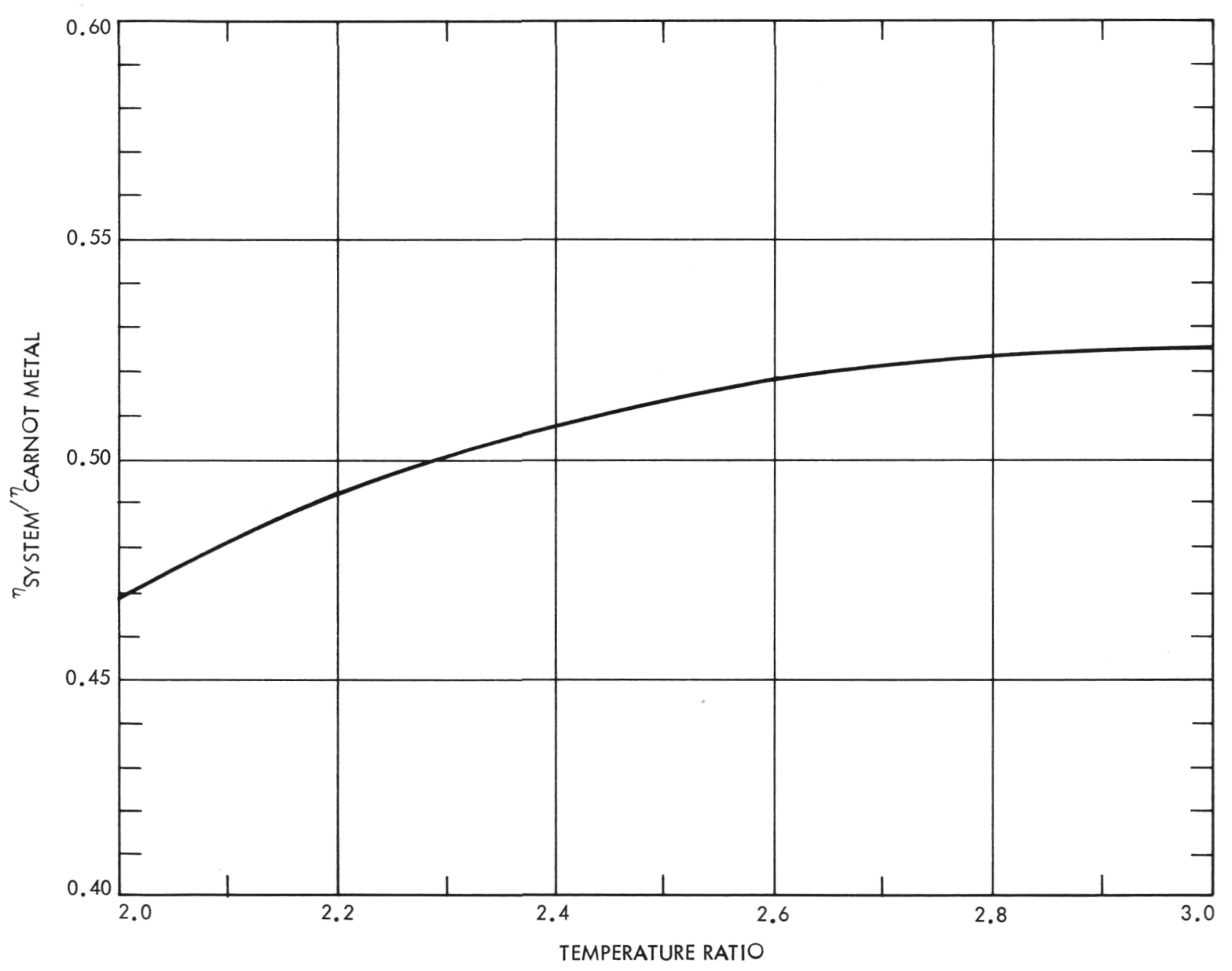

Figure 3-6. Solarized Space Power Demonstrator Engine Efficiency 


\section{ORIGINAL PAGE IS \\ OF POOR QUALITY}

three-phase power generation at high performance and high power output. Ceramic tecinnology and/or reduced mean operating pressure in the heater head may be needed to allow the operation at $800^{\circ} \mathrm{C}$ and above. With these developments, high durability of the free-piston technology must also be maintained. Producibility will also require reevaluation.

3. Energy Research and Generation, Inc., Oakland, California

ERG, under contract to JPL in 1979 and 1980, developed an analysis and preliminary design for a 15-kWe free-piston Stirling engine. This design (Figure 3-7) was presented in 1980 in the 15th IECEC Proceedings (Reference 17). Test results of high-efficiency components were presented in 1982 in the 17th IECEC Proceedings (Reference 18).
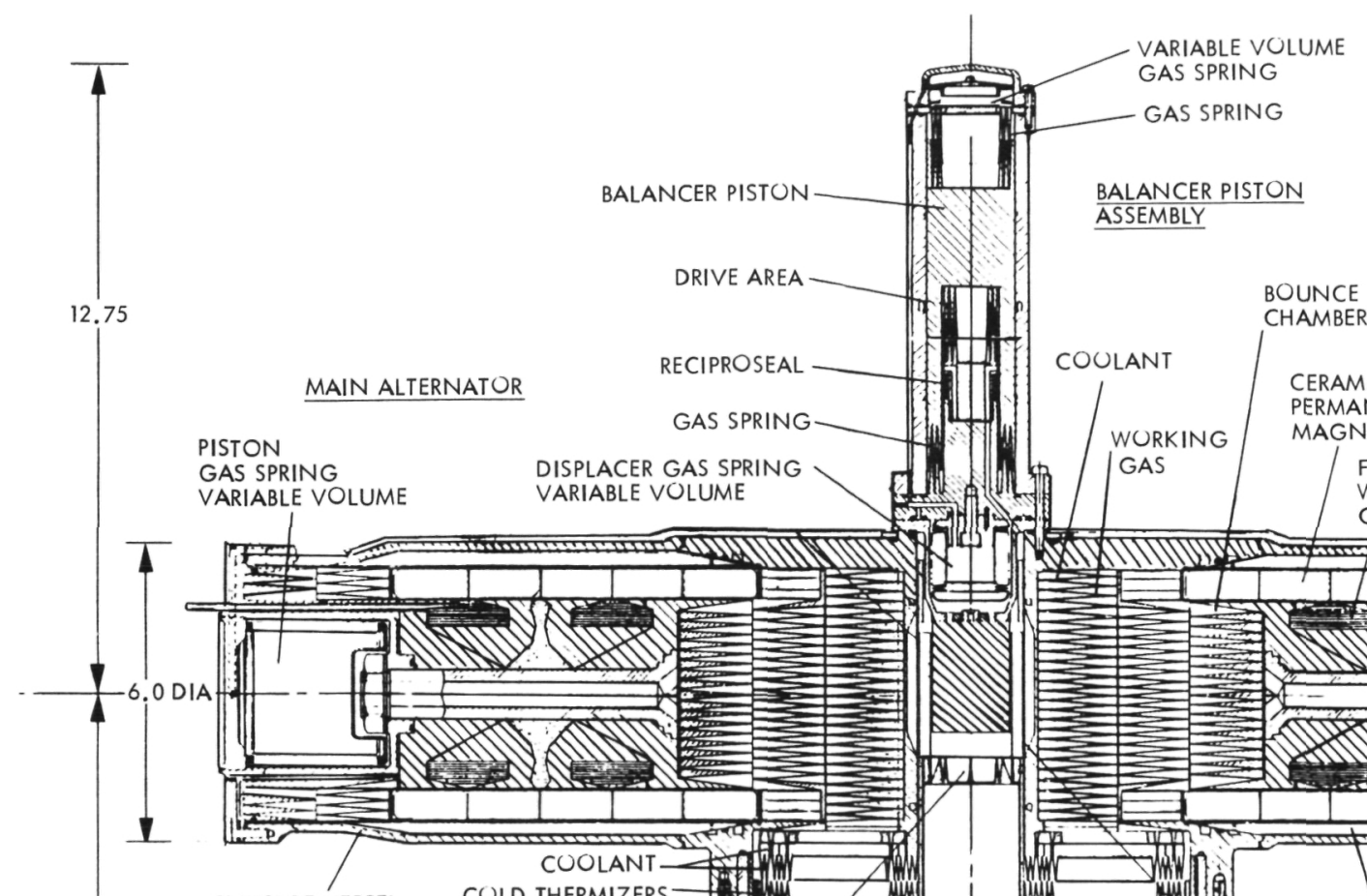

PRESSURE VESSEL

COLD THERMIZERS CULD GAS SPRING DRIVE AREA — ASSEMBLY
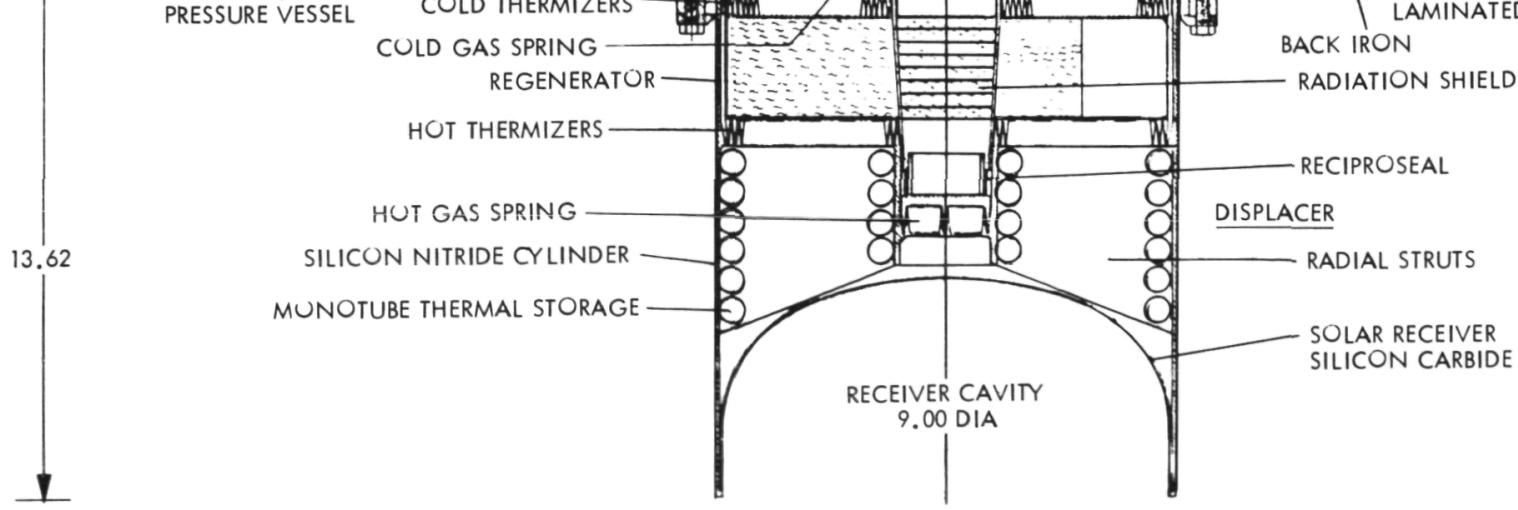

Figure 3-7. Detail of the 23-kW Free Piston Stirling Engine 
The work at ERG is quite advanced. Overall PCU thermal-to-electric conversion efficiency greater than $60 \%$ is predicted. Ceramic hot parts with a heat pipe receiver are defined, operating at $1000^{\circ} \mathrm{C}$. Displacer stroke and phase angle control are added and isothermalized variable volume chambers are developed that may produce up to $90 \%$ of Carnot efficiency. Regenerator design is optimized. An advanced generator was defined, and has subsequently (in 1984) tested at an efficiency approaching 99\% (Reference 19).

The engine design uses a single displacer with a balancer piston assembly and two opposed working pistons. This arrangement has not been tested as an entire assembly. However, the opposed pistons have been operated in a driven test rig so that their characteristics could be analyzed in detail. If this configuration can be proven, scaling to power levels of 50 to $75 \mathrm{kWe}$ may not be a major problem, according to ERG. Design, fabrication, and test of a complete prototype solar subsystem may require 3 to $4 \mathrm{yr}$.

In Summary: The ERG free-piston Stirling engine is considered as an alternative candidate for the solar application. Features not yet included in other engine designs have been pursued by ERG in preliminary design and component tests. An engineering model engine, however, has not been built. Such an engine would be extremely valuable as a demonstration of the advanced technology and should be proposed.

\section{RINGBOM STIRLING ENGINES}

A Ringbom engine is a hybrid Stirling engine with a free displacer and a crank-operated piston. Its primary advantages over the full kinematic Stirling are its mechanical simplicity and improved thermodynamic cycle. G. Walker (Reference 20) of the University of Calgary, Alberta, Canada, and J. R. Senft (Reference 21) of the University of Wisconsin are pioneers of this unusual concept, described in Figures 3-8 through 3-11, and Table 3-1.

Most recently, the University of Washington Joint Center for Graduate Study (JCGS) team in Richland, WA, which is developing an implantable artificial heart power source with Cleveland Hospital (Reference 22), has begun development of a 200-W "hydrokinematic" engine. The work is considered proprietary, but is an evident offshoot of the hydraulic Stirling, free-piston, free-displacer work for artificial heart power. The hydrokinematic engine uses a free displacer with a power bellows, while the converter piston and drive piston are now crank-operated. Dr. Senft was a consultant during the engine design.

An impressive body of life test data has been gathered by JCGS for pressure balance welded metal bellows (Reference 23). Crankcase efficiency for the hydrokinematic engine is estimated at $92 \%$ or better. Several concepts have been identified for finely balanced double-piston space power application. Dual-alternator power output of 25 to $30 \mathrm{kWe}$ has been indicated. Scaling to even higher power levels appears to be available.

Test of the 200-W-power JCGS engine is scheduled in FY 1985. An independent test of a fuel-fired combustor is currently in progress. Depending on the results of early engine tests, follow-on development of much larger engines may become desirable. 


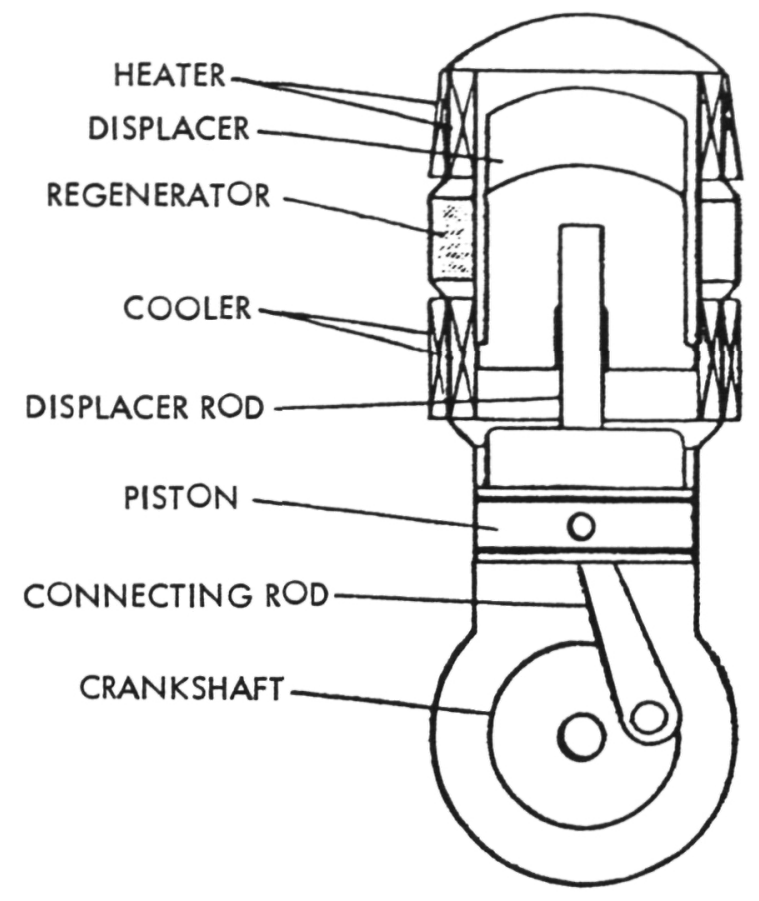

Figure 3-8. The Elementary Single-Cylinder Ringbom Engine Concept

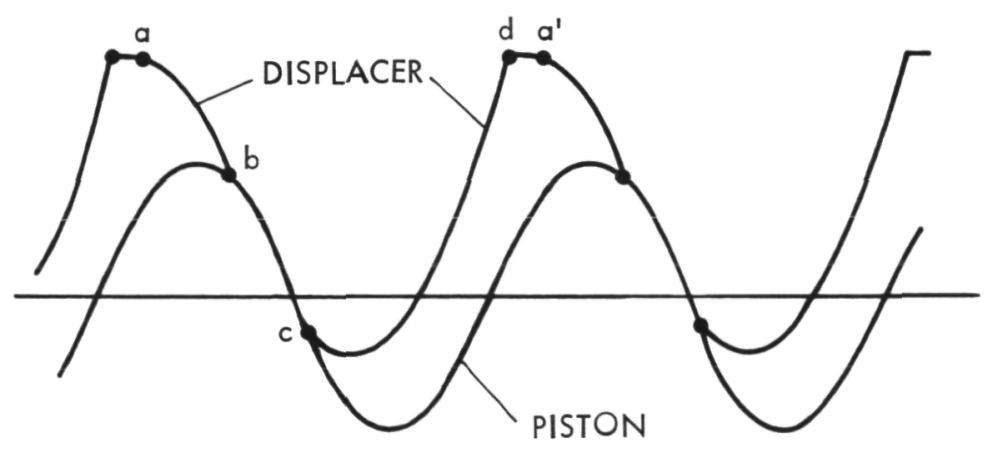

Figure 3-9. Steady-State Operation of a Single-Cylinder Ringbom with Displacer Stops on the Piston and at the Hot End 


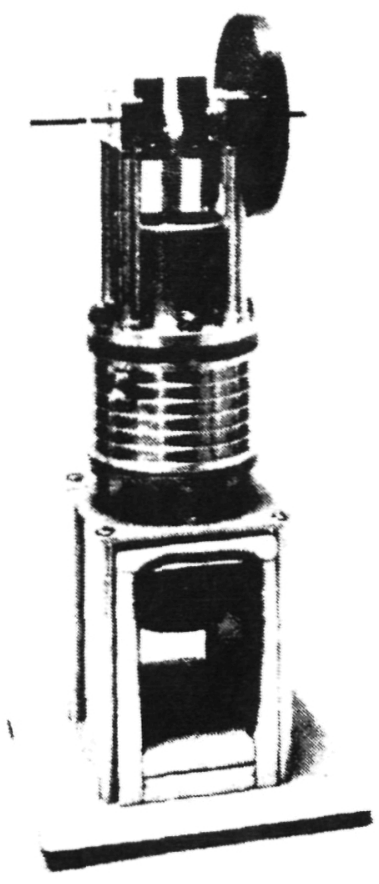

Figure 3-10. Small Single-Cylinder Ringbom Built at the University of Wisconsin

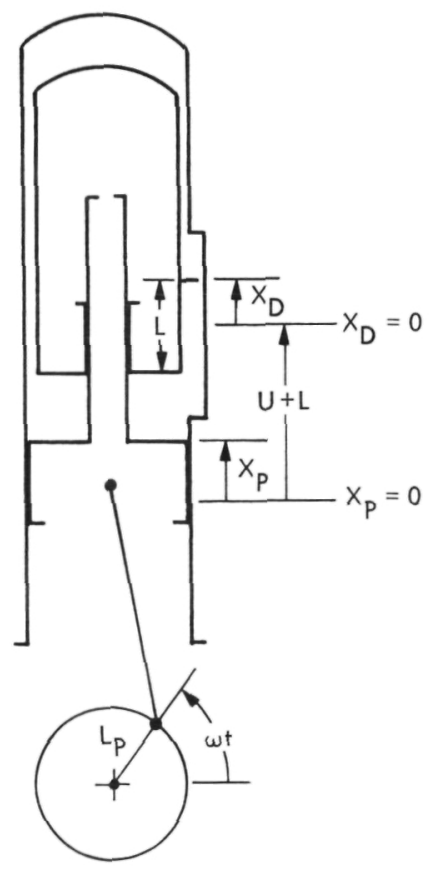

Figure 3-11. Schematic Drawing of a Single-Cylinder Ringbom with Absolute Displacer Stops at the Hot and the Cold Ends 
Table 3-1. Modeling Assumptions

1. Each of the three spaces within the engine is isothermal in space and time.

2. Instantaneous pressure is spatially constant.

3. The working fluid is an ideal gas.

4. The mass of working fluid in the engine is constant.

5. External gas pressure is constant and equal to internal midstroke pressure.

6. Displacer motion is physically limited by totally rigid stops.

7. Other than that provided by the stops, the only force acting on the displacer is that due internal and external pressure difference across the displacer rod.

8. Displacer collisions are totally inelastic.

9. Piston motion is sinusoidal. 
1. Vincent, R., Rifkin, W., and Benson, G., "Analysis and Design of FPSE Thermodynamics and Dynamics," Proceedings of the 15th IECEC, 1980.

2. Dochat, G. R., "Free Piston Stirling Engines for Space Power," Proceedings of the 22nd Automotive Technology Development Contractors' Coordination Meeting, Dearborn, Michigan, October 1984 .

3. Fujita, T., Manvi, R., El Gabalawi, N., Herrera, G., Kuo, T., and Chen, K., Techno-Economic Projections for Advanced Sinall Solar Thermal Electric Power Plants to Years 1990-2000, JPL Publication 79-25, Jet Propulsion Laboratory, Pasadena, California November 1978.

4. United Stirling (Sweden), Design Study of a Kinematic Stirling Engine for Dispersed Solar Electric Power Systems, Report No. DOE/NASA/ $0056-79 / 2,1980$.

5. Stine, W. B., Survey of Manufacturers of High-Performance Heat Engines Adaptable to Solar Applications, JPL Publication 84-46, Jet Propulsion Laboratory, Pasadena, California, June 1984.

6. Nakatani, Y., Mori, H., Narimatsu, Y., and Watanbe, T., "Stirling Engine Development Project in Japan," Proceedings of the 19th IECEC, August 1984.

7. Meijer, R., "The Philips Hot-Gas Engine with Rhombic Drive Mechanism," Philips Technical Review, No. 20, 1958, pp. 245-262.

8. Van Weenan, F. L., "The Construction of the Philips Air Engine," Philips Technical Review, No. 9, 1947, pp. 125-134.

9. Stearns, J. W., and Haglund, R., "High Performance Solar Stirling System," AIAA Paper 81-2554, December 1981.

10. Corey, J. et a1, "Design Description of an Automotive Stirling Engine with a Competitive Manufacturing Cost," Proceedings of the 22nd Automotive Technology Development Contractors' Coordination Meeting, Dearborn, Michigan, October 1984.

11. Lundholm, G., "Statistical Life Testing of Stirling Engine Main Seals," Proceedings of the 21st Automotive Technology Development Contractors " Coordination Meeting, Dearborn, Michigan, November 1983.

12. Ernst, W. D., "Mod II Engine and Technology Development," Proceedings of the 19th IECEC, August 1984. 
13. Alleau, T., Bricard A., Chabanne J., Carlqvist, S.G., Cucroux, P., and A. Thouvenin, "The CEA-ECA Stirling Cycle Energy Conversion System, A Review of Test and Development Status," Proceedings of the 19th IECEC, August 1984.

14. Larsen, D. C., and Adams, J. W., "Long-Term Stability and Properties of Partially Stabilized Zirconia," Proceedings of the 22nd Automotive Technology Development Contractors Coordination Meeting, Dearborn, Michigan, October 1984.

15. Dochat, G. R., "Free Piston Stirling Engine Endurance Test Program," Proceedings of the 21st Automotive Technology Development Contractors Coordination Meeting, Dearborn, Michigan, November 1983.

16. Berchowitz, D., Sunpower, Inc., private communication, November 7, 1984.

17. Benson, G., Rifkin, W., and Vincent, R., "An Advanced $15 \mathrm{~kW}$ Solar Powered Free Piston Stirling Engine, Proceedings of the 15th IECEC, August 1980.

18. Vincent, R., Rifkin, W., and Benson, G., "Test Results of High Efficiency Stirling Machine Components," Proceedings of the 17 th IECEC, August 1982.

19. Slaby, J. G., "Overview of NASA Lewis Research Center Free-Piston Stirling Engine Activities," Proceedings of the 19th IECEC, August 1984.

20. Walker, G., Stirling Cycle Machines, Clarendon Press, Oxford, 1973.

21. Senft, J. R., "A Mathematical Model for Single-Cylinder Ringbom Stirling Engines," Proceedings of the 19th IECEC, August 1984.

22. White, M. A., "Miniature Stirling Engines for Artificial Heart Power," Proceedings of the 18th IECEC, August 1983.

23. White, M. A., Emigh, S. G., Gray, D. H., Krogness, J. C., Noble, J. E., Olan, R. W., Oster, J. F., and Riggle, P., "Hermetic Metal Seals for Stirling Engines," Proceedings of the 19th IECEC, August 1984. 
APPENDIX A

LIFE AND MAINTENANCE REQUIREMENTS, UNITED STIRLING AB 


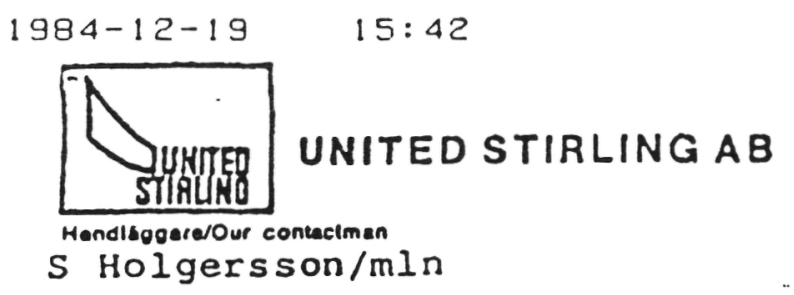

$\mathrm{S}$ Holgersson/min

Datumsoate December 19, 1984

En detumyour date

Es relereneryour reference

Jet Propulsion Laboratory

Attention: Mr J Stearns, Mail Stop 510-2

4800 Oak Grove Drive

PASADENA, CALIFORNIA 91109

USA

Gentlemen:

It has come to our knowledge that a final summary of the work done over the previous years by JPL within the parabolic dish project is being prepared. During discussions with JPI we have understood that the background material used by JPL needs updating. Figures for life and $O$ \& $M$ for the stirling engine reflect the early prototype design. when the original development model of the 4-95 USAB stirling engine was used. That engine was converted by means of adapting equipment on the existing design to meet the requirements for installation in a parabolic dish system.

Also the solar stirling engine is often compared to the automotive Stirling engine developed by USAB under a subcontract by MTI and NASA (DOE), which gives inaccurate conclusions. The two stirling engines include of course many similar components but first the basic design criteria such as design life, operation characteristics, parameter optimization etc are different, and second the operation of the engines is quite different with respect to transients, load spectra etc. The above differences will give quite different results for life and maintenance for components. We would therefore like to convey our views on the solar engine status to you.

Today's solar stirling engine has been specially designed to meet the application requirements and improvements of components have been made due to better knowledge of operation parameters in the application. Also production cost and maintenance operations have been much more integrated into the design to meet commercial requirements. This gene-ration of stirling engine with receiver and subsystems as generator, electrical switchbox, controller and radiator system creating a selfsustaining power conversion unit is quite different from the earlier prototype system. 
UNITED STIRLING AB

Jet Propulsion Laboratory

Attention: Mr J Stearns, Mail Stop 510-2

Page 2

Today's engines are tested both in its application in a parabolic dish and also separately in forced laboratory testing simulating the application with respect to load, transients etc. During the latest years a number of engines have undergone testing and we have developed a broad base for estimation of component life. Also during the latest years we have had a break through in. the development of some components, which has increased the life and MTBF of the total engine significantly. From the ongoing laboratory testing in Sweden, where many more operating hours can be accumulated than in a real application, can be mentioned that several number of tests with piston rings used in more than 3000 hours without failure or performance degradation have been carried out, that failure of a piston rod seal is very rare and that heater failure is very rare (even heater failure in real solar application is very rare if failures at Edwards Air Force Base with burned receivers as a consequence of other problems, mainly human errors, are excluded).

The basic parameters to be used for the $O \& M$ evaluation are life for the complete engine, heater life, piston ring and piston rod seal life.

The design life for the mature complete engine is 20 years with a yearly operation of 2500-3000 hours per year. The 20 year life includes two major overhauls, where most of the moving parts are exchanged, however, the basic structural components can be used over the whole life period.

The design life for the mature receiver is 16000 hours, which will mean an exchange of heater two times over the system life.

The life for piston rings and piston rod seals is 3000-4000 hours, which will result in a periodic service once a year for exchange of these components.

In addition to the planned maintenance it is realistic to anticipate that minor failures which can easily be corrected without removal of the engine from the dish will occur. One example of such a failure is malfunction of the control electronics which can be corrected by switching a circuit board. The projected meantime between such type of failures is in the order of 1000 hours. 


\section{APPENDIX B}

LIFE AND MAINTENANCE REQUIREMENTS, STIRLING THERMAL MOTORS, INC. 


\title{
STIRLING THERMAL MOTORS, INC.
}

\author{
EXECUTIVE OFFICES
}

November 27,1984

Mr. John W. Stearns, Jr.

Je $\imath$ Propulsion Laboratory

4800 Oak Grove Drive

Pasadena, CA 91109

Dear Jack:

Please find enclosed the summary, conclusions and interpretation of a long term (10,000 hour) endurance test that was conducted by N.V. Philips. The enclosure only addresses the piston ring issue and includes the application of the results to our BTSE engine.

I hope that this information (which is perhaps contrary to some recent experience at USS and MTI) will help raise the confidence level in the life potential of current technology piston rings.

In addition, please be aware that this is, by no means, the only endurance data generated by Philips. Many other tests were conducted and they clearly corroborate the conclusion that a steady state wear rate of 4-6 $\mu \mathrm{m} / 1000$ hours is cractically achievable. Unfortunately, we do not have documentary evidence of these tests.

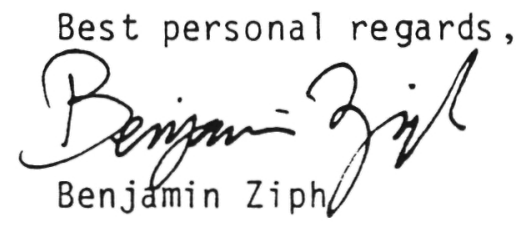

$\mathrm{BZ} / \mathrm{CCW}$

Enclosure 


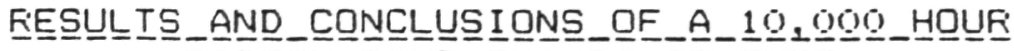 EIISION_EIING_ENDUEFANCEE_TESI}

Between October 1969 and December 1971 N.V. Finilips conducted an endurance test of a $1-98$ Stirling engine. The results of this test, where 10,000 hours of running time were accumulated, were documented in two proprietary internal reports (numbers 4502 and 4643 ). The following is a summary of the results regarding the wear of the displacer rings. Such results are directly applicable to the piston rings in a double acting engine as shown in Figure 1. The history of the displacer ring during the 10,000 hour test is shown in Figure 2.

Upon start up the ring exhibited a high wear rate during the first 100 hours while transfer layer was established. At the end of that short period the wear rate dropped to about $5.5 \mu \mathrm{m} / 1000$ hours (radial wear) and stayed at that level for the next 2100 hours. At 2200 hours the drive jammed due to a tooth fracture on one of the timing gears and after rebuilding the drive the test was continued.

With the new drive the ring established, from the outset, a much higher wear rate of about $\$ 7 \mu \mathrm{m} / 1000$ hours. This higher wear rate, which continued for approximately the next 2800 hours is attributed to misallignment due to improper assembly of the drive. At 500 hours, in order to facilitate complete inspecticn. the drive was disassembled, insperted, and reassembled (this time properly'.

Upon restarting with the newly assembled drive the ring established the saine low wear rate of $5.5 \mu \mathrm{m} / 100 \mathrm{~g}$ hours which 


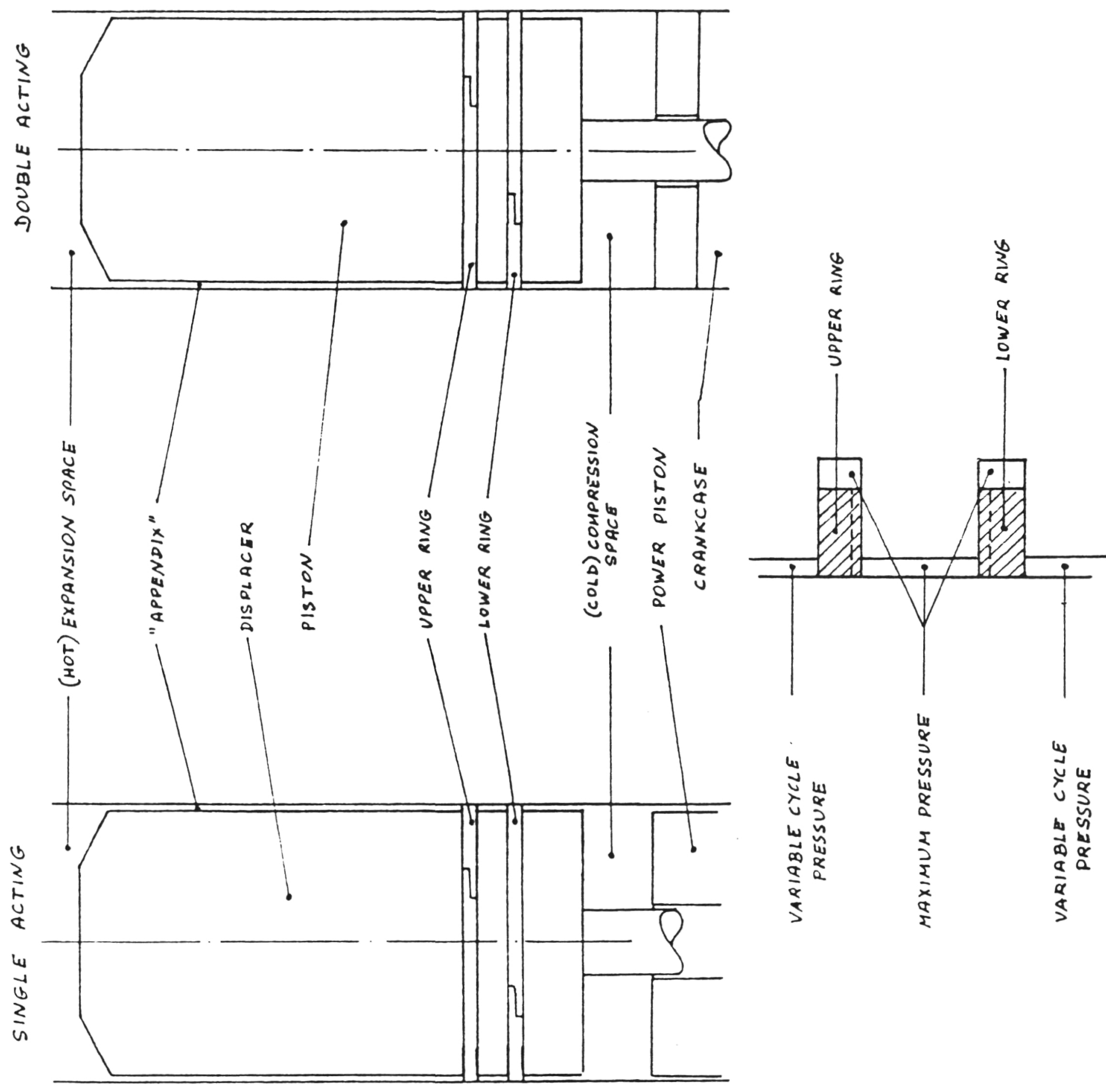




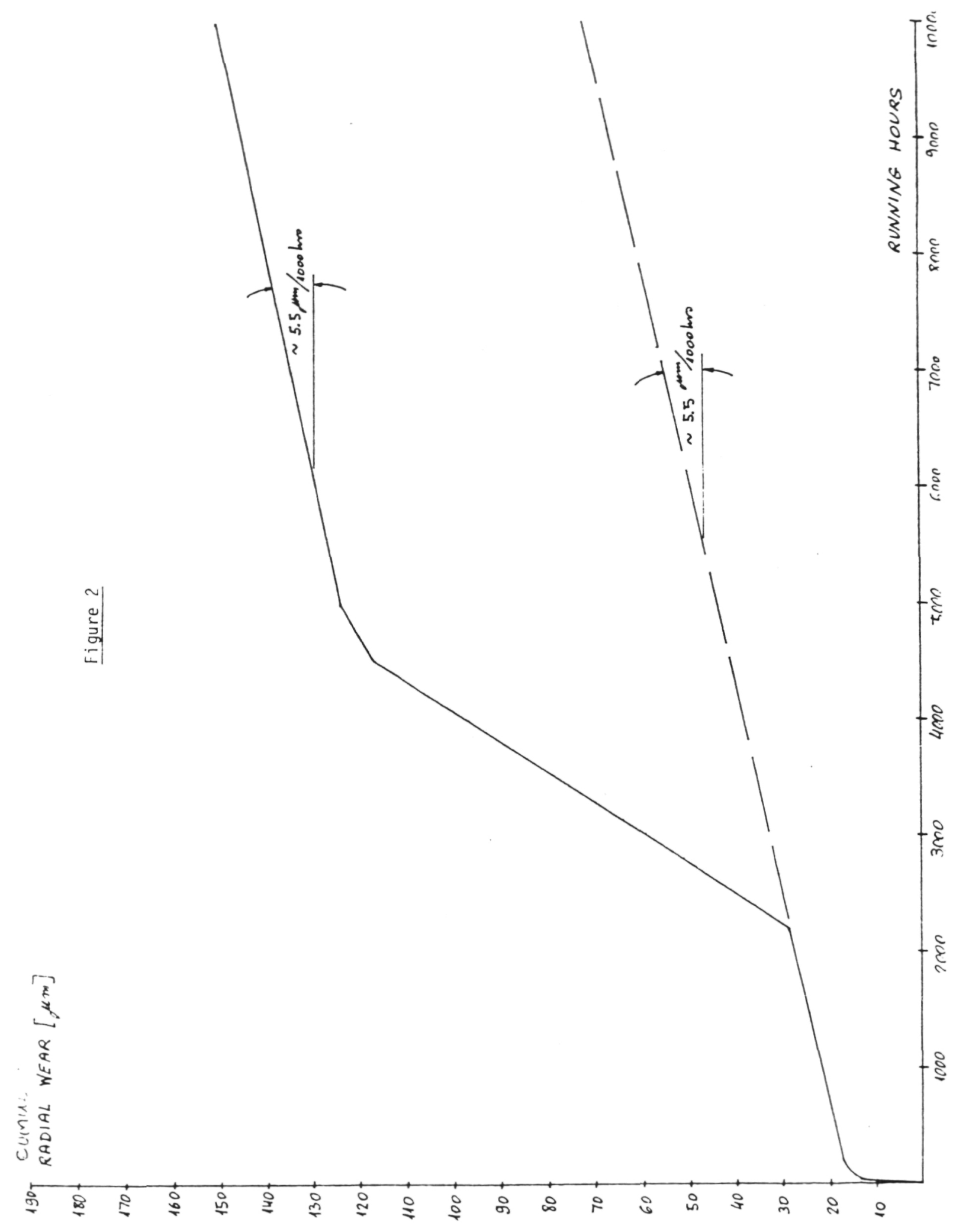


characterized its operation during the first 2100 hours. This wear rate continued for the next 5000 hours until the end of the test.

This test leads to the conclusion that barring unusually adverse circumstances (such as the improper assembly of the rhombic drive) after a short period of high wear during which the transfer layer is established the ring settles into a wear rate of about $5.5 \mu \mathrm{m} / 1000$ hours as shown by the dashed 1 ine in Figure 2 .

The conditions of the test described above are as follows:

$$
\begin{aligned}
& \text { Strole: } \$ 1.36 \mathrm{~mm} \\
& \text { Speed: } \$ 000 \mathrm{FFM} \\
& \text { Fressure: } 10.5 \mathrm{MF} a \\
& \text { Fressure ratio: } \sim 2
\end{aligned}
$$

The pv factor is:

$$
10.5 \times(1 / 5) \times .05156 \times(30 / 3000)=11 \text { (MFa) } \times(\mathrm{m} / \mathrm{sec})
$$

The pv factor of STM"s ETSE is (at full stroke):

$$
\begin{aligned}
& \text { at } 1800 \text { FFM }(25 \mathrm{~kW}): 7.4 \text { (MFa) } \times(\mathrm{m} / \mathrm{sec}) \\
& \text { at } 3000 \text { FFM }(40 \mathrm{~kW}): 12.5 \text { (MFa) } \because \text { (m/sec) }
\end{aligned}
$$

Therefore it is expected that in the ETSE operating at full stroke the usual arrangement of two lunidirectional piston rings will wear at a rate of 4 -b $/$ m/lor hours corresponding to operation between 18 M-300 FFM.

At 1800 FFM (characteristic of the solar application, =he radial wear after 50,000 hours of full load operation 15 thus 
expected to be:

$$
\begin{aligned}
& \text { Total wear after } 50000 \text { hours }=\text { initial wear of } \\
& 20 \mu \mathrm{m}+(4 \mu \mathrm{m} / 1000 \text { hours }) \because 50000 \text { hours }= \\
& 220 \mu \mathrm{m}=0.22 \mathrm{~mm}
\end{aligned}
$$

In the 1-98 the displacer rings operated properly with total radial wear of $0.15 \mathrm{~mm}$ and should continue to operate properly even with total radial wear of $0.5 \mathrm{~mm}$. Hence the usual arrangement of two unidirectional piston rings in the ETSE should exhibit life in excess of 100,000 hours.

Current developments at STM which is aimed at reducing the piston ring friction via reduction of the normal force will reduce the pv factor dramatically and thus increase the piston ring life even further. 


\section{STIRLING THERMAL MOTORS, INC.}

John W. Stearns, Jr.

Energy Technology Engineering

Jet Propulsion Laboratory

4800 0ak Grove Drive

Pasadena, CA 91109

Dear Jack:

Enclosed please find an analysis of the bearing life in our engine under various conditions of operation representing solar installations of different sizes.

Whereas the enclosed is self explanatory I would like to point out that when we discuss "life" we mean the $L_{10}$ life defined as that which $90 \%$ of the bearings will exceed.

The average life (i.e. that which half the bearings will exceed) is approximately five times longer than the $L_{10} l_{i f e}$.

It is this average life which sould be considered in projecting maintenance cost unless there are extremely severe consequences to a failure which require unusually rigorous preventive maintenance. I do not believe that this is the situation in the solar application and therefore submit that even the existing bearings will satisfy the requirements of the solar installation in the sizes considered.

I am sending a copy of the enclosure to Mr. Cairelli at NASA Lewis who has kindly agreed to ascertain that my analysis follows accepted practice.

Naturally, I will be glad to provide any additional information that you require.

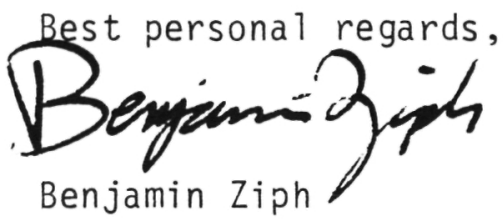

\section{$\mathrm{BZ} / \mathrm{CCW}$}

\section{Enclosure}

CC - Jim Cairelli, NASA LeRC 
The current design of the BTSE specifies rolling element bearings for the entire rotating assembly. These include two spherical roller bearings (SKF22208C) supporting the main shaft and a thrust bearing (Timken TTHD-T1750) which retains the drive shaft. The bearings are chosen so that (at full stroke) for a certain charge pressure and speed the L 10 life of all three bearings is approximately the same. This life is inversely proportional to the charge pressure to the power $c f 3.33$ and to the speed to the first power (see Appendix 1)

In the solar application of the BTSE only the speeds of 1800 rpm and 3600 rpm are compatible with the electrical requirements. Table 1 shows the bearing life for various combinations of these speeds with different charge pressures yielding shaft power (at full stroke) of $15 \mathrm{kw}, 25 \mathrm{kw}$ and $55 \mathrm{kw}$.

\begin{tabular}{lcccc}
$\begin{array}{l}\text { Charge } \\
\begin{array}{l}\text { Pressure } \\
(\mathrm{MPa})\end{array}\end{array}$ & $\begin{array}{l}\text { Speed } \\
(\mathrm{rpm})\end{array}$ & $\begin{array}{l}\text { Engine } \\
\text { Power } \\
(\mathrm{kw})\end{array}$ & $\begin{array}{l}\text { Engine } \\
\text { Efficiency } \\
(\mathrm{c})\end{array}$ & $\begin{array}{l}\text { Eearing } \\
\text { Lio Life } \\
\text { (hours) }\end{array}$ \\
\hline 6.3 & 1300 & 15 & 45 & 141,000 \\
11. & 1300 & 25 & 47 & 22,000 \\
6.0 & 3600 & 25 & 43 & 83,000 \\
13. & 3600 & 55 & 43 & 6,300
\end{tabular}

TAELE 1 Cearing Life at Different Speeds and Charge Pressures

* Design point 
Page 2

The bearing life is clearly adequate for the $15 \mathrm{kw}$ engine and also, with some sacrifice of efficiency, for the high speed $25 \mathrm{kw}$ engine.

It is, however, not adequate for the low speed $25 \mathrm{k} / \mathrm{w}$ engine and much more so for the $55 \mathrm{kw}$ engine.

This situation is easily remedied by incorporating very minor modifications to the engine, viz. using plain hydrodynamic bearings to support the main shaft and two thrust bearings, sprung back to jack to retain the drive shaft.

Appendix $\mathrm{B}$ presents performance calculations for hydrodynamic bearings for the low speed $25 \mathrm{kw}$ engine and for the $55 \mathrm{kw}$ engine and shows that such bearings as would fit in the existing space will be lightly loaded and will not increase the friction compared to spherical roller bearings. It is well known that lightly loaded plain bearings could easily withstand 100,000 hours of operation.

The thrust bearing, having to operate statically as well as dynamically, cannot be replaced with a hydrodynamic bearing. The Timken Engineering Journal asserts that when two bearings are sprung back to back the first one will carry $60 \%$ of the load and the other the remaining $40 \%$. This corresponds to an $L_{10}$ life of the heavier loaded bearing of 121,000 hours in the low speed $25 \mathrm{kw}$ engine and 35,000 hours in the $55 \mathrm{kw}$ engine. In order to accomodate two thrust bearings in the engine, the length of the end seal assembly and that of the pressure hull has to be increased by about $1-1 ! 2 "$. This is a relatively small change. 
Page 3

\section{APPENDIX A - BTSE Bearing Life Calculations}

The design specification of STM's BTSE (STM4-120) call for the following bearings:

Two SKF 22208 C spherical roller bearings simply supporting the rotating assembly; and

Timken TTHD-T1750 thrust bearing supporting the output shaft against the thrust load due to the crankcase pressure acting on the area bounded by the mechanical face seal.

The SKF catalogue (1) specifies the Basic Dynamic Capacity of the $22208 \mathrm{C}$ bearing as: $C_{10}=63600$. N and recommends using the following expression for determining the $L_{10} 1$ ife of these bearings:

$$
L_{10 \text { [nown] }]}=\frac{16667}{N[\text { rpm }]}\left(\frac{c_{10}}{p}\right)^{3.33}
$$

where $N$ is the speed and $P$ (in Newtons) is the radial load. Similarly, Timken Engineering Journal (2) specifies the dynamic capacity of the TTHD-T1750 bearing as $C_{90}=32200$. N and recommends the following expression for determining the $1 \mathrm{ife}$ :

$$
L_{10[\text { mans }]}=\frac{1,5 \times 10^{6}}{N[\mathrm{mom}]}\left(\frac{C_{90}}{P}\right)^{3.33}
$$

where $P[N]$ is the thrust load on the bearing 
Page 4

Both the radial force on the main bearings and the thrust load on the thrust bearing in the BTSE are proportional to the charge pressure of the engine as follows:

\section{$P_{\text {radial }}[N]=562 \mathrm{~mm}^{2} \times P_{m}\left[M P_{2}\right]$ \\ $P_{\text {thrust }}[\mathrm{N}]=1075_{\text {man }^{2}} \times P_{m}[\mathrm{MPa}]$}

Substitution of (3) and (4) in (1) and (2) and using the specified dynamic capacities yield:

Main bearings:

$$
\frac{1.17 \times 10^{11}}{N p_{m}^{3.33}}
$$

Thrust bearing:

$$
\frac{1.24 \times 10^{11}}{N p_{m}^{3.33}}
$$

where $L_{10}$ is in hours, $N$ in $r p m$ and $P_{m}$ in $\mathrm{MPa}$.

Since (5) and (6) are within $6 \%$ of each other (5). can be taken to generally represent the 1 ife of all bearings in the engine. Thus the bearing life in the engine is inversely proportional to the engine speed raised to the first power and the charge pressure raised to the power of 3.33 . 
Page 5

APPENDIX B

Performance of Plane Hydrodynamic Bearings in the BTSE (STM4-120)

1) Low speed (1800 rpm) $25 \mathrm{kw}$ engine (charge pressure: $11 \mathrm{MPa}$ )

Radial load

Journal radius

Bearing length

Speed

$0 i 1$ viscosity

Radial Clearance
$N=6810 \mathrm{~N}$

$r=20 \mathrm{~mm}$

$l=25 \mathrm{~mm}$

$\gamma=30 \mathrm{rev} / \mathrm{sec}$.

$\mu=.0138 \mathrm{~kg} / \mathrm{msec}$

$E=10 \mathrm{~mm}$

Unit load

$$
p=\frac{N}{2 r l}=\frac{6810}{2 \times 0.02 \times 0.025}=6.81 \mathrm{MPa}
$$

reduced radius

$$
\frac{r}{c}=\frac{20}{10 \times 10^{-3}}=2000
$$

$$
S=\left(\frac{r}{c}\right)^{2} \frac{\mu \nu}{p}=2000^{2} \frac{.0138 \times 30}{6.81 \times 10^{6}}=0.244
$$

From Fig. Bl:

$$
\frac{r}{c} f=5.4
$$

Friction coefficient: $\quad f=\frac{5.4}{2000}=2.7 \times 10^{-3}$

The friction coefficient of a spherical roller bearing is approximately $2.5 \times 10^{-3}$ so the plain bearing does not increase friction loss. 
Page 6

Figure $\mathrm{B} 2$ shows that the bearing falls well within the realm of lightly loaded bearings and that the reduced minimum film thickness is:

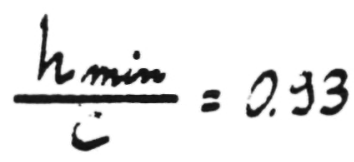

hence:

the minimum film thickness:

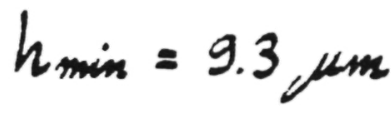

The unit load of $6.81 \mathrm{MPa}$ is relatively low: it is well below the maximum recommended value of $8.3 \mathrm{MPa}$ for Cadmium base bearings and far below the maximum recommended value of $13.8 \mathrm{MPa}$ for Copper Lead bearings (3).

2) $55 \mathrm{kw}$ engine (3600 rpm, $13 \mathrm{MPa})$

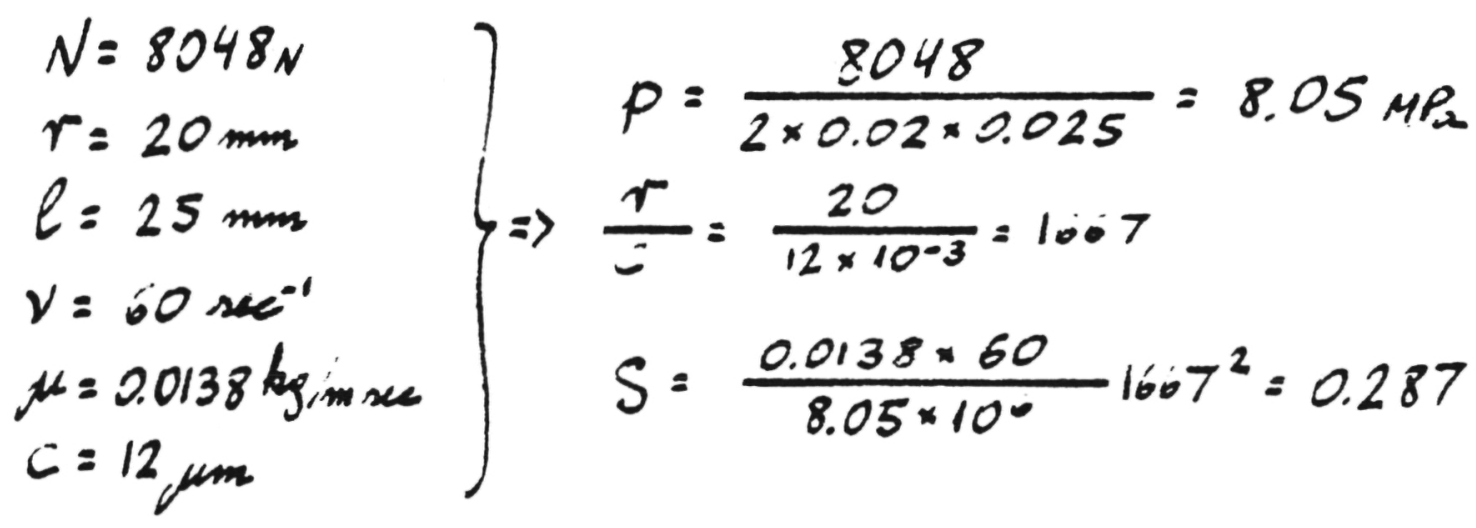

(Symbols identified in calculation for $25 \mathrm{~kW}$ engine above)

From Fig. Bl: $\frac{r}{c} f=6.2 \Rightarrow f=\frac{6.2}{1667}=3.72 \times 10^{-3}$

The friction coefficient is somewhat higher than that $\left(2.5 \times 10^{-3}\right)$ of spherical roller bearings by the amount $\Delta f=(3.72-2.5) \times 10^{-3}=1.22 \times 10^{-3}$. This will contribute the following increase $\left(\Delta P_{\boldsymbol{f}}\right)$ in power loss due to both main bearing friction: 
Page 7

$\Delta P_{f}=4 \pi N \Delta f y r=4 \pi \times 8048 \times 1.22 \times 10^{-3} \times 60 \times 0.02=148$ wott

This will reduce the efficiency by the amount $4 \mathcal{Z}$ as follows:

$$
\Delta z=\xi_{\text {sh }} \frac{\Delta P_{i}}{P_{\text {sh }}}=43 \times \frac{0.148}{55}=0.116 \% \text { points }
$$

This decrease in efficiency is rather negligible.

From Fig. $2 B$ it is evident that the bearings are lightly loaded and the minimum film thickness is:

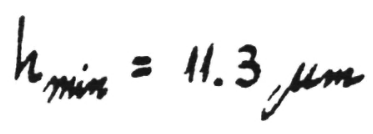

The unit load is still below the maximum recommended for Cadmium base bearings ( $8.3 \mathrm{MPa}$ ) and well below that for Copper Lead bearings (13.8 MPa). 


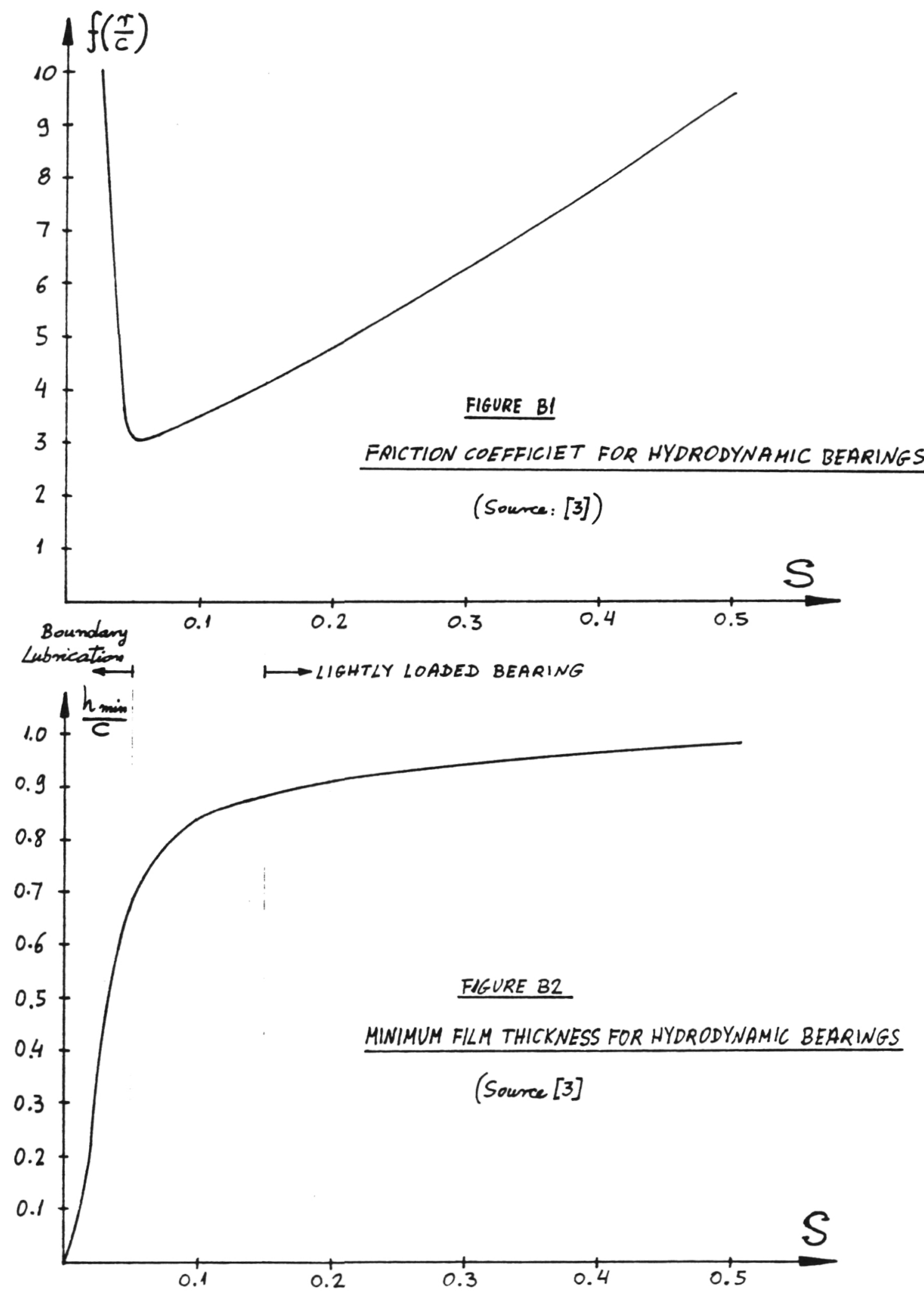




\section{REFERENCES}

1) Timken Engineering Journal, The Timken Company, Section 1, General Information, 1972 .

2) Detroit Ball Bearing Catalog, $ّ 79$, 1978, Sec. 3, pgs. 69, 161, Detroit Ball Bearing Company, Detroit, Michigan.

3) Analysis and Lubrication of Bearings, Milton C. Shaw and Fred Macks, McGraw-Hil1 Book Company, Inc., 1949. 


\section{APPENDIX C}

UTILITY POWER PURCHASE, INCLUDING

COMBUSTOR AND THERMAL STORAGE

C-1 


\section{APPENDIX C}

Utility Power Purchase, Including Combustor and Thermal Energy Storage

Energy storage has been identified by several utilities as a feature contributing to the increased value of solar electric generation (Ref. C-1). Low-cost energy storage may be provided by fossil fuels (especially natural gas) and by latent heat thermal storage at the focal point of the dish-Stirling module. Bonus capacity payment will also be provided if energy delivery can be made independent of cloud cover and other unscheduled outage conditions. Solar-only generation is basically unscheduled power for which only minimum capacity rating can be assigned.

The introduction of the fossil fuel combustor with thermal energy storage improves the capacity rating of the system. Additionally, thermal storage is able to provide the highest efficiency for active energy storage (approximately 90 percent). The combustor assures that the energy storage is maintained irrespective of cloud cover or nighttime operating needs. The technologies for thermal storage and the hybrid combustor have been demonstrated (Ref. C-2). Very-low-cost approaches have recently become available (Ref. C-3).

Power Purchase Agreements available from Southern California Edison Company are given in Appendix D. In the southwestern U.S., cloud cover may be expected approximately $10 \%$ of the time during the six months of the "summer" rate schedule and approximately 20 percent of the time during the remaining "winter" rate schedule. On-peak, mid-peak, and off-peak hours are defined in Appendix D. Direct insolation (solar flux) for the southwest U.S. is shown in Figure C-1, for summer solstice and winter solstice conditions. Peak-toaverage power is approximately 1.22 . 
For analysis purposes hereunder, a $25 \mathrm{kWe}$ dish-Stirling module was assumed. This is consistent with present technology being demonstrated, with a dish size of 10-11 meters diameter. However, the "Innovative Concentrator" work in progress for future demonstration will have a diameter of 14-15 meters and a power level of $50-60 \mathrm{kWe}$.

Table C-1 is a scenario for solar-only operation. Credit is given for on-peak, mid-peak, and off-peak operation, for the insolation defined in Figure $\mathrm{C}-1$, accounting for cloud cover, and according to the rate schedules of Appendix D. The annual value of solar-only operation is approximately $\$ 4068$ at a total energy output of $61582 \mathrm{kWhe}$. This is an average $6.6 \phi / \mathrm{kWhe}$. The equipment is operated for approximately 3681 hours per year. The specific value of this system, at a capacity factor of 0.28 , is $\$ 163 / \mathrm{kWe}$-year (peak). Hybrid operation is accomplished by adding a fossil fuel combustor to the dish-Stirling module. The value is increased as shown in Table C-2. The combustor fills in during days of cloud cover, and thus provides a guaranteed power output each day. An 18 percent capacity bonus is given by the utility for such guarantees. However, off-peak hours on weekends and holidays are not given any capacity credit and are therefore just operated solar-only. Total annual energy output of the hybrid system is increased to $70,720 \mathrm{kWhe}$, increasing the capacity factor to 0.32 . Total annual value to the utility increases to $\$ 4967$. Fuel cost, however, at $\$ 4.62 / 106 \mathrm{Btu}$, is $\$ 380$ for the year, assuming a heat rate of approximately $9000 \mathrm{Btu} / \mathrm{kWhe}$ ( 85 percent combustor efficiency). Thus, net energy value is $\$ 4587$ or $\$ 183 / \mathrm{kWe}$-year (peak). This is a 13 percent increase of the hybrid system over the solar-only system, while capacity rating has been increased by 14 percent. 
The further addition of thermal energy storage (TES) will also add to system value. However, it does so primarily by allowing changes to the components of the dish-Stirling system to reduce cost. For a 25-kWe system, concentrator size can be reduced, or, if concentrator size is maintained constant, the output power is increased. Since it is economically important to maintain concentrator size at a constant optimum, the scenario chosen in Table C-3 is to increase the PCU output power level. A peak power output of $27 \mathrm{kWe}$ will be needed in the present example. Approximately two full power hours ( $50 \mathrm{kWhe}$ ) of TES are assumed to enhance and augment solar operation. In addition, 10 percent losses are supplied by solar operation during off-peak hours and by combustor during cloud cover conditions.

For the TES operation, capacity factor is not increased significantly. However, by shifting operation from off-peak to on-peak hours, value for the system is increased over the solar-only case by 27 percent (hybrid + TES operation), compared to 13 percent for just the hybrid operation.

A fourth scenario should also be considered for the SCE value profile, in which a combustor and Stirling engine operate (without solar) in a combustoronly mode. If operated only at on-peak hours, a value of $\$ 0.14468 / \mathrm{kWhe}$ is recognized for the summer peak $(762 \mathrm{~h})$ and $\$ 0.06989 / \mathrm{kWhe}$ for the winter peak $(625 \mathrm{~h})$. Annual value for a $25-\mathrm{kWe}$ system is $\$ 3848.18-1442.48$ (fuel) $=$ $\$ 2405.70$ net. Added operation for mid-peak hours almost triples the number of operating hours and adds a net value of $\$ 572.78$. Depending on O\&M requirements, there may be some value in operating over the longer period. But extra O\&M costs must be well within $\$ 20 / \mathrm{kWe}$-year. 
Figure C-1

(

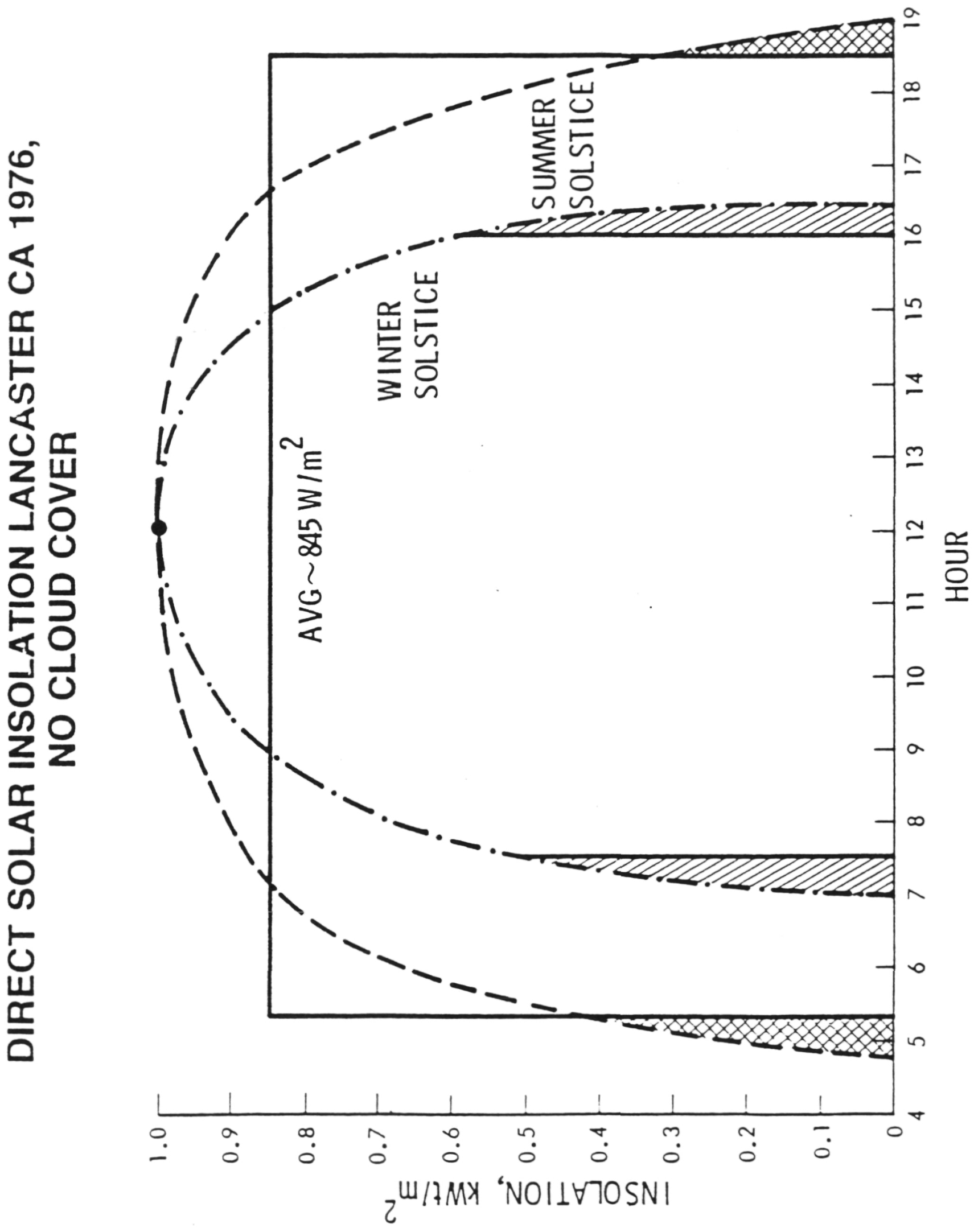


Table C-1

SCE/Dish-Stirling Solar Only Scenario

Summer $182 \mathrm{~d}, 4368 \mathrm{~h}$

(PDT)

Winter 183d, 4392h

(PST)

\begin{tabular}{llllllll}
\hline & \multicolumn{3}{c}{$(\phi / k W h e)$} & & \multicolumn{2}{c}{$(\phi / k W h e)$} \\
Credit & & Fuel & Cap. & & \multicolumn{2}{c}{ Fuel } & Cap. \\
& & & & & & \\
On-peak & $1 p-7 p(762 h)(127 d)$ & 5.2 & 7.854 & $5 p-10 p(625 h)(125 d)$ & 5.2 & 1.516 \\
Mid-peak & $9-1,7-11(1016 h)(127 d)$ & 4.9 & 0.120 & $8 a-5 p(1125 h)(125 d)$ & 4.9 & 0.424 \\
Off-peak & Other $(2590 h)(182 d)$ & 4.7 & 0.0 & Other $(2642 h)(183 d)$ & 4.7 & 0.022 \\
\hline
\end{tabular}

Summer Solstice: 6 AM - 8 PM operation.

Winter Solstice: 7 AM - 5 PM operation.

$\underline{\text { Summer }}$

On-peak: $1 \mathrm{p}-7 \mathrm{p}(762 \mathrm{~h}-10 \%$ Cloud Cover $=686 \mathrm{~h})$ e $18.12 \mathrm{kWe}$ avg $12430 \mathrm{kWh}$ e $13.054 \mathrm{k} / \mathrm{kWh}=\$ 1622.61$

Mid-peak: $9 a-1 p(508-10 \%=457 \mathrm{~h})$ e $21.2 \mathrm{kWe}$ avg

$9688 \mathrm{kWh}$ e $5.020 \phi / \mathrm{kWh}=\$ 486.34$

Off-peak: $7 a-9 a(127 d * 2.0 \mathrm{~h}-10 \%=229 \mathrm{~h})$ e $15.4 \mathrm{kWe}=3527 \mathrm{kWh}$

$7 \mathrm{a}-7 \mathrm{p}(50 \mathrm{~d} * 12 \mathrm{~h}-10 \%=540 \mathrm{~h})$ e $18.1 \mathrm{kWe}=9774 \mathrm{kWh}$

$13301 \mathrm{kWh}$ e $4.7 \phi / \mathrm{kWh}=\$ 625.15$

Subtotal: $1912 \mathrm{~h} ; 35419 \mathrm{kWh} ; \$ 2734.10 ; \$ 0.0772 / \mathrm{kWh} ; \$ 109.36 / \mathrm{kWe}$-year

Winter

On-peak: 0

Mid-peak: $8 a-5 p(1125 \mathrm{~h}-20 \%=900 \mathrm{~h})$ e $18.22 \mathrm{kWe}$ avg

$16398 \mathrm{kWh}$ e $5.3244 / \mathrm{kWh}=\$ 873.03$

Off-peak: $7 \mathrm{a}-8 \mathrm{a}(125 \mathrm{~d} * 1 \mathrm{~h}-20 \%=100 \mathrm{~h})$ e $13.2 \mathrm{kWe}=1320 \mathrm{kWh}$

$7 a-5 p(58 d * 10 h-20 \%=464 h)$ e $18.2 \mathrm{kWe}=8445 \mathrm{kWh}$

$9765 \mathrm{kWh}$ @ $4.722 \phi / \mathrm{kWh}=\$ 461.10$

Subtotal: 1464h; $26163 \mathrm{kWh} ; \$ 1334.13 ; \$ 0.0510 / \mathrm{kWh} ; \$ 53.37 / \mathrm{kWe}-$ year

Totals: $3376 \mathrm{~h} ; 61582 \mathrm{kWh} ; \$ 4068.23$; $\$ 0.0661 / \mathrm{kWh} ; \$ 162.73 / \mathrm{kWe}-$ year (peak)

Capacity factor: 0.28 


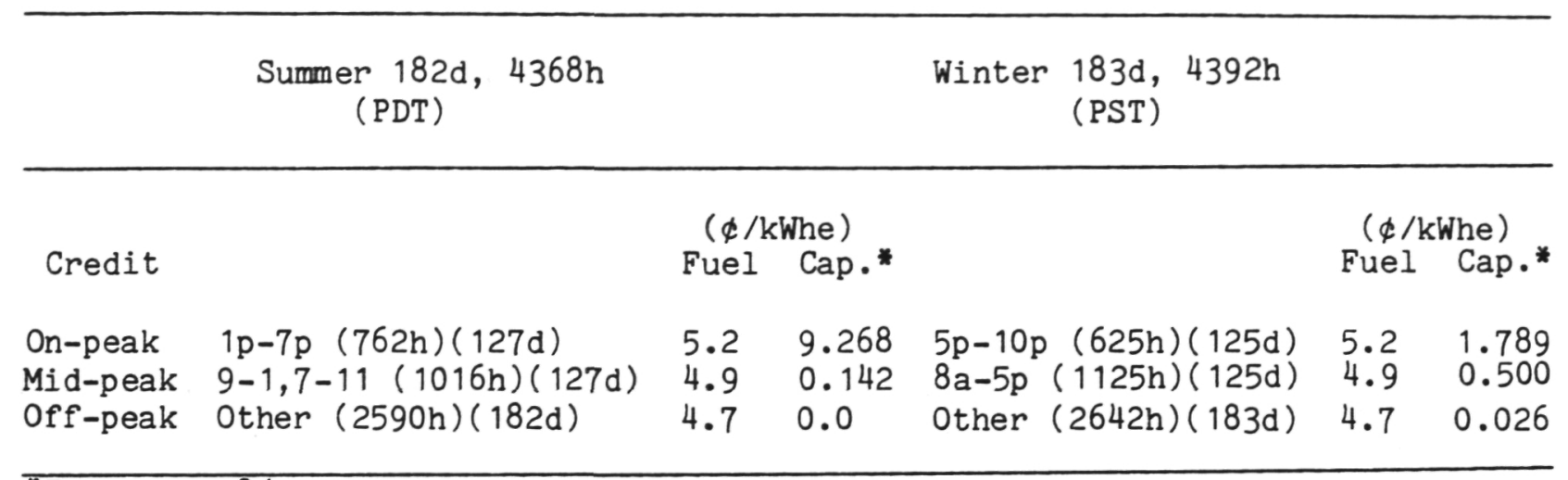

*Includes 18\% Bonus

Summer Solstice: 6 AM - 8 PM operation.

Winter Solstice: 7 AM - 5 PM operation.

Summer

On-peak: Combustor 10\% $=76 \mathrm{~h}$ e $25 \mathrm{kWe}=1900 \mathrm{kWh}+$ Solar $12430 \mathrm{kWh}$

$14330 \mathrm{kWh}$ e $14.468 \phi / \mathrm{kWh}=\$ 2073.26$

Mid-peak: Combustor $10 \%=51 \mathrm{~h}$ e $25 \mathrm{kWe}=1275 \mathrm{kWh}+$ Solar $9688 \mathrm{kWh}$

$10963 \mathrm{kWh}$ e $5.042 \phi / \mathrm{kWh}=\$ 594.19$

Off-peak: No Combustor; Solar $=13301 \mathrm{kWh}$

$13301 \mathrm{kWh}$ e $4.7 \varnothing / \mathrm{kWh}=\$ 625.15$

Subtotal: 2039h; $38594 \mathrm{kWh;} \$ 3292.60 ; \$ 0.0853 / \mathrm{kWh} ; \$ 131.70 / \mathrm{kWe-year}$ (peak)

Winter

On-peak: Combustor $20 \%=13.5 \mathrm{~h}$ e $25 \mathrm{kWe}=337.5 \mathrm{kWh}$

$337.5 \mathrm{kWh}$ e $6.989 \phi / \mathrm{kWh}=\$ 23.59$

Mid-peak: Combustor $20 \%=225 \mathrm{~h}$ e $25 \mathrm{kWe}=5625 \mathrm{kWh}+$ Solar $16398 \mathrm{kWh}$ $22023 \mathrm{kWh}$ e $5.40 \phi / \mathrm{kWh}=\$ 1189.24$

Off-peak: No Combustor; Solar $=9765 \mathrm{kWh}$

$9765 \mathrm{kWh}$ e $4.726 \phi / \mathrm{kWh}=\$ 461.49$

Subtotal: 1702.5h; $32125.5 \mathrm{kWh} ; \$ 1674.32 ; \$ 0.0521 / \mathrm{kWh} ; \$ 66.97 / \mathrm{kWe}-\mathrm{year}$ (peak)

Totals: $\quad 3741.5 \mathrm{~h} ; 70719.5 \mathrm{kWh} ; \quad \$ 4966.92 ; \$ 0.0702 / \mathrm{kWh} ; \$ 198.68 / \mathrm{kWe}-y e a r$ (peak) Combustor: $365.5 \mathrm{~h} ; 9137.5 \mathrm{kWh} ;-\mathbf{- \$ 3 7 9 . 9 4}$

Net :

$\$ 4586.98 ; \$ 0.0649 / \mathrm{kWh} ; \$ 183.48 / \mathrm{kWe}$-year (peak)

Capacity factor: 0.32 


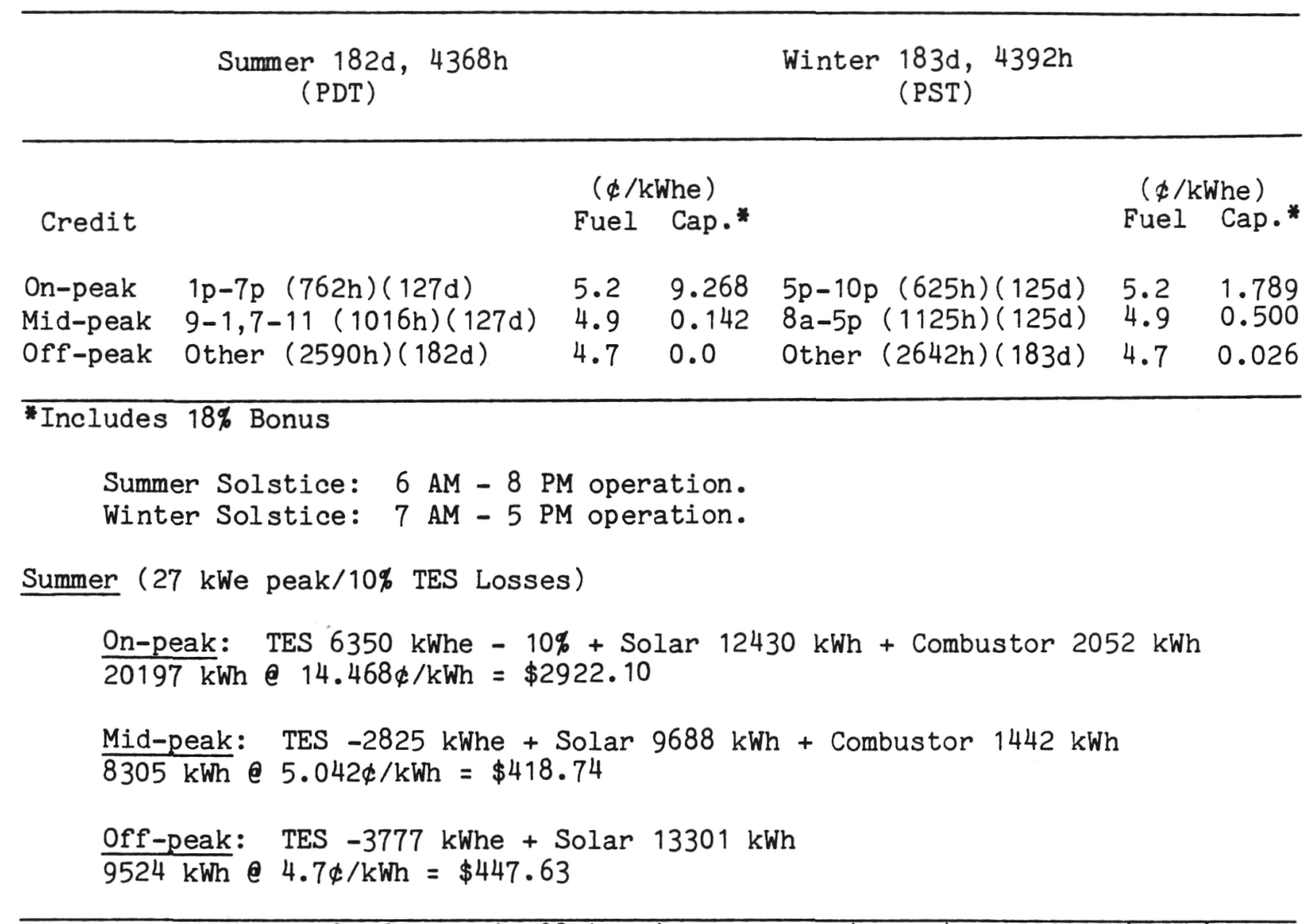

Subtotal: 2041h; $38026 \mathrm{kWh} ; \$ 3788.47 ; \$ 0.010 / \mathrm{kWh} ; \$ 151.54 / \mathrm{kWe}$-year (peak)

\section{Winter ( $27 \mathrm{kWe}$ peak/10\% TES Losses)}

On-peak: TES $6250 \mathrm{kWhe}-20 \%$ + Combustor $1350 \mathrm{kWh}$

$6350 \mathrm{kWh}$ e $6.989 \phi / \mathrm{kWh}=\$ 443.80$

Mid-peak: TES -4075 kWhe + Solar $16398 \mathrm{kWh}+$ Combustor $6200 \mathrm{kWh}$ $18523 \mathrm{kWh}$ e $5.40 \phi / \mathrm{kWh}=\$ 1000.24$

Off-peak: TES -1550 kWhe + Solar $9765 \mathrm{kWh}$

$8215 \mathrm{kWh}$ e $4.726 \notin / \mathrm{kWh}=\$ 388.24$

Subtotal: 1744h; $33088 \mathrm{kWh} ; \$ 1832.28 ; \$ 0.055 / \mathrm{kWh} ; \$ 73.29 / \mathrm{kWe}-$ year

Totals: $3785 \mathrm{~h} ; 71114 \mathrm{kWh}$; $\$ 5620.75 ; \$ 0.079 / \mathrm{kWh} ; \quad \$ 224.83 / \mathrm{kWe}-$ year

Combustor: $408 \mathrm{~h} ; 11044 \mathrm{kWh} ;-\$ 459.43 \quad-\$ 8.38$

Net:

Capacity factor: 0.325 


\section{References}

C-1 "Southwest Project, Resource/Institutional Requirements Analysis," Volume 1, Executive Summary, Stone \& Webster Engineering Corporation, Contract No. EM-77-C-01-8720, Report No. DOE/CS/8720-1, December 1979.

C-2 "Heat Pipe Solar Receiver, Detailed Design Review," General Electric Company, Advanced Energy Programs Department, Contract No. 955400 (JPL), October 1980.

C-3 Chen, K., and Manvi, R., "Metal-Halide Mixtures for Latent Heat Energy Storage," Solar Engineering-1981; Proceedings of the Third Annual Conference on System Simulation, ASME, pp. 667-674, Reno, NV, 1981. 
APPENDIX D

SOUTHERN CALIFORNIA EDISON CO. AVOIDED COST PRICING AND POWER PURCHASE (1984) 


\section{APPENDIX D}

\section{Southern California Edison Company}

Avoided Cost Pricing and Power Purchase

On-peak, mid-peak, and off-peak power are defined in Table 1. Based on these definitions, avoided cost pricing is shown in Table 2 (four pages) for cogeneration and small power producers. The avoided energy-cost payment schedule is shown on page 2 , to which is added the capacity payment schedule of page 4. Capacity payments are increased for multiyear contracts, as shown in the payment schedule for "Standard offer No. 2."

A typical long-term Power Purchase Contract form is included, by reference, in this Appendix. Only the cover page and Table of Contents of this document (No. 1505C) are included here as Table 3 (three pages). Copies may be obtained from SCE directly. 


$$
\begin{array}{lc}
\text { ON-PEAK } & 762 \\
\text { MID-PEAK } & 1016 \\
\text { OFF-PEAK } & 2590 \\
\text { TOTAL SUMMER } & 4368
\end{array}
$$

$$
\begin{aligned}
& \text { DN-PEAK } \\
& \text { MID-PEAK } \\
& \text { DFF-PEAK }
\end{aligned}
$$$$
\text { TOTAL WINTER }
$$

$$
\frac{\text { LEAPYEAR }}{630}
$$$$
1134
$$$$
2652
$$$$
\frac{\text { NORMAL }}{625}
$$$$
1125
$$$$
2642
$$

TOTAL 1989 TOU-8 HOURS

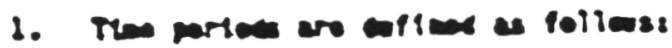

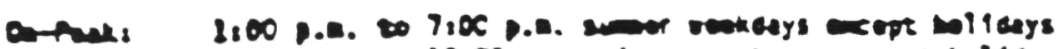

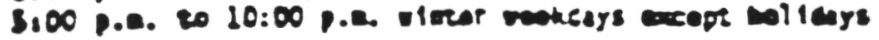

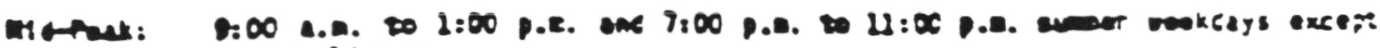
nol laeys

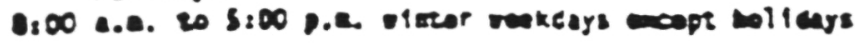

CPAnes Als cher nours.

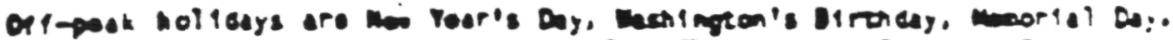

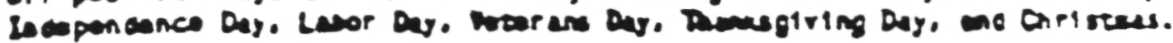

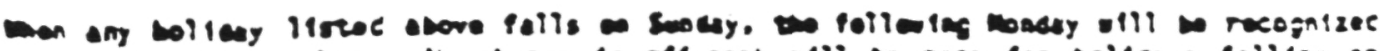

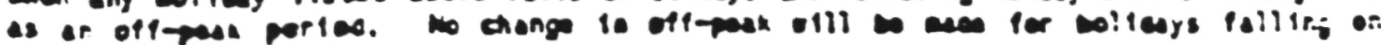
Saturay.

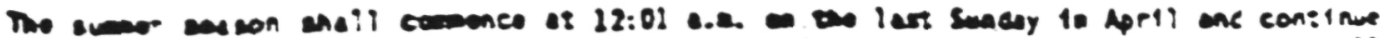

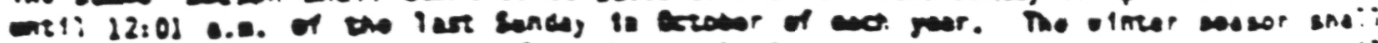

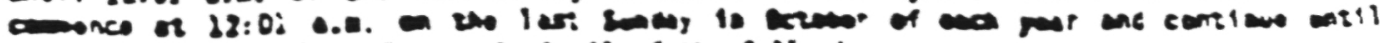

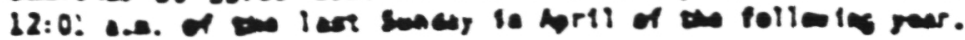


P O BOX 000

2244 WALNUT GROVE AVENUE

ROSEMEAD. CALIFORNIA 91770

AVOIDED COST PRICIMG OPDATE

FOR COGENERATION AMD SMLLL PONER PRODOCERS

May 1984

Enclosed are the prlce schedules In effect May 1, 1984, through July 31. 1984, for electrlcal capacity and energy purchases frow Qualifylng

Faclilties (QFs) located in Edlson's service area and pursuant to Standard offer contracts.

\section{ENERGT}

In accordance with requirements, Edison flled with the Callfornia Public Ut111:1es Commission on Apr11 2, 1984, the prospective energy prices for the May 1, 1984-Juiy 31, 1984, perlod. The following energy prices. reilect the continued use of natural gas as Edison's Incremental Puel at the Indexed Southern Callfornla Gas Company GN-5 rate of $\$ 4.62$ per al1110n Biu in effect on May 1, 1984. Edison has been directed by the CPUC to retroactively adjust energy payments each wonth to reflect the blgher GN-5 rate of $\$ 5.67$ per mililon Btu for gas purchases on Eplsode days experienced withln the South Coast Air Quality Managezent District for the period of May 1 through July 31, 1984.

\begin{tabular}{lc} 
May 1 - July $31, \frac{1984}{6 / k j h}$ \\
\hline \\
On-Peak & $5.2-$ \\
MId-Peak & 4.9 \\
Off-Peak & 4.7 \\
Ilde Perlod & 4.9 \\
Welghted lverage
\end{tabular}

\section{CAPACITI}

The capacity payment schedule for Standard Orfers Nos. 1, \& 3 has been updated effective January 1, 1984 to reflect 1984 shortage costs and is enclosed for your information and use.

The capacity payment schedule for Standard Opfer No. 2 became effective Eebruary 14, 1983 and applies prospectlvely for new contracts. Capacity payments for projects beginnling dellvery in 1988 have been added to the schedule.

\section{GENERAL}

CPUC Decision No. 82-12-120 applied to certain standard offer pricing provisions. The Commission lssued subsequent decisions on October 19. 1983, and March 21, 1984, coverlag several lssues ralsed during past compliance hearings which further modify Edison's standard offers. Modiflcations in accordance with the October 19, 1983, declsion were Plied on December 2, 1983. Further modiflcatlons in accordance with the March 21. 1984, decision will be Plled with the Comalssion on May 4, 1984 . OFs who I I n standard contracts between December 30, 1982, the effective date of Decision No. 82-12-120, and May 4, 1984, the Pliling date for modlelcations in compllance with the Commission's March 21, 1984, decision will be given the opportunlty to switch from the Interla contract to the Standard offer contract then in efrect. QFs may not switch from one standard offer to another, but ay adopt the current version of the partlcular offer signed. QF wili have thirty (30) days Prom May 4, 1984, In whlch to sign the current version of the Standard offer.

If you require assistance in using the enclosed capaclty or energy payment schedules or would like to recelve coples of our standard Agreements.

please direct your Inquirles to Southern Callfornia Edison Company.

Cogeneration and Small Power Development, P.0. Box 800, Rosemead,

Calleornia 91770 , or telephone (818) 572-1419. 


\title{
ORIGINAL PAGE IS \\ Page 2 of 4 \\ OF POOR QUALTTY
}

\section{SOUTEERM CALIFORMIA EDISON CORTANY}

Arolded Enerey-Cost Payment Schedule a Calculation

Effect!re May 1, 1984 - July 31, 1984

\section{PAYMENT SCHEDULE}

AVOIDED ENERGY PRICE $\left(\xi / K H_{H}\right)^{-}$ Time-He1Ghted Average $\left(\xi / K H_{H}\right)^{\circ}$
ON-PEAK MID-PEAK OFF-PEAK

$\begin{array}{lll}5.2 & 4.9 & 4.7\end{array}$

- values reflect summer period heat rates, and exclude adjustments fod LINE-LOSSES.

\section{CALCULATIOH}

\begin{tabular}{|c|c|c|c|}
\hline & $\underline{\text { On-Peak }}$ & Mid-Peak & orf-peak \\
\hline $\begin{array}{l}I 1 \\
I 2\end{array}$ & 1.0 & 1.0 & 1.0 \\
\hline $\begin{array}{c}\text { Gas Price ( } \$ / M 111 \text { ion Btu) } \\
\text { Indexed GN-5 Rate }\end{array}$ & 4.62 & 4.62 & 4.62 \\
\hline $0 ! 1$ Price (\$/M!1110n Btu) & N/A & N/A. & N/A \\
\hline $\begin{array}{l}\text { Heat Rates }(B: u / k W h) \\
\text { Su=zer } \\
\text { Wiater }\end{array}$ & $\begin{array}{r}10,490 \\
9,580\end{array}$ & $\begin{array}{l}9,920 \\
9,650\end{array}$ & $\begin{array}{l}9.380 \\
9.350\end{array}$ \\
\hline $\begin{array}{l}\text { Hea: Ra:e Conversion Factors } \\
\text { Gas Euel } \\
0: 1 \text { Euel }\end{array}$ & $\begin{array}{l}1.035 \\
1.000\end{array}$ & $\begin{array}{l}1.035 \\
1.000\end{array}$ & $\begin{array}{l}1.035 \\
1.000\end{array}$ \\
\hline $\begin{array}{c}\text { Dine-ioss 5acsors } \\
\text { transagsion } \\
\text { p::=ary }\end{array}$ & $\begin{array}{l}1.025 \\
1.032\end{array}$ & $\begin{array}{l}1.025 \\
1.032\end{array}$ & $\begin{array}{l}1.025 \\
1.032\end{array}$ \\
\hline Va: $a=l e ~ 0 s y(=/ k j t)$ & 0.2 & 0.2 & 0.2 \\
\hline
\end{tabular}

Avoited Energy-Cost Calcula:Lon:

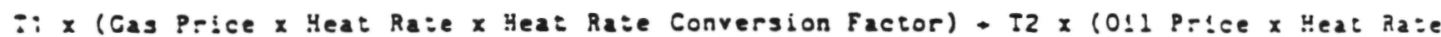

a ت̈ear Raze Convergion Factorl - Varbable ObM $x$ Line-Loss Factor

dhere, for each on-peak, wid-peak, of:-peak and seasonal pertod:

II a Proportion of tiae gas use ls expected to be avolded

72 = proportion of tiae oll use ls expected to be avoided

\begin{abstract}
Cas P-ice is Southern Cal1forala Gas Company's lndexed GN-5 Rate por P-5 custogers 10 efrect at ilje energy prices take ef:ect. Edison has been directed by ine C?uC io retroactively adjust the avolded cost energy prices each anth io re?lect the use of natural gas at the $n 1$ aner GN-5 rate of $\$ 5.67$ per al1110n Btu durlag Eplsode days experienced during the posting perlod.

011 Price ls price of oll into Inventory based on aso recent quarterly purchases.

Heat Rate is average-year (hydro, etc.) Incremental heat rate, as deternined in aost recen:

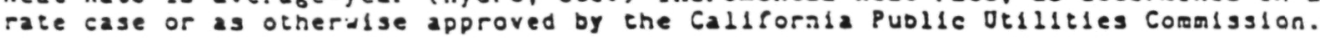

Heat Race Conversion Factor adjus:s the adopted Incremental oll Heat Rates for gag-puel e::letency loss when gas ls the avolded ruel.

Var!abie OdM is Incremenial operations and aalntenance cost.

Line-Losg Factor 19 an adjugtment to reflect any agregate line losses avolded. Curren: :y, set at 1.025 and 1.032 for Trangmisgion and Primary Distribution voltage levels, respec:tvely, per C?'JC Dec1s!on No. 8t-03-092.
\end{abstract}


ATOIDED COST CAPACITI PAICIMG

POR COCENERATION AND SMLLL POVER PRODOCERS

May 1984

On Decenber 2, 1983, and In compllance with Comission Decision

No. 83-10-093. Edlson siled and ade effectlve amendaents to lis three

standard Contracts for power purchases froa qualifylag facilleles (OFs) and thelr asoclated capaclity payaent schedules. These agreeaents and capactiy payment schedules are applicable to OFs located in Edison's service area, and are sumarlized below:

1. As-dvallable Power Purchase (Standard Offer Mo. 1). Comalts ouner of - QE to provlde Edlson with electrical energy and capaclty on an asavallable basis.

- Capacley Payments - See enclosed schedule for As-Avallable Pover Purchases.

2. Flra Power Purchase (Standard Orfer No. 2). Comilts owner to operate Its QF Por a specifled tera and to dedlcate all or a portlon of the output of the QF to EdIson. The owner may lect to serve all or part of the on-slte load from the QF, with the balance of that load served by Edison under existing tariffs if required.

Tey provislons of Standard Offer Mo. 2 are as follows:

The capacity payment provlsions Include two payment optlons:

(1) based on aE's avallablllty/d1spatchablllty perforsance: and

(2) based on aE's energy production or output (capacity lactorl delivered to Edison.

- Minlaum performance requirements bave been established for each payment option. A QF falling to eeet these requirements will be subject to teaporarily reduced capaclty payments and possible peraanent reducilon In contract capacity in conjunction wi:h lialted reimbursement and replacement payments to Edison.

- A QF can recefre bonus capacity payaenes of up to 18: above Ed!son's avoided capac: :y cost if per:ormance consistently exceeds specifled thresnold levels and considering allowances for porced and scheduled outazes.

- The teralnation provislons of Standard Offer No. 2 require a $Q f$ terainating all or a portion of the capaclity comeituent with prescribed notlce to relmburse Edison for unearned capacisy payments with laterest. A QF terainating without prescribed notice is also required to make a one-time capacity replacement payment for the terminated capacity.

Capacity Payments - See enclosed schedule for Fira Power Purchases. OFs aantalning an 808 level of performance will be - ligible to eara tae full schedule payaent. The capacity payment schedule is eifective prospectively for new contraces and does not apply to existing contracts.

3. Cogeneration or Seall Power Production Geaeration Agreement for Quall:ying Facillties Under $100 \mathrm{~kW}$ (Standard Offer No. 3). Commits owner of a OE for a one-year ainluum tera to elther supply all or a part of the on-site load from the QF or to sell the total electrical output to Edison.

- Capaclty Payments - See enclosed schedule For As-Avallable Power Purchases.

The enclosed capaclty payment schedules wlll be updated at least blennlally in connection with Commission proceedings involving Edison general rate cases.

SOUTHERN CALIPORMIA EDISON COMPAMY 


\section{ORIGINAL PAGE IS \\ OF POOR QUALITY}

SOUTBERM CALIFORMIA EDISON COMPAMY

CAPACITY PAYMENT SCHEDOLE TOR STANDARD OFTER NO. MUS-ATAILABLE POWER PORCBUSE

EFPECTIVE JANOARY 1, 1984

\begin{tabular}{|c|c|c|c|}
\hline & & : & 2 \\
\hline $\begin{array}{l}\text { : Line } \\
\text { : No. }\end{array}$ & Costing Perlod & $:$ & Capacity Paywent \\
\hline
\end{tabular}

(I)

(2)

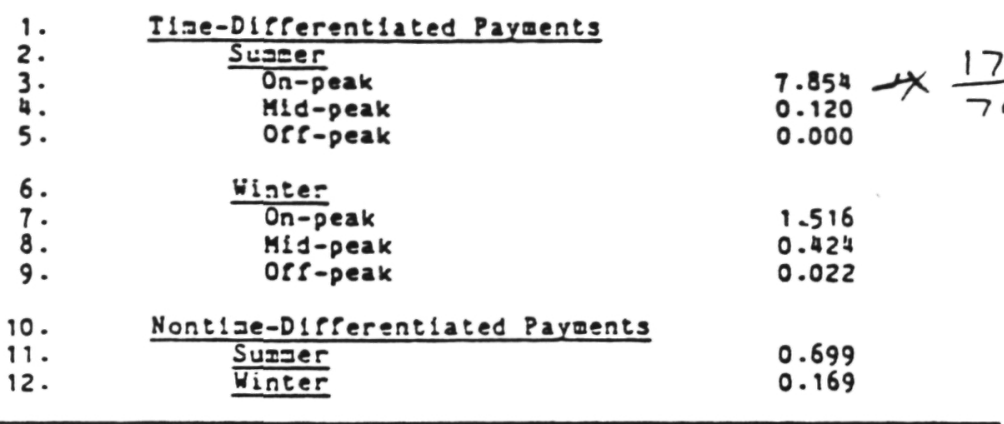

i/ Bases on Biblixid - year. (1984 Shortage Cosis)

${ }^{\prime}$ ' Inis Capacity Pay=ent Schetule is based on the deferral of combustion turbines and is to be upca:ec a: leas: biennialiy based on gerera: rate case data. The screswie Includes euture escalations of capltal costs and operation and mainterarcs costs.

ANMOLL CAPACITY-PA NEYT SCBEDULE POR STANDLRD OFFER NO. 2

FIRM POWER PORCBUSES EPPECTIVE FEBROLRI 1A, 1983

\begin{tabular}{|c|c|c|c|c|c|c|c|c|c|c|c|c|c|c|c|c|}
\hline \multirow{2}{*}{$\begin{array}{c}\text { LIne } \\
\text { No. }\end{array}$} & \multirow{2}{*}{$\begin{array}{l}: \\
\vdots \\
:\end{array}$} & \multirow{2}{*}{$\begin{array}{c}\text { Year of } \\
\text { In } 1 \text { : :al Del } 1 \text { inery }\end{array}$} & \multirow[b]{2}{*}{ : } & \multicolumn{13}{|c|}{$\begin{array}{l}\text { S/kid-lear } \\
\text { act Terg (y }\end{array}$} \\
\hline & & & & 1 & $:$ & 5 & $:$ & 10 & $:$ & 15 & $:$ & 20 & $:$ & 25 & $:$ & 30 \\
\hline $\begin{array}{l}1 . \\
2 . \\
3 . \\
4 . \\
5 . \\
6 .\end{array}$ & & $\begin{array}{l}1983 \\
1984 \\
1985 \\
1986 \\
1997 \\
1988\end{array}$ & & $\begin{array}{r}70 \\
76 \\
81 \\
87 \\
94 \\
101\end{array}$ & & $\begin{array}{r}80 \\
86 \\
93 \\
100 \\
107 \\
117\end{array}$ & & $\begin{array}{r}92 \\
100 \\
108 \\
117 \\
127 \\
137\end{array}$ & & $\begin{array}{l}105 \\
113 \\
122 \\
131 \\
142 \\
153\end{array}$ & & $\begin{array}{l}114 \\
123 \\
132 \\
143 \\
154 \\
166\end{array}$ & & $\begin{array}{l}121 \\
131 \\
141 \\
152 \\
163 \\
176\end{array}$ & & $\begin{array}{l}127 \\
137 \\
147 \\
158 \\
170 \\
184\end{array}$ \\
\hline
\end{tabular}

Conversion to Monthly Payments (Apollcable for Payment Option 2 Only): The rollowiag factors are currently et'ective Cor conversion of the adove annual capacity values to montnly payments by tlme period of dellvery. These conversion factors will be subject to perlodic change as approved by the CPUC.

$\begin{array}{lll} & \text { Sumiger } & \text { winter } \\ \text { On-Peak } & .13125 & .02094 \\ \text { Mid-Peak } & .00267 & .01054 \\ \text { Orf-Peak } & .00000 & .00127\end{array}$

\footnotetext{
This Capacity-payment Schedule ls based on the deferral of combustlon turblnes and ls to be updated at least blennfally based on the general race case caia. The Capaclity-payment Scnedule includes Cuture escalations of capltal costs, operation and malntenance costs, and has been translated Into a levelized-serles payaent for the tera of the contract. Prices In the above schedule are given in dollars by year of dellvery (1.e.. the 1984 ilne shows dollars to be pald for all years of the contract tera for contracts giarting ln 1984).
} 


\section{Southern California Edison Company}

P D DOX Doo

22 4 WALNUT GAOVEAVENUE

MOSEMEAD. CALIFORNIA 1770

AVOIDED COST PAYMEMT SCHEDULES

POR COCEMEHATIOU AMD SMLL POYEX PRODUCERS

LONC-TERM POUER PURCHASE

STANDARD OFFEH NO. 4

February 1984

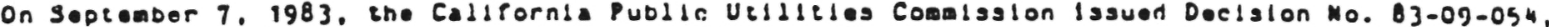
plaoing into orreos, on an lnterim basle, the Long-tore Puronase Contraot (Standald Orfer Mo. A) sor

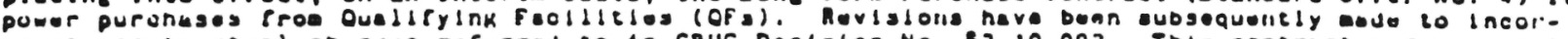

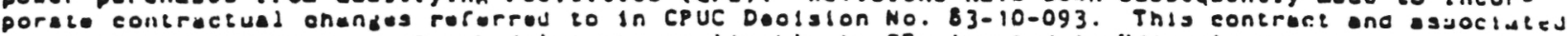

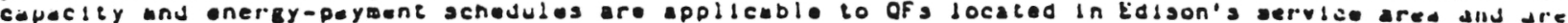

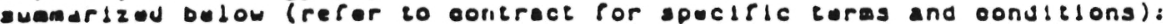

\section{Contract Tere}

- Minisum of 15 years; axlaue of 30 years

- Of eust be in operalion withln flve yeargepter contract execuljon

\section{Payeent Provlgtong}

Payments for capacley and energy dellvered to Edlson wlld be alde on a perforaunce basls and wlid be that odsterentaleo.

- The approprlate capacley and energy-payment schedules uld be ostabllohed at the elac or coneract execution ane will remaln in erfect for the specifled payaune perlod. The enclosel

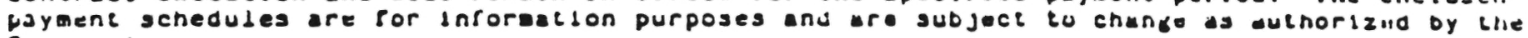
Comedgalon.

- Sindard Orfer Mo. A provldes for two capacliy-payment optlons and three eliergy-payeent

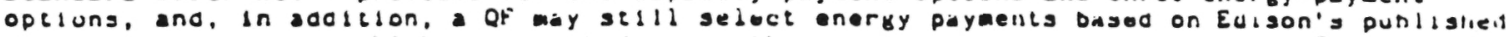

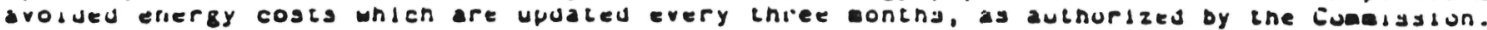

\section{Capacity Payeent Optlong (Iwo)}

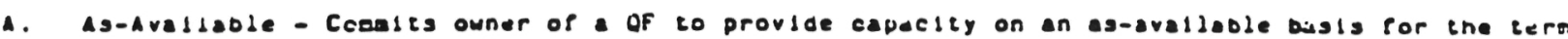
or the contract.

Payment: of or any technology can select

- As-avaldade Payeent Schedule ror Standard Orfer No. 1; or

- Forecaje of As-avaldable Capjcity Payment Schedule - Length of payent period depenus on ine coulrucl tere.

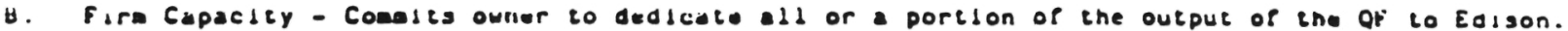

- Capaclity Payeents based on a Op's energy production or output (capacliy tactor) dellvered

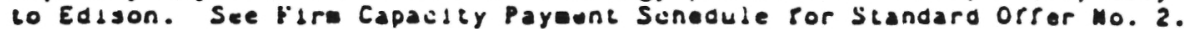

- Minjeua perforance requlrenents have been established. A of falding to eef these

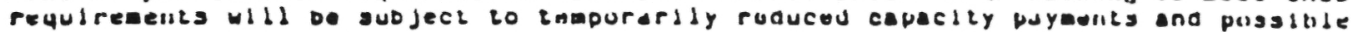

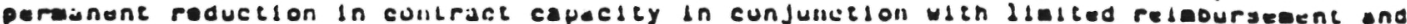
replacevent payaenty to Eabsun.

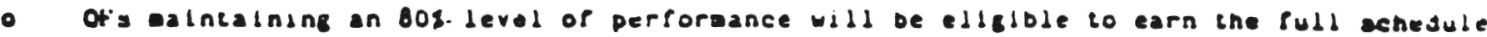
paybeus.

- A Ur can recelve bunus capacity payments of up to l8s above Edison's avoldea eapucily cost

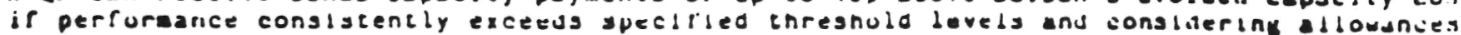
rur rorced and sclioduled ouliues.

- Payeent option applicable to any uf techiology.

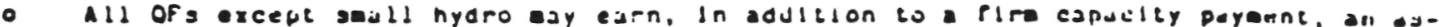

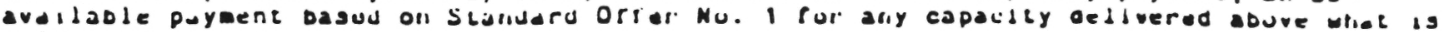
delivered us rire. 


\section{ORIGINAL PAGE IS \\ OF POOR QUALITY}

AVOIDED COST PA TMEMT SCHKDULES

TOR COGEMERATIOM AMD SMLL POMEA PRODUCXRS

\begin{tabular}{l} 
LONC-TENM POUER PURCHASE \\
STANDARD OFFEA NO. \\
\hline
\end{tabular}

February 1984

(conts nued)

\section{Energy-Payent Optlons (Itree)}

1. Forecast of Annual Marginal Cost of Energy (See enclosed achedule)

- A Of eay aelect thls payeone schodule or peyeent per wh besed en Inereaenta of 20 of inls rorecast price, witn bajance of price based on publdabed avelded energy costs.

- Length of enls payeont derlod depends on the oontract tore; payeent for balance of tera basad on published avolded oneray costs.

- Payaent option ls avallable to any technology. Oll/natural cas cogeneratora are llabted to payeent per kWh besed on 208 of the forecast price and dos of lhe publishes avoloud enersy cost.

2. Leveldzed Forecast of Annual Marginal Cose of Energy (Seo enolosed achedule)

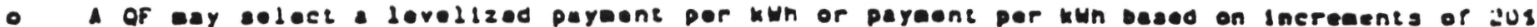

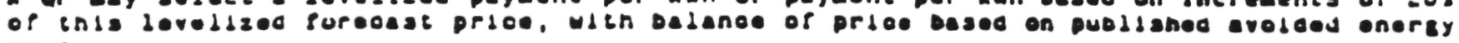
ooses.

- Security ls required por any energy payaents attributed to the elfference between leveldzed price and forecial price.

- Lenger or levelized payaens perlod depends on the eontracs tere; payeene for belance of cors based on publdshed avolded energy costa.

- Minteue derforeance requirements have been establighed. Fallure to perpore eay require the

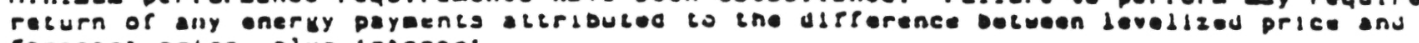
rorecast price. plus dnterest.

- Payeent oplion lo axaldable to ony cechnobogy except old/natural cas coceneracorg.

3. Forecast of Increaentad Energy Rates (Jee enclosed scneduje)

- Energy payeent price ls based on a formula, unich, in alapliflec pore por lldustrukion purposes, is as roldows

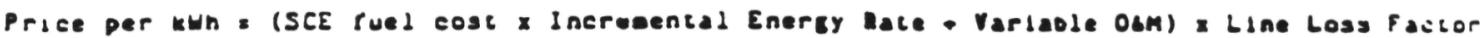

Ald values in the ruraula are subject to periodic upate (a new orlce to reflect seasongl

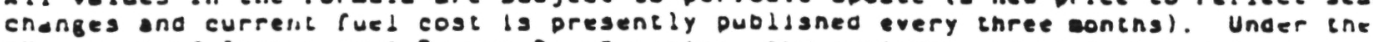

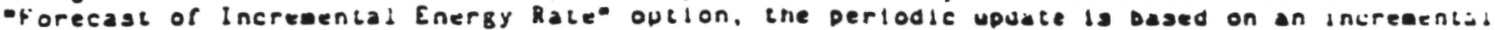

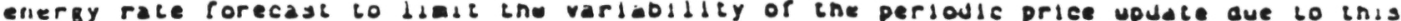
ractur.

- A Of ay also specify a ploorfeelding range in 100 Btu/kwh ateps above and belou the increvental enerky race forecast vabues. Thls aldous soov varlabllity ln the periogla prise

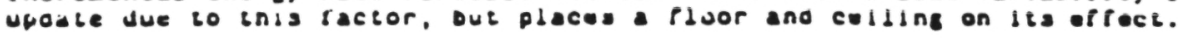

- Tnls increaental energy rate la appldeable tnrough 1997. Tberearter, tbe energy-payeent price will be the nurad perlodic uplate vadues.

- Payeons option la avaldable tu any or ecennolocy.

If you require asstsince in uging the encloged capacticy or onergy-payeent gehedules or would like

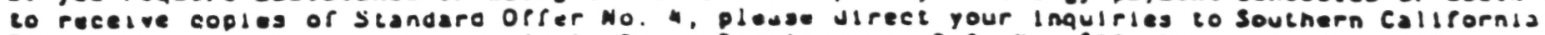

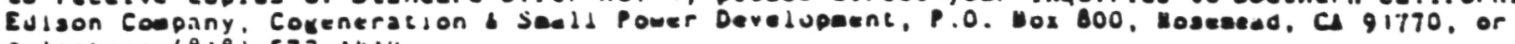
sedeplione (818) 573-1414. 
CaPACSTI OPTION A

Sebocule for

Se-4VIlable

Capaelty Pagent

(See eest page for Opldod $(12)$

\section{AMUOLL CIPACISI-PANENT SCEDDOLE PON STIMDARD OPPER NO. 2}

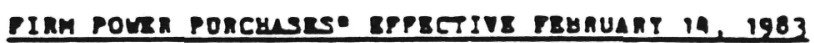

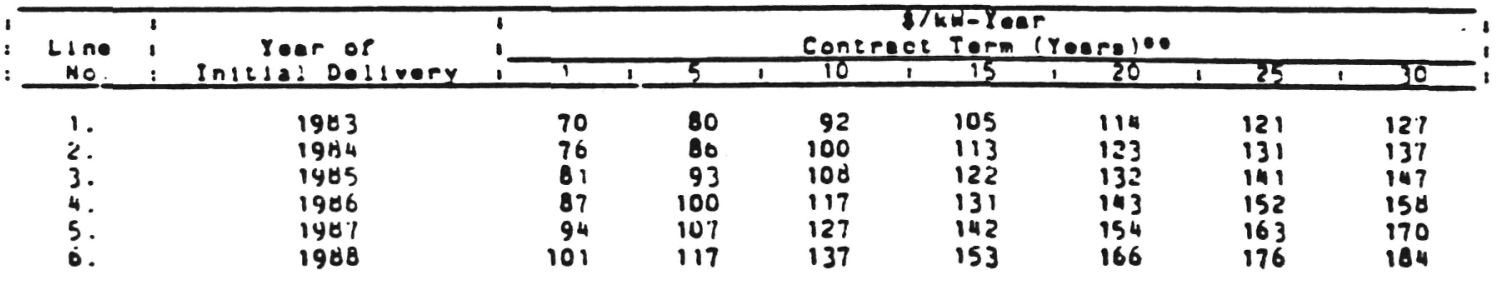

CIPACSYY OPTIOE:

Sohedude Por

Pitr capacily

Poreons

Colivergion to monelily Payments (Applicable for Payment Oution 2 Only): The foldowing

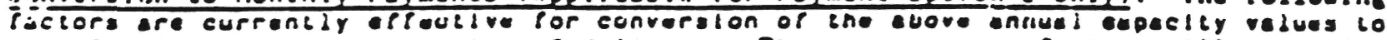

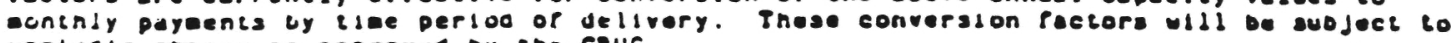
verlooje change as approved oy the CPuC.

$\begin{array}{lll} & \text { Suener } & \text { ulncer } \\ \text { On-Peak } & .13125 & .02094 \\ \text { MId-Peak } & .00207 & .01054 \\ \text { Orf-Peak } & .00000 & .00127\end{array}$

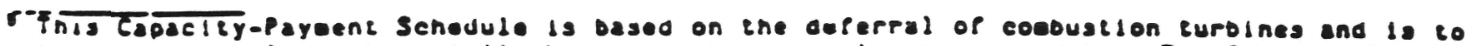
De upuated at beagt bienniajly bused on the cenerad rate case data. Ine Capucley-papent Echedule Includes future escalations of caplisal costs, operation end aintenance costs. ind has been trangloted inco devellzed-geries payeent por the tere of the contract.

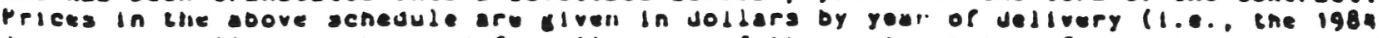
lime allows dollars to be pale for all years of the cuntruct tere for contracts atartine in 1984).

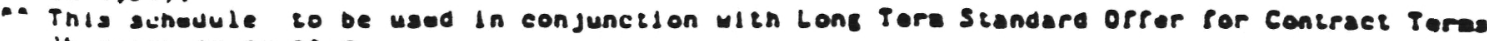
is years or greater. 


\section{SOUTUKRM CALIPORMIA SDISON COMPAXT}

LOMC TEMM STAMDARD OPFER

CAPACITI PATMENT SCIIXDULE - TONECAST OF

AS AVAILABLE CAPACITY I'

\begin{tabular}{|c|c|c|c|}
\hline $\begin{array}{l}\text { LIne } \\
\text { No. }\end{array}$ & rear & $\begin{array}{r}\text { As avalladle Capac } \\
\text { (g/Kw-yeur) }\end{array}$ & 'y \\
\hline 1 & 1984 & 76 & CNACITT OPTION $\perp_{2}$ \\
\hline 2 & 1985 & 1 & sebecule por \\
\hline 3 & 1986 & 87 & Torocest of As-Avallable \\
\hline 4 & 1987 & 94 & Capadty Pagroot \\
\hline 5 & 1988 & 101 & \\
\hline 6 & 1989 & 109 & \\
\hline 7 & 1990 & 117 & \\
\hline 8 & 1991 & 126 & . \\
\hline 9 & 1992 & 148 & \\
\hline 10 & 1993 & 158 & \\
\hline 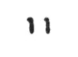 & 1994 & 169 & \\
\hline 12 & 1995 & 180 & \\
\hline 13 & 1996 & 194 & \\
\hline 14 & 1997 & 206 & \\
\hline 15 & 1998 & 221 & \\
\hline
\end{tabular}

SELSOMAL IINE OF DELIVERI

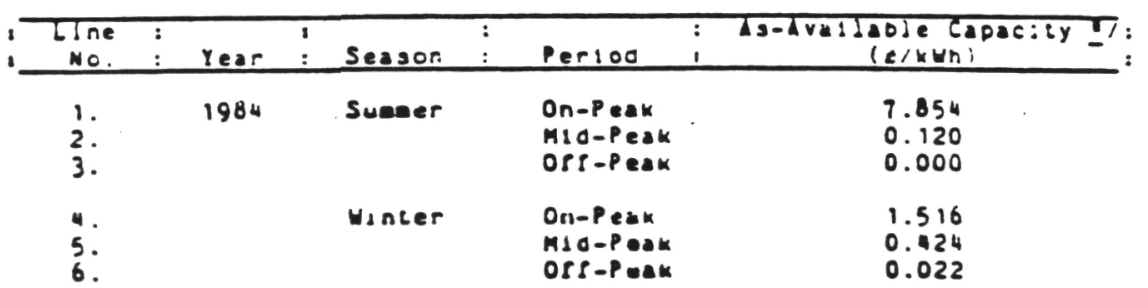

1 Inls porecast to be used In conjunction witn Capacity Paraent Oplion $A$.

$2^{\prime}$ The annual as-avallable eapacity (\$/ku-yr) w1ld bo convertec to a seasonal tiac-or-dedivery (c/kwh) value iniet lo conslatent with as-avaldable tiou-op-dejdrery rutes currentiy outhorlzed oy the Coaliasion for lvolded as-Avaddable Capacily.

-I In subacquent years, the annual as-avaljable capacity (s/ku-yr) wild be converted to aesonad tive-of-dedivery (c/kun) value that la conglatent with as-ovaliable tiasor-delivery ratea currontly authorlaed by the Coaviasion for avolued asuallable Capacily. 
BUEACT PA MOKT SCHEDULE - PORECAT OP AMUULL MARCIHAL

COST OP EMERCT I/

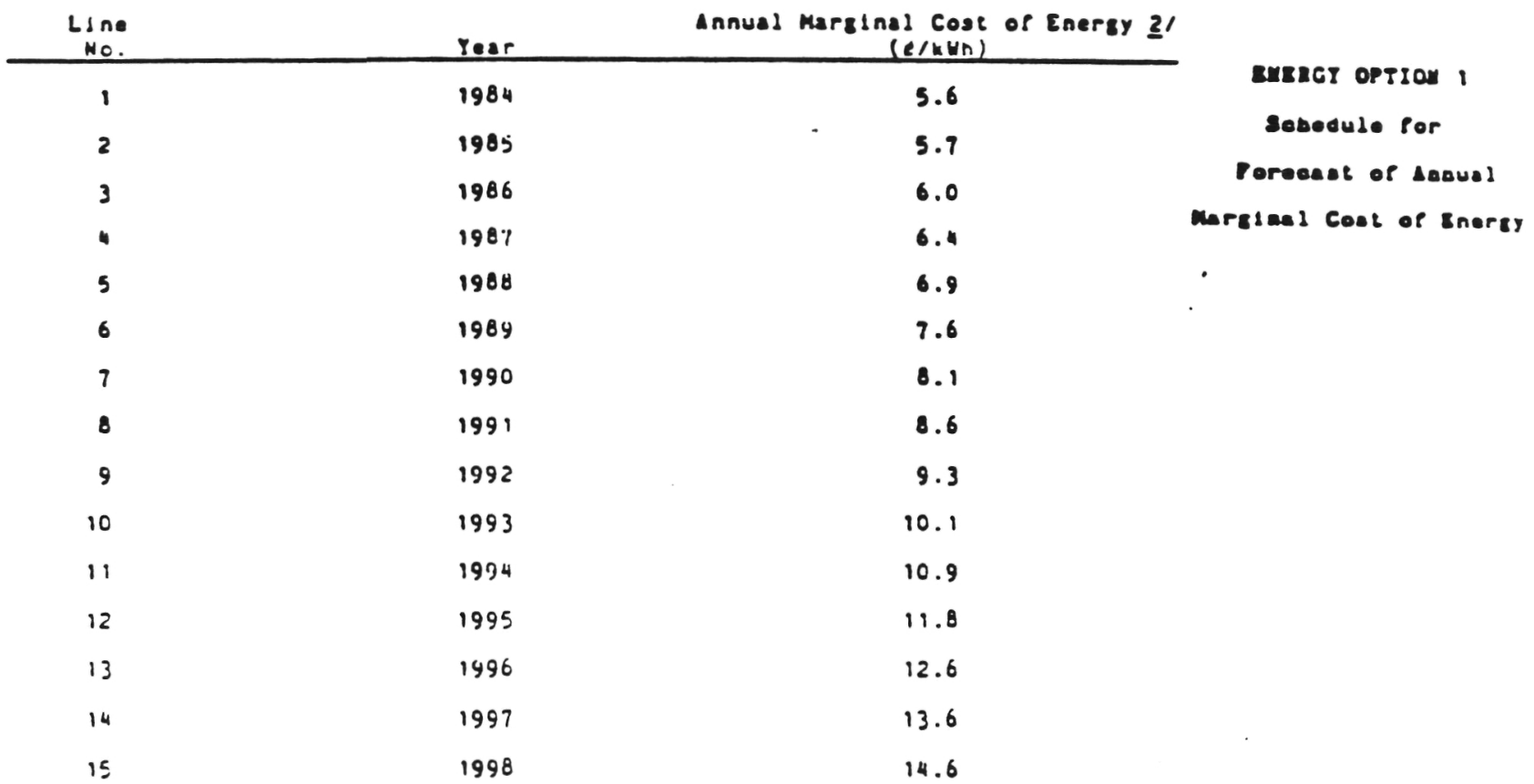

SELSOMLL TIME OP DELIVERT

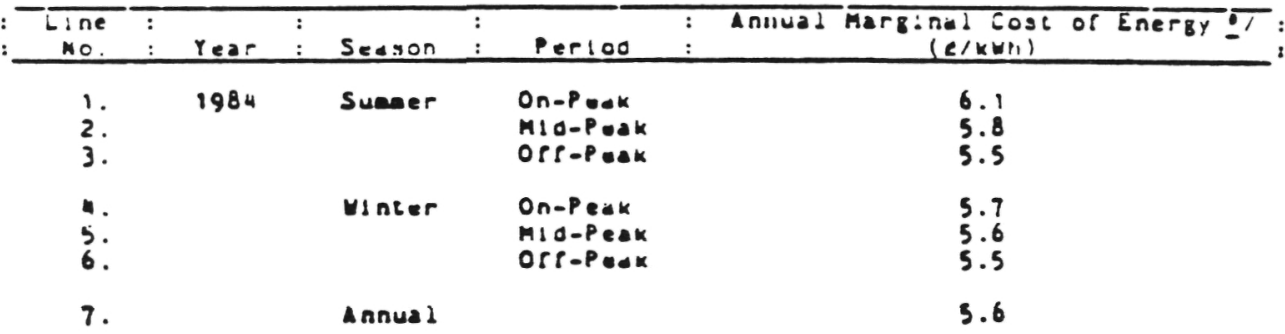

1' Inds porecase to be used in conjuncelon wlen Enerzy Payeent Option 1 .

2' Tho annusl enorgy payeents in the table wlll be converted to gedsond tiac-of-delivery enarty payaent races that are consigtent with the tlop-or-dolivery ratas eurrently outhorbzed

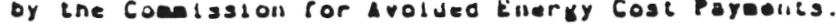

$\because$ In subgequent yoarg, the onnual energy payaents in tho table wlll be converied to sedsolled thee-of-oelluery unuryy payoeile

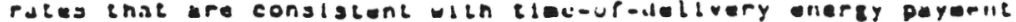
rales eurrontly authorlized by the Camisalon for Avulded Enerdy Cuse Payouncs. 


\section{SOUTHEAM CALIPORHIA ROISON COMPAXY}

LONC TKAM STAMDARD OPPER

EUERCY PA MEYT SCHEDULX - LEVELIZSD PORKCAST OP MRCIMAL

COST OP ЕMKHCT I'

\begin{tabular}{|c|c|c|c|}
\hline $\begin{array}{l}\text { Line } \\
\text { No. }\end{array}$ & $\begin{array}{l}\text { Indelal } \\
\text { yeor of } \\
\text { Delivery }\end{array}$ & $\begin{array}{l}\text { S-rear } \\
\text { Levedized } \\
\text { Porecast } 21 \\
\text { (e/kun) }\end{array}$ & $\begin{array}{l}\text { 10-year } \\
\text { Leveldzed } \\
\text { Forecast } 21 \\
\text { (e/KUn) }\end{array}$ \\
\hline 1. & 1984 & 6.0 & 6.9 \\
\hline 2. & 1945 & 6.4 & 7.3 \\
\hline 3. & 1986 & 6.8 & 7.9 \\
\hline 4. & 1987 & 7.3 & 8.5 \\
\hline 5. & 1988 & 7.9 & 9.1 \\
\hline 6. & 1989 & 8.6 & 9.8 \\
\hline
\end{tabular}

EURAGI 0esion 2

Sabodule For

Lovellzed Forweas of

Leould Mereleal Coet

or Earey

\section{SELSOMLL TIRE OP DELIVERT}

\begin{tabular}{|c|c|c|c|c|c|c|c|c|c|c|}
\hline $\begin{array}{l}\text { L I ne } \\
\text { No. }\end{array}$ & $\begin{array}{l}1 \\
\vdots \\
1\end{array}$ & $\begin{array}{l}\text { Indelal } \\
\text { Year of } \\
\text { Delivery }\end{array}$ & $\begin{array}{l}1 \\
1 \\
1\end{array}$ & Secson & $\begin{array}{l}1 \\
\vdots \\
1\end{array}$ & Perlod & $\begin{array}{l}1 \\
\vdots \\
\end{array}$ & 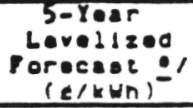 & $\begin{array}{l}1 \\
1 \\
1\end{array}$ & $\begin{array}{l}\text { To-year } \\
\text { Levediaed } \\
\text { forecase } \\
\text { (elukn) }\end{array}$ \\
\hline $\begin{array}{l}1 . \\
2 . \\
3 .\end{array}$ & & 1984 & & Suneer & & $\begin{array}{l}\text { On-Peak } \\
\text { Mld-peak } \\
\text { off-peak }\end{array}$ & & $\begin{array}{l}6.5 \\
6.2 \\
5.9\end{array}$ & & $\begin{array}{l}7.5 \\
7.1 \\
6.8\end{array}$ \\
\hline 5. & & & & Winter & & $\begin{array}{l}\text { On-peak } \\
\text { mid-Peik } \\
\text { ort-poak }\end{array}$ & & $\begin{array}{l}6.1 \\
6.0 \\
5.9\end{array}$ & & $\begin{array}{l}7.0 \\
6.9 \\
6.1\end{array}$ \\
\hline 7. & & & & Annua: & & & & 6.0 & & 6.9 \\
\hline
\end{tabular}

1 Thls rorecast to be used in conjunction with Enercy Paraent Opiton 2 .

If The annual energy payaents in the table wlll be converiod to

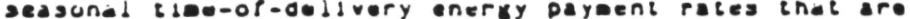

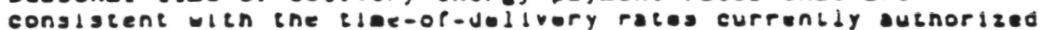

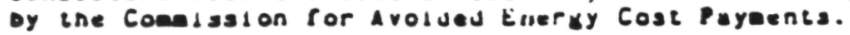

-' In subsequent yearg, the annual energy payeents in ine table ull be converted to geisonal tiae-op-delivery energy payeent rates that are conslatent with clae-or-dellvery energy dayaent rubes currentiy authorbzed by the Coestasion for avcloed inergy Cost payeencs. 
ORIGINAL PAGE IS

OF POOR QUALITY

\section{SOUTHRRE CALIPOREIL BDISON CORPINY}

LONG TERM STANDARD OYFBR

EUERGT PLTEET SCHEDOLE - PORBCAST OP INCREMBNTAL

ENERCI MATES (IER) I'

\begin{tabular}{|c|c|c|}
\hline $\begin{array}{l}\text { LIne } \\
\text { No. }\end{array}$ & Year & $\begin{array}{c}\text { Annual } \\
\text { IER } 2 / \\
\text { (Btu/kWh) }\end{array}$ \\
\hline 1. & 1983 & 9400 \\
\hline 2. & 1984 & 8930 \\
\hline 3. & 1985 & 8920 \\
\hline 4. & 1986 & 8870 \\
\hline 5. & 1987 & 8900 \\
\hline 6. & 1988 & 8900 \\
\hline 7 . & 1989 & 9030 \\
\hline 8. & 1990 & 8880 \\
\hline 9. & 1991 & 8750 \\
\hline 10. & $1992-1997$ & 8750 \\
\hline
\end{tabular}

SEASOYAL TIME OF DELIVERY

\begin{tabular}{|c|c|c|c|c|c|c|c|c|}
\hline $\begin{array}{l}\text { Line } \\
\text { No. }\end{array}$ & $:$ & Year & $\begin{array}{l}: \\
\vdots\end{array}$ & Season & : & Period & 8 & $\begin{array}{c}\text { Annuai IEA } \\
(B \text { Eu/kWn) }\end{array}$ \\
\hline $\begin{array}{l}1 . \\
2 . \\
3 .\end{array}$ & & 1984 & & Summer & & $\begin{array}{l}\text { On-Peak } \\
\text { Mld-Peak } \\
\text { orf-Peak }\end{array}$ & & $\begin{array}{l}9.770 \\
9.240 \\
8.740\end{array}$ \\
\hline $\begin{array}{l}4 . \\
5 . \\
6 .\end{array}$ & & & & Winter & & $\begin{array}{l}\text { On-Peak } \\
\text { MId-Peak } \\
\text { Off-Peak }\end{array}$ & & $\begin{array}{l}9,020 \\
8,990 \\
8,710\end{array}$ \\
\hline 7. & & & & Annual & & & & 8,930 \\
\hline
\end{tabular}

1 Inls sorecast to be used in conjunction with Energy Payment Option 3 .

2' The annual sorecast of Incremental energy rates in the table w1ll be converted to time-of-dellvery rates proportional to the current Coedsslon approved ilae-op dellvery rates.

-I In subsequent years, the annual forecast of Increaental energy rates In the table wlll be converted to tise-op dellvery rates proportional to the current condasionapproved tace-op-dellvery races.

$$
\mathrm{D}-14
$$

RERGI OPTIOA 3

Scbedule Por

Forecast of Increnental

Eaerge Rates 
SCE STANDARD CONTRACT

LONG TERM POWER PURCHASE

POWER PURCHASE CONTRACT

BETWEEN

SOUTEERN CALIFORNIA EDISON COMPANY

AND

Seller

DOCUMENT NO.: $1505 C$

EEFECIIVE DAIE: Septe-ze: 7, i $9 E j$

REVISED: MaY 4, 1984 
SCE STANDARD CONTRACT

LONG-TERM POWER PURCHASE

TABLE OF CONTENTS

SECTION TITLE

PAGE

1 PROJECT SUMMARY

GENERAL TERMS AND CONDITIONS

2 DEFINITIONS

2.1 Adjusted Capacity Price

2.2 Appendix A.I

2.3 Appendix A.2

2.4 Appendix A.3

2.5 Appendix $B$

2.6 Appendix $C$

2.7 Appendix D

2.8 Capacity Payment Schedule(s)

2.9 Cogeneration Facility

2.10 Commission

2.11 Contract

2.12

2.13

2.14

2.15

2.16

2.17

2.18

2.19

2.20

2.21

2.22

2.23

2.24

Contract Capacity

Contract Capacity Price

Contract Term

Current Capacity Price

Edison

Edison Electric System Integrity

Emergency

Energy

Firm Operation

First Period

Forced Outage

2.25

Generating Facility

Generator

2.27

2.28

Incremental heat Rate(s)

Interconnection Facilities

2.29

Interconnection Facilities Agreement

KVAR

2.30

2.31

2.32

2.33

Operate

Operating Representatives

Parties

Party

2.34

Peak Months

2.35

Point of Interconnection

Project

2.36 Protective Apparatus

2.37 Qualifying Facility

2.38 Second Period

2.39 Seller

2.40 Seller's Facility

2.41

2.42

Small Power Production Facility

2.43

Standby Demand

Summer Period 
SCE STANDARD CONTI ..CT

LONG-TERM POWER PURCHASE

TABLE OF CONTENTS

\section{SECTION TITLE}

PAGE

2.44 Tariff Schedule No. TOU-8

2.45 Uncontrollable Forces

2.46 Winter Period

3 TERM

4 GENERATING FACIIITY

5 OPERAIING OPIIONS

6 INTERCONNECTION FACILITIES

7 ELECTRIC LINES AND ASSOCIATED EASEMENTS

8 METERING

9 POWER PURCHASE EROVISIONS

10 PAYMENT AND BILLING PROVISIONS

11 TAXES

12 TERMINATION

13 LIABILITY

14 INSURANCE

15 UNCONTROLLABLE FORCES

16 NONDEDICATION OF FACILITIES

17 PRIORITY OF DOCUMENTS

18 NOTICES AND CORRESPONDENCE

IY PREVIOUS COMMUNICATIONS

20 NONWAIVER

21 SUCCESSORS AND ASSIGNS

22 EFFECT OF SECTION HEADINGS

23 GOVERNING LAW

24 MULTIPLE ORIGINALS

SIGNATURES 
APPENDIX E

MARTINI ENGINEERING

"OVERVIEW OF STIRLING MACHINE DEVELOPMENT AND APPLICATIONS" 


\section{MARTINI ENGINEERING}

2303 Harris, Richland, Washington 99352

Telephone (509) 375-0115

\section{OVERVIEW OF STIRLING MACHINE DEVELOPMENT AND APPLICATIONS}

by

DR. WILLIAM R. MARTINI

Presented at

19th Annual

Intersociety Energy Conversion

Engineering Conference

San Francisco, California

Plenary Session

August 24, 1984 


\section{OVERVIEW OF STIRLING MACHINE DEVELOPHEAT AND APPLICATIONS \\ by \\ Dr. William R. Martint \\ Martini Engineering \\ 2303 Harris Ave. \\ Richland, WA 99352 \\ (509) 375-0115}

\section{ABSTRACT}

A brief history, list of advantages, and explanation of how stirling machines work is given. Stirling machine technology development is mentioned, but the main part of the paper is devoted to a description of Stirling machines roughly in the order that they have or will enter the market. The stirling machine is a well established product as a cryogenic refrigerator. As an engine it is moving into production as a solar thermal power source, as a transportable power source, as an engine to power heat pumps, and as an unattended electric generator. Important but long range development programs are described to apply the Stirling engine to automobiles and trucks, to space electric power, to submarine propulsion, to power a rice huller in the third world, and to power an artificial heart. Other possible applications not now under active development are mentioned. A guide to further sources of information is given.

\section{INTRODUCTION}

For many years now the IECEC has been the world's only annual meeting of Stirling engine enthusiasts. This year under the able organizational skill of Dr. Colin West, we have 51 papers that made the transactions. For the first time we have had to go in parallel session with ourselves. Outside of aerospace we are the largest component of the IECEC. Many of us who regularly attend the IECEC appreciate the chance to read about the latest in other competing forms of energy conversion even though the task of keeping up with what is going on in Stirling engines is all consuming at the meeting. Because of my involvement on the Steering Committee of the IECEC, I quite often get asked the question why an engine that the person has never heard of is 80 prominent in the IECEC program. The charter of the IECEC is to furnish a forum for things novel and advanced in energy conversion. In energy conversion you will hear about it first at the IECEC.

Our group of enthusiasts have each analyzed the properties of the Stirling engine. They have seen unique possibilities in the Stirling engine that they feel needs developing. This intrepid group has not been discouraged by negative judgements of the business and system analysts that have resulted in the cancellation of a number of technically successful programs. They have persevered. Now it appears that there are a number of real applications for the Stirling engine that will justify our faith in investing our professional careers in its development.

Our group is quite diverse in character. We have professors of respected engineering schools throughout the world. We have people with little engineering training but a lot of common sense who just like to build things. Two years ago in Reading, England we had an international meeting entirely on the Stirling engine. Nineteen papers were presented, mostly from Europe. This year we had an international meeting in Shanghai, PRC. Forty seven papers were 
presented mostly from the Far East. Two years hence there will be an intermational meeting in Rome, Italy. This year of the 51 papers presented, 27 came from the United States, 8 from the United Kingdom, 4 from Canada, 3 from Japan, 2 each from China and Italy, and 1 each from France, Mexico, the Netherlands, South Africa, and Yugoslavia. However, these papers only represent the part of our group who would like to share information. A very large commercial effort based in Sweden is busy writing product descriptions and sales brochures instead of engineering papers.

I will now give a brief history, a superficial description of how the machine works, and outline its advantages. I will describe the current Stirling machine products, the long range development programs, and the possibilities for application of the Stirling machine. Finally the sources for additlonal information will be outlined.

\section{BRIEF HISTORY}

Although thi main focus of this paper is to relate what is going on in Stirling engines now, it is important to have some idea where Stirling engines are coming from. The term "Stirling Engine" was started by Dr. Roelf Meifer of the Philips Laboratories in Eindhoven, the Netherlands in 1953. He did this to honor the Reverend Robert Stirling who patented this type of machine in 1816. Also the old term, air engine or hot air engine, no longer applied since the engines and cryocoolers then in development were using hellum or hydrogen instead of air. Particularly in the late $1800^{\prime} \mathrm{s}$ and early $1900^{\prime} \mathrm{s}$ the air engine was a modest commercial success. Many thousands of these air engines were built. They were used for pumping water, fanning the air, and other low power applications in the home and shop. They were noted in the era of frequent boiler explosions for their safety, quietness, and ease of operation. They were also noted for their large size and welght since they lnvariably operated on air with a minimum pressure of one atmosphere. When the electric motor and the small gasoline engine came in, the air engine ceased to be sold except as a small demonstration engine. Some are still in active operation.

In the late $30^{\prime} \mathrm{s}$ the N. V. Philips Company was casting about for a sultable generating machine to power radio equipment in out of the way places, since radios were their main business. They greatly improved the old air engines by applying modern engineering and materials technology. They built a small and silent electric generator heated by a kerosene flame for a radio. This would have been a good product if transistor radios had not been introduced. Today with higher power requirements for television this would have had a market. They also built a compact $200 \mathrm{w}(\mathrm{e})$ self contained electric generator running on diesel fuel. About 50 of these were made.

In 1953 the Philips management decided to cancel the heat engine work and concentrate on the cryocooler. The cryocooler continues today as an important product line. The engine program was reduced to one man, Dr. Meijer. Fron this very small re-beginning, Dr. Meijer made some basic changes in approach and made some very good engines. These engines attracted interest and major development efforts. General Motors, under license, worked on it from 1958 to 1970. Ford Motor Company worked on it from 1972 to 1978 . In 1968 United Stirling of Sweden and the M.A.N.-MWM Development group in Germany purchased licenses from Philips and started development. The German group has always been-secretive and-has-apparently dropped out. The Swedish company and affillates in the United States is now owned by FFV, a Swedish government company. 
Although Philips stopped work on Stirling engines in 1980, the Philips technology lives on in its licenses and in Stirling Thermal Motors of Ann Arbor, Michigan which was founded by Dr. Meljer when he retired. Now Stirling Motors Europe has been organized to build and sell the Stirling engine recently designed by Dr. Meijer.

In a special place among developers of Stirling engines is Mechanical Technology Inc. (MTI) of Latham, NY. MTI started as a spin-off from GE as an expert in gas bearings. They have agressively branched out into other promising technical opportunities, including Stirling engines. They now spend an annual budget of more than $\$ 15$ million in the Stirling engine area. This money includes a major subcontract to United Stirling of Sweden. From 1975 to 1978 MTI engaged Sunpower to learn about free piston Stirling engines. At one time there were to be two automotive stirling development programs. The first one was with the Ford Motor Company with N. V. Philips as the engine subcontractor. MTI won the second team contract using United Stirling of Sweden as the engine subcontractor. When Ford cancelled all stirling engine work in 1978, MTI was left with the only program which was for $\$ 90$ million and was to run from March 1978 to November 1984. MTI is the largest Stirling engine development organization in terms of effort managed and is positioned in both the kinenatic and free piston Stirling engine areas. Although it is true that MTI has been able to draw technology from other companies, they have added their own innovations and made it uniquely theirs.

Entirely independent of the Philips or United Stirling technology, other major centers of Stirling engine development have sprung up. Sunpower Inc. of Athens, Ohio has been in operation since 1964 if its roots in Ohio Univeristy are included. Energy Research and Generation has been interested in Stirling Engines since 1973. Two programs to develop the Stirling engine to power an artificial heart have been going since 1968. Schools that have been active in Stirling engine research include Massachesetts Institute of Technology, University of Witwatersrand in South Africa, University of Tokyo, Tokyo Institute of Technology, and Meiji University in Japan, and Cambridge, Reading, and Manadon in the United Kingdom. and the University of Calgary in Canada. Government laboratories in the United States active in the Stirling engine development include NASA-Lewis, Oak Ridge and Argonne National Laboratories, and the Jet Propulsion Laboratory. The list is growing. Individual contributors continue to be important. In fact, all the interest in the schools started as the interest of an individual who then proceeded to build an organization.

In almost a separate world are the cryogenic refrigerator developers. There are many different ways of producing cryogenic temperatures. Only some of them are Stirling machines or are closely related. The Philips family of companies has already been mentioned. U. S. Government agencies active in this area are:

1. Flight Dynamics Laboratories, Wright-Patterson Air Force Base, Ohio.

2. U. S. Army Night Vision Laboratory, Fort Belvoir, Virginia.

3. Naval Engineering Laboratory, Washington, D.C.

4. Office of Naval Research, Washington, D.C.

5. Naval Weapons Research Laboratory, China Lake, California.

6. NASA-Goddard Space Flight Center, Greenbelt, Maryland.

7. Thermophysical Properties Division, National Engineering Laboratory, Boulder, Colorado. 
Commercial companies engaged in this area are for the gas liquifiers:

1. Netherlandse Philips Bedrijven B. V., Eindhoven, the Netherlands.

Commercial companies engaged in the infrared sensor cooler area are:

1. CTI-Cryogenics, Waltham, Mass.

2. Hughes Aircraft Co., Torrance, Calif.

3. Kinertics Inc., Tarzana, Calif.

4. Texas Instruments Inc., Dallas, Texas.

5. Magnavox Electro-Optical Div., Mahwah, New Jersey

6. Martin Marietta, Orlando, Florida.

7. Cryomech Inc., Jamestown, New York.

8. Air Products and Chemicals Inc., Allentown, Penn.

9. AiResearch Manufacturing Co., Phoenix, Arizona.

This is not a complete 1ist. In the cooler area this paper can only scratch the surface to indicate the depth of the technology in the Stirling machine area.

HOW IT WORKS

The reader is referred to the information sources referred to at the end of the paper to learn how the Stirling machine works in detall. The Stirling engine is a closed cycle heat engine. Its nearest relative is the closed cycle gas turbine. In the gas turbine, cold gas is compressed and hot gas is expanded and a counter flow economizer separates the hot part from the cold part of the engine. The working fluid continuously flows thru the compressor, economizer, heater, expander, back thru the ecomomizer, the cooler and then to the compressor again.

The Stirling engine uses pistons to shuttle one body of gas around. At each instant of time this gas occupies a hot space, a heater, a reversing flow regenerator, a cooler, and a cold space all at essentially the same pressure. The pistons see to it that compression takes place with as much of the gas as possible in the cold space. Then the pistons move the compressed gas thru the cooler, regenerator and heater to open up the hot space. This motion increases the pressure so that expansion from the hot space creates more work than the cold compression required. The pistons then move the expanded gas back thru the heat exchangers to start the cycle again. Figure 1 shows one way that this cycle works. There are others.

The cycle efficiency of the Stirling cycle is the same as the Carnot cycle which limits the efficiency of any heat engine. In theory, it is possible to add all the heat at the top temperature and remove it all at the bottom temperature and have a reversible means for moving the gas between the two temperatures. The area enclosed by this theoretically perfect cycle is much larger than the Carnot cycle for the same temperature ratio and displacement. Therefore, even with losses, high efficiency can be attained.

We can think of the Stirling engine as a trade off. We trade in the complex compressor and expander wheels of the gas turbine or the bulky and dangerous boiler, expander, water pump, and condenser of the steam engine for two simple pistons. However, we inevitably get back the necessity to design the heat exchangers for the most heat exchange with the least flow friction and 


\section{ORIGINAL PAGE IS \\ OF POOR QUALITY}

internal gas volume. We usually get back the necessity for sealing the mechanical spaces which need ofl from the heat transfer spaces which would be ruined by oil.

Figure 1. Essential Character of a Stirling Engine

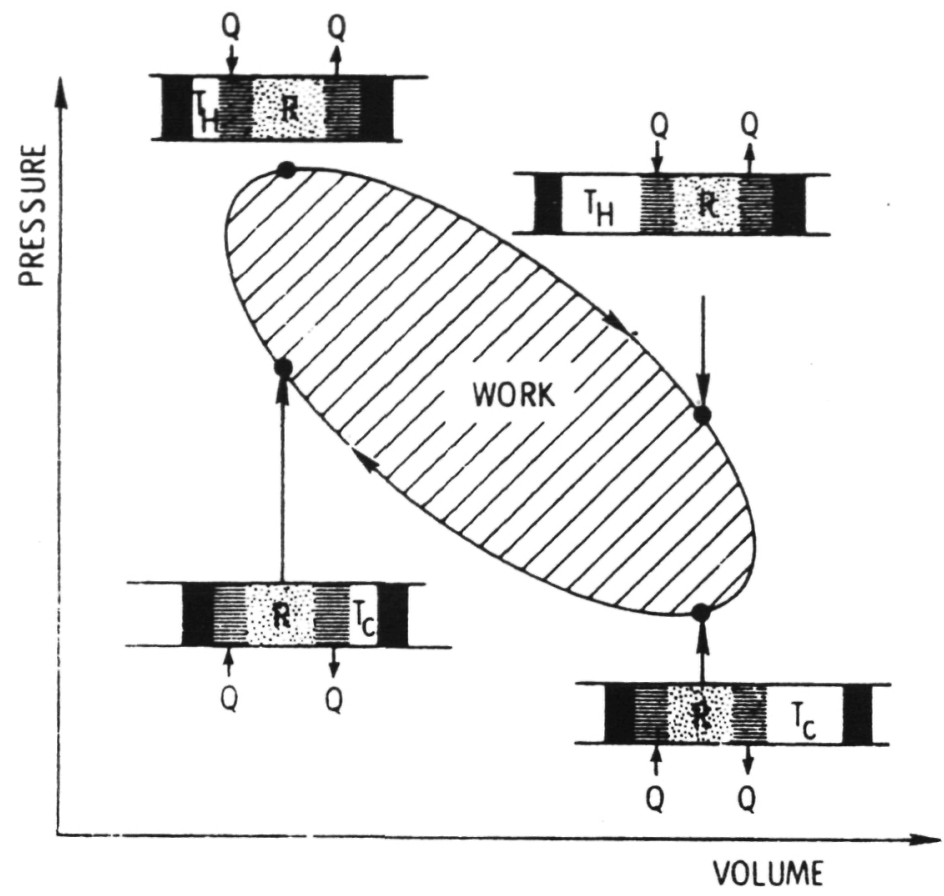

\section{POTEATIAL ADVANTAGES OP THE STIRLING ENGINE}

We think that the Stirling engine has some unique advantages that justify its development to compliment the other heat engines already in use. Some of the advantages over other heat engines are seen as follows:

LOW HOISE There are no explosions. There is no whine. Inherently the engine is silent. However, cranks and gears and fans do make noise that can be eliminated if necessary.

EXTERLAL hEAT INPUT This is no advantage at all for liquid or gaseous fuels because internal combustion engines work so well and usually pump their own fuel-air mixture. However, for solid fuels, solar heat, and stored thermal energy it is a definite advantage.

LOW POLUTION Like the Rankine cycle machine, external combustion of the fuel makes it possible to design and attain very low concentrations of noxious gases in the stack. This advantage is important because it is combined with a much higher fuel economy and a smaller size than has been possible for a Rankine cycle engine.

HIGH EPFICIBNCY This engine can operate at peak efficiency over the full temperature difference available. There is no need for topping or bottoming cycles.- Ceramics can be used to ratse the possible heat source temperature. Cold heat sinks really improve the engine performance. 
REVERSIBILITY Simply by running the engine backwards turns it from a heat engine into a heat pump. Also the change can be made internally without reversing the engine. Heat pumps and cryocoolers use the same technology as heat engines. Efficient energy storage devices to take the place of pumped hydro or batteries are possible.

HIGH RFICIENCY AT PART LOAD As power increases, efficiency peaks early and then falls off slowly. Machines that operate most of the time at part load, like automobile engines, would benefit.

EVEA, FIAT TORQUE Four cylinders is enough to give a very smooth torque in comparison to an internal combustion engine. The torque is nearly the same over a very wide range of engine speed.

LONG LIFE Extremely long life with no performance degradation have been demonstrated in several engines producing less than 100 watts of power. There is no reason why higher power engines cannot attain long life as well.

\section{SELF STARTING Free piston machines are usually self starting.}

BASILY CONTROLLED Rapid control is usually achieved by changing working gas pressure. Many other control methods are avallable.

\section{STIRLING MACHINE TECHNOLOGY}

This paper will not go into the many developments in the area of analysis and investigation of new and potentially useful forms of the Stirling machine. Suffice it to say that a lot is going on. Most of it is reported at the IECEC. Now anyone who takes the trouble to study the open literature can do a creditable job of developing his own Stirling machine on the first try. In the last few years many Japanese firms have done 1 t.

\section{CURREAT STIRLING MACHINE PRODUCTS}

CRYOGBMIC COOLBRS As has been mentioned Philips founded an important business in cryogenic refrigerators using the stirling cycle principle. These products fall into two classes, large size machines to produce liquid alr, oxygen, nitrogen, etc. and small size machines used as infrared sensors.

In the large size machines the $N$. V. Philips Cryogenics Department, at Eindhoven in the Netherlands supplies a wide variety of models. Table 1 describes these and gives the approximate number of machines that have been built so far.

To gain some appreciation for what these large cryogenic refrigerators are like, Figure 2 shows a picture and a cross section of the PLA-107, the current version of the original product. Note that piston (2) and displacer (3) move the working gas thru the heat input heat exchanger (6), the regenerator (5) and the heat output heat exchanger (4). The process goes reverse of that shown in Figure 1 to act as a refrigerator. The machine achieves full production 20 minutes after startup. 
Table 1. The N. V. Philips Cryocoolers

ORIGINAL PAGE IS

OF POOR QUALITY

Cat. No. Description

PLA 107S Compact Air Liquifier

PLN 106S Liquid Nitrogen Generator

$\begin{array}{ll}\text { PPG } 102 & \text { Cryogenerator } \\ \text { PPG } 400 & \text { Cryogenerator }\end{array}$

PLN $430(S)$ Liquid Nitrogen Generator

LOX 30 Compact Liquid Oxygen Plant

PP4 110

PPH 440 Hydrogen/Neon Recondenser

PGH 105 Hydrogen/Neon Recondenser

PLHe 104 Cryogenic Transfer System

MC 80

Helium Liquifier

$\mathrm{K}-20$ Miniature Cooler Compact Double Stage Cryogenerator

\begin{tabular}{lr} 
Capacity & Number built \\
$7-8$ liters $/ \mathrm{hr}$. & 200 \\
$0.8 \mathrm{~kW}$ at $77 \mathrm{~K}$ or & 2300 \\
$2.3 \mathrm{~kW}$ at $200 \mathrm{~K}$ & \\
$0.8 \mathrm{~kW}$ at $77 \mathrm{~K}$ or & 200 \\
$2.3 \mathrm{~kW}$ at $200 \mathrm{~K}$ & \\
$3.2 \mathrm{~kW}$ at $77 \mathrm{~K}$ or & 200 \\
$9.2 \mathrm{~kW}$ at $200 \mathrm{~K}$ & \\
$3.2 \mathrm{~kW}$ at $77 \mathrm{~K}$ or & 400 \\
$9.2 \mathrm{~kW}$ at $200 \mathrm{~K}$ & \\
2511 ters $/ \mathrm{hr}$. & 30 \\
$10 \mathrm{liters} / \mathrm{hr}$. & 40 \\
$40 \mathrm{liters} / \mathrm{hr}$. & 6 \\
$60 \mathrm{~W}$ at $20 \mathrm{~K}$ & 250 \\
$300 \mathrm{~W}$ at $77 \mathrm{~K}$ & \\
$3-24 \mathrm{itters} / \mathrm{hr}$. & 100 \\
0.5 - $1.0 \mathrm{~W}$ at $80 \mathrm{~K}$ & $50 *$ \\
$10 \mathrm{~W}$ at $20 \mathrm{~K}$ and & $40 *$ \\
$20 \mathrm{~W}$ at $80 \mathrm{~K}$ & \\
\multicolumn{3}{c}{ TOTAL } & 3816
\end{tabular}

* Discontinued

Figure 2. The Philips Type PLA-107 One Cylinder Gas Liquifier
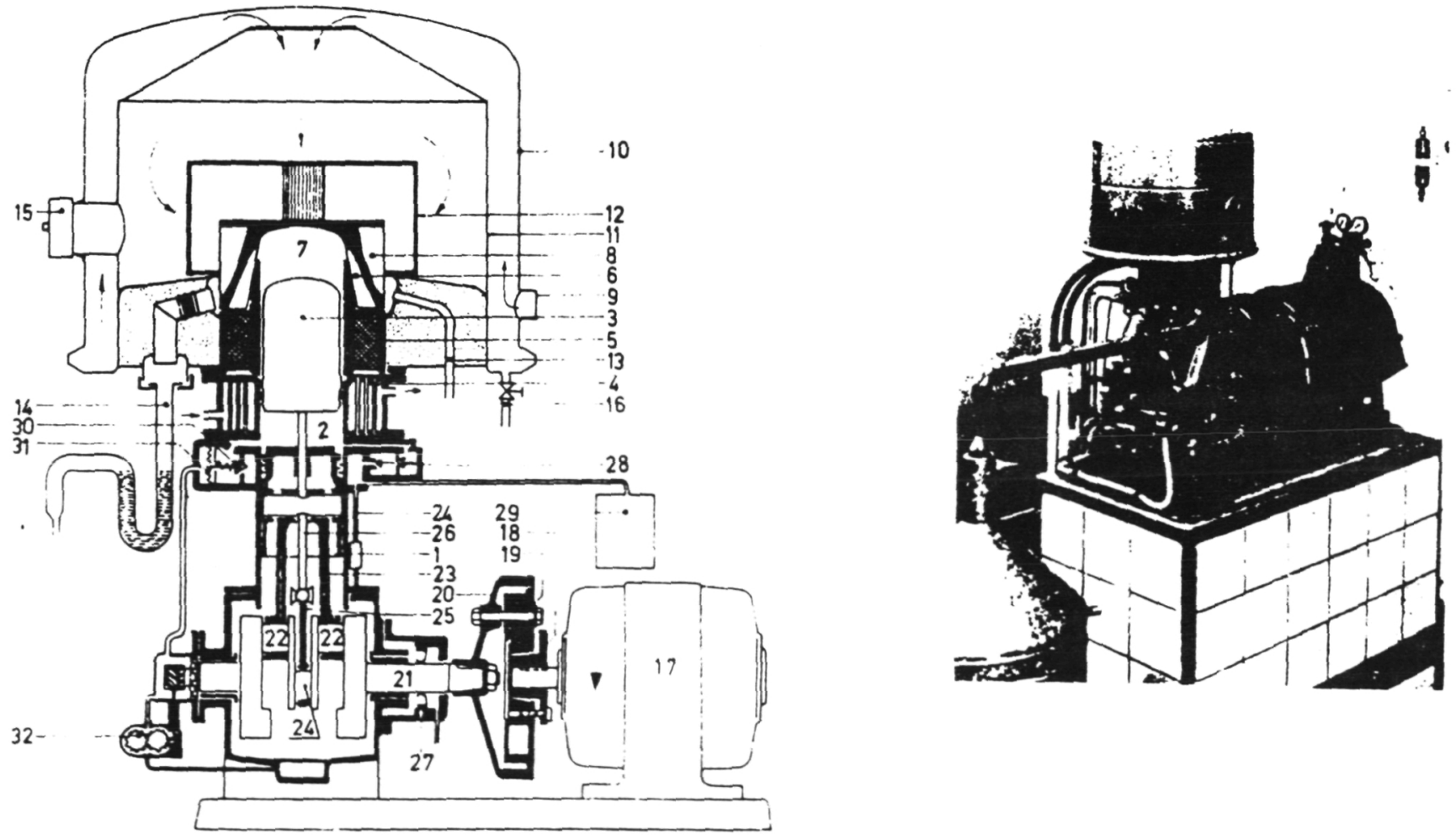

In the small cryocooler area, Stirling cycle coolers are taking over from Joule-Thompson coolers because they are easier for the operator to use. 
Military applications are the main market. Most of the coolers are mated to infrared sensors which makes any warm body visible to the operator. Figure 3 shows a section of a typical miniature cryocooler.

Figure 3. Small Integral Stirling Cooling Engine for Forward Looking Infrared Applications.
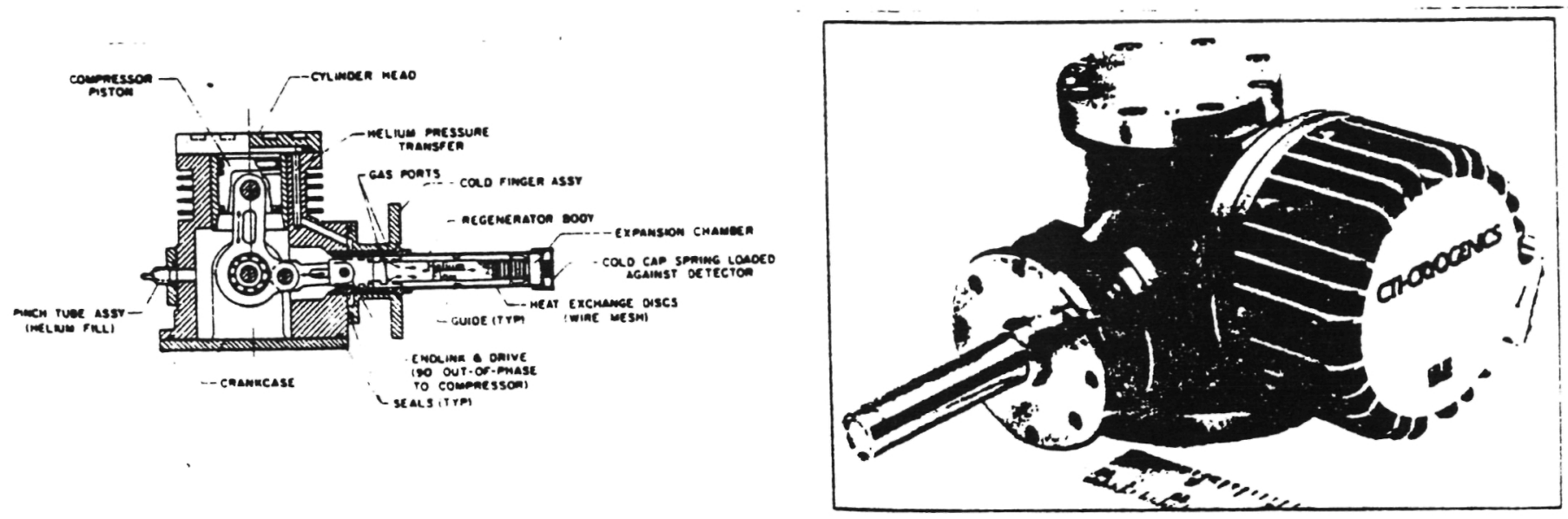

Many other types of cryocoolers have been built. Different milltary organizations have standard designs and are trying to broaden the base of cryocooler manufacturers. To date makers and the approximate number of miniature cryocoolers that have been manufactured is approximately as follows:

$\begin{array}{lr}\text { Philips-Magnavox } & 1000 \\ \text { Texas Instrument } & 5000 \\ \text { CTI Cryogenics } & 8000 \\ \text { Hughes Aircraft } & 2000\end{array}$

However in the future there will be many more. For instance, one U. S. Airforce air to ground missile program, the Maverick, will require 60,000 coolers.

Solar Theranl Power United Stirling of Sweden has stated that the first commercial application of Stirling engines will be for electric power generation using heat from a point focusing mirror. United stirling is participating in two projects. One is with the Slaisch Co. of Stuttgart in West Germany. The other is with the McDonnell Douglas Corp. of Long Beach, California.

The Slaisch Company will use the 4-275 engine and a $55 \mathrm{ft}$. diameter mirror to produce $60 \mathrm{~kW}$ of electricity. The power source is slated for installation in Saudi Arabia. The mirror is made by stretch forming a thin stainless steel sheet into a dish shape and holding it there against wind loading by applying a vacuum to the back side.

The McDonnell Douglas company will use the 4-95 engine and a roughly 36 ft. diameter mirror of their own design to produce a nominal $25 \mathrm{~kW}$ of electricity. Pigure 4 shows the mirror design, and Figure 5 shows the engine and receiver design. Flgure 6 shows one of the engines being serviced while two more-are in operation.-The system is being sold by McDonnell Douglas who will make the mirror. Volvo of Sweden will make the engine in quantity. When 
production is established, the system can be sold to utitities for less than $\$ 2000$ per installed $\mathrm{kW}(\mathrm{e})$ and $w i$ th a very low operation and maintenance expectation and of course no fuel cost. They feel that these costs, which do not take into account tax credits, are competitive with coal or nuclear plants.

Figure 4. McDonnell Douglas

Figure 5. United Stirling Solar Engine. Mirror Design.
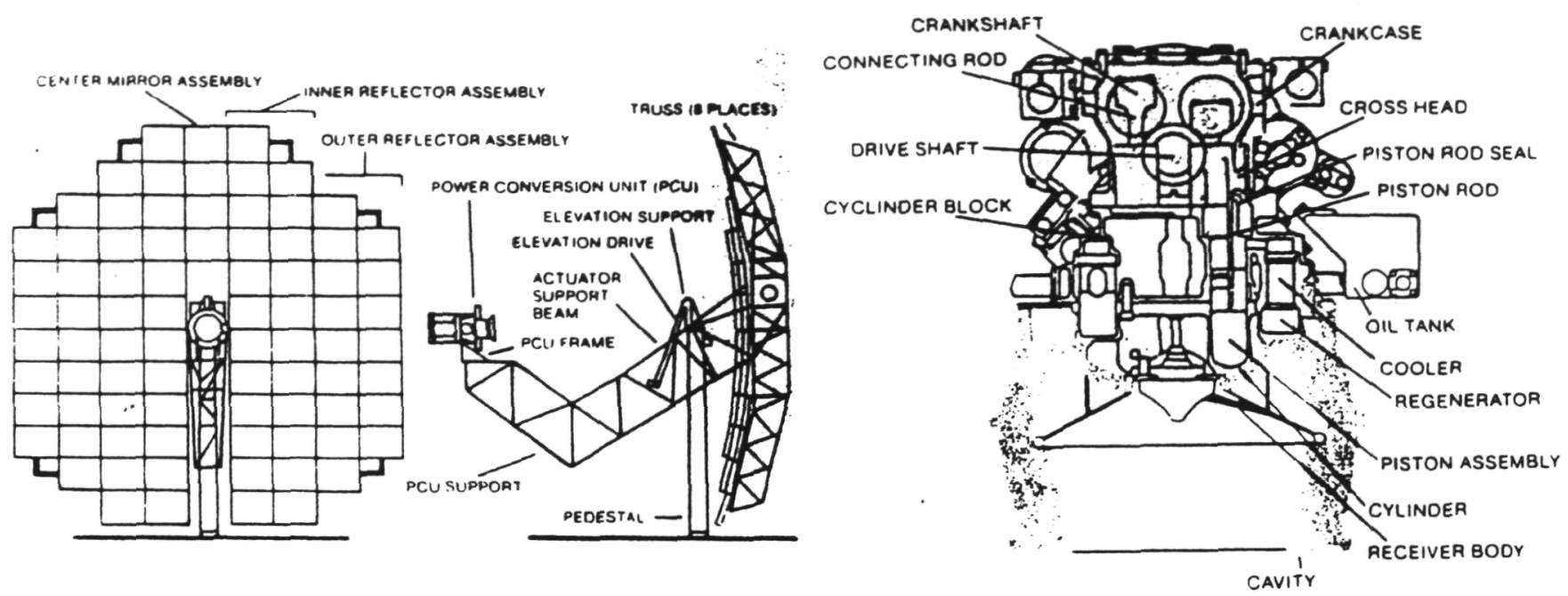

Figure 6. Artist Concept of Servicing Operation.

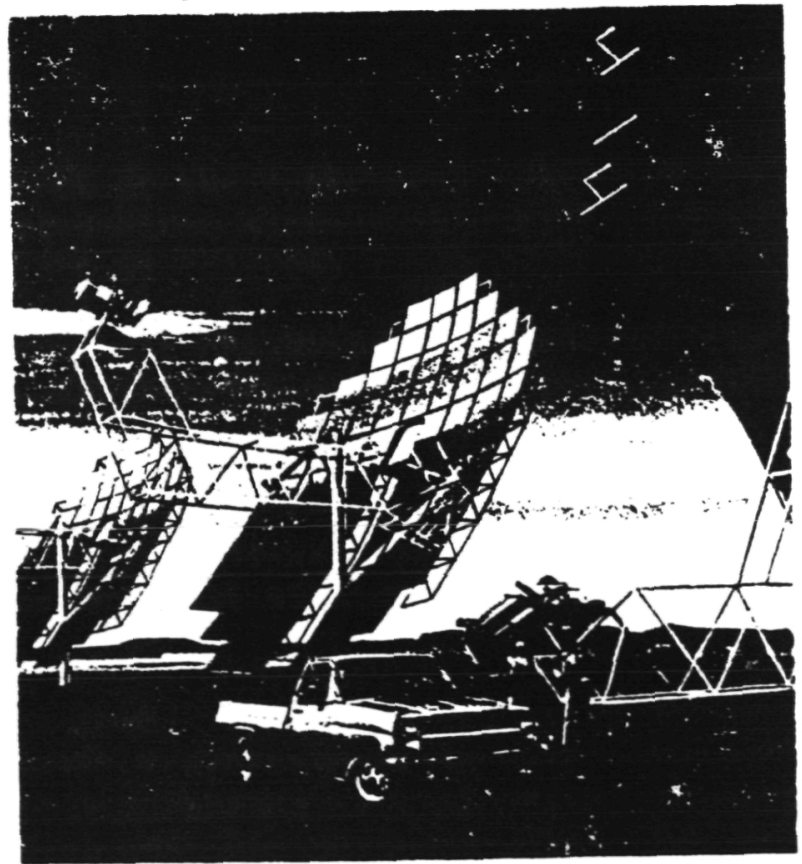

This commercial venture has benefited from a number of previous government programs. The engine started out to be the automobile engine. It was modified to operate in any position, to receive solar energy, and be controlled with this heat source. In a program administered by Jet Propulsion Laboratory, test hardware was designed and constructed for Rankine, Brayton, and Stirling cycle 
machines. The Stirling part was tacked on as an after thought, but turned out to be the only machine that was successfully tested during the life of the program. Then in a cooperative government-industry program the Vanguard solar thermal demonstrator was built at Paln Springs, California. This has been operated as a demonstrator to improve reliability and to make it into a machine that can be operated by utility personnel. The latest measured efficiencies for Vanguard are as follows:

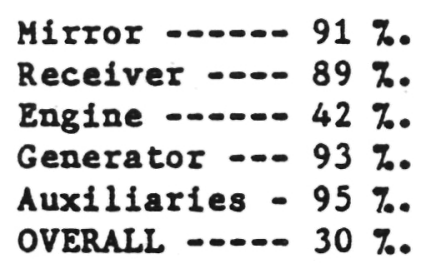

Currently 8 utilities have agreed to each buy one solar thermal power source similar to the Vanguard for testing in their own utility. They are scheduled to be delivered during 1985.

Sunpower has been working with Bomin Solar of West Germany to produce a 10 $\mathrm{kW}(\mathrm{e})$ solar thermal system. They are using a plastic mirror made from inflating the space between a clear and a silvered sheet of plastic held in a circular frame. The engine is a free-plston engine-generator. This engine was originally tested using a coal fire at Athens, Ohio. It is now being tested using concentrated solar heat in Germany.

Transportable Electric Generator A number of transportable electric generators have been built and are now in the demonstration stage. Makers are Sunpower, Mechanical Technology Inc., United Stirling, and Stirling Power Systems. These generators are designed to produce several kilowatts of electric power in a stand alone setting. They would have the advantage of being quieter than an internal combustion engine operating an electric generator and can use a number of fuels with little or no modification.

Sunpower The SPIKE II is a free-piston engine-generator which produces up to $1 \mathrm{kW(e)} \mathrm{at} \mathrm{up} \mathrm{to} 25 \%$ efficiency. This efficiency includes the engine and generator but not the burner. A propane or a natural gas burner has been designed for it. Figure 7 shows a cross section and a picture of the engine ready for testing. The machine is for sale for $\$ 52,875$ as a laboratory model with some instrumentation. It is for sale as a self contained model except for the fuel supply for $\$ 59,300$. One machine has been sold to Kawasaki of Japan for evaluation. Another will be used in a Battelle Northwest program to demonstrate a 22 \% efficient, isotope heated electric power source.

The SPIKE II is the successor to the RE-1000 engine built by Sunpower and extensively tested at NASA Lewis. The RE-1000 is a free-piston engine with a dash pot load. It has generated $1.5 \mathrm{~kW}$ of mechanical power at $32 \%$ efficiency. This engine is electrically heated and powers no auxillaries. The SPIKE II is designed to be cheaper to build by using low pressure helium as a working fluid (10 bar). Therefore, the manufacturing tolerance on the parts can be greatly relaxed. This type of machine has the potential for having a very long life. However, this has not as yet been demonstrated.

Sunpower is also supplying a $3 \mathrm{~kW}(e)$ generator to Ft. Belvoir, U. S. Army under a fixed price purchase order. 

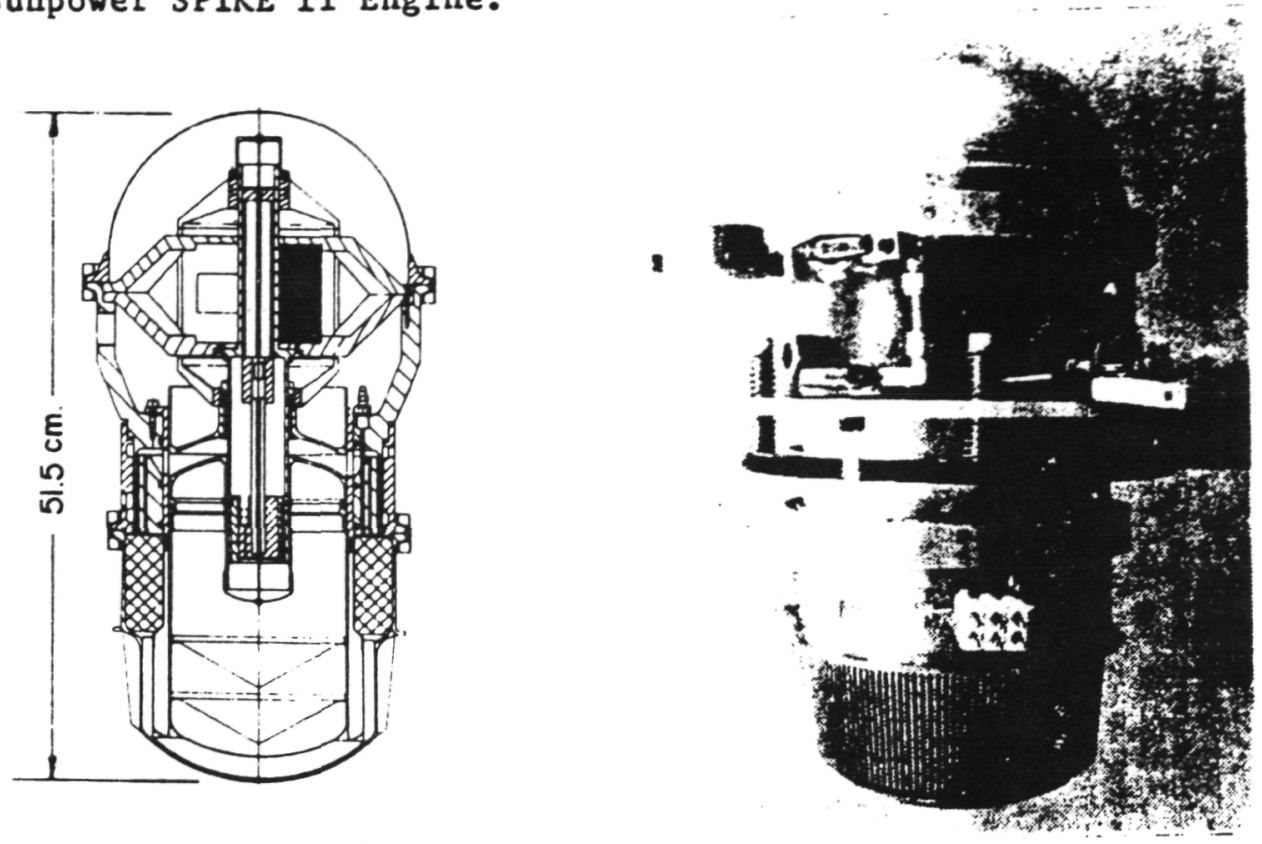

Mechanical Technology Inc. (MTI) In the form of a research contract MERADCOM at Ft. Belvoir, Virginia has engaged MTI to supply two self-contained electric power sources rated at $3 \mathrm{~kW}(e)$. These are based upon previous $3 \mathrm{~kW}(\mathrm{e})$ free-piston engine generators that have been under development at MTI for several years. These engines have been assembled with their control panel and all the auxiliaries to make a self contained unit. It is designed to operate on diesel fuel. The idea is to make a machine that would be inherently more quiet than diesel machines usually are and have at least as good an efficiency. Figure 8 shows a cross section of the engine and generator part of this power source.

The U. S. Army is also considering the MTI Mod 2 engine developed under the automotive program as an engine for a low noise, multifueled transportable power source.

United Stirling $A B$ (USAB) Figure 9 shows their 4-95 Stirling engine electricity generating set. It can use gasoline, diesel fuel, kerosene, methanol, natural gas or sewer gas. It is quiet and non-polluting in operation. It is rated at $28 \mathrm{~kW}(\mathrm{e})$ and at this point consumes 310 grams of gasoline per $\mathrm{kWh}$. The power source is a prototype to generate interest.

Stirling Power Systems of Ann Arbor, Michigan (now a subsidiary of United Stirling of Sweden.) has a well-engineered power source in the 10 to $20 \mathrm{hp}$. range that operates on liquid fuel and produces electricity. At one time they had their units in eight Winnebago motor homes. Employees took these on family vacations with excellent results. They were used for lighting, air conditioning hot water and cooking. The waste heat was used for space heating. This development never went into commercial production because the necessary large investment to bufld the factory to bring the cost of the power source within a reasonable range could not be secured as yet. Similar generator sets have been tested by the Gas Research Institute and MERADCOM at Ft. Belvoir. 


\section{ORICINAL PAGE IS \\ OF, POOR QUALTTY}

Figure 8 The MTI Three Kilowatt Engine-Generator

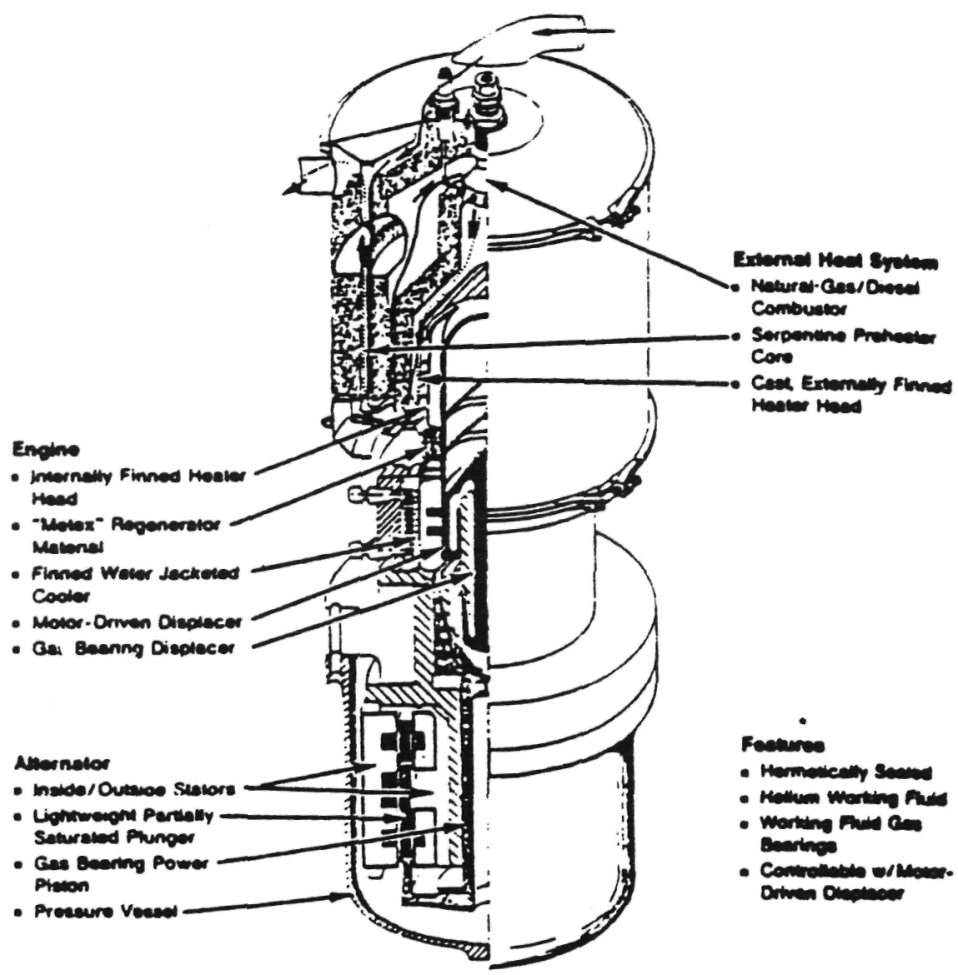

Figure 9. The United Stirling 4-95 Stirling Engine Electricity Generating Set

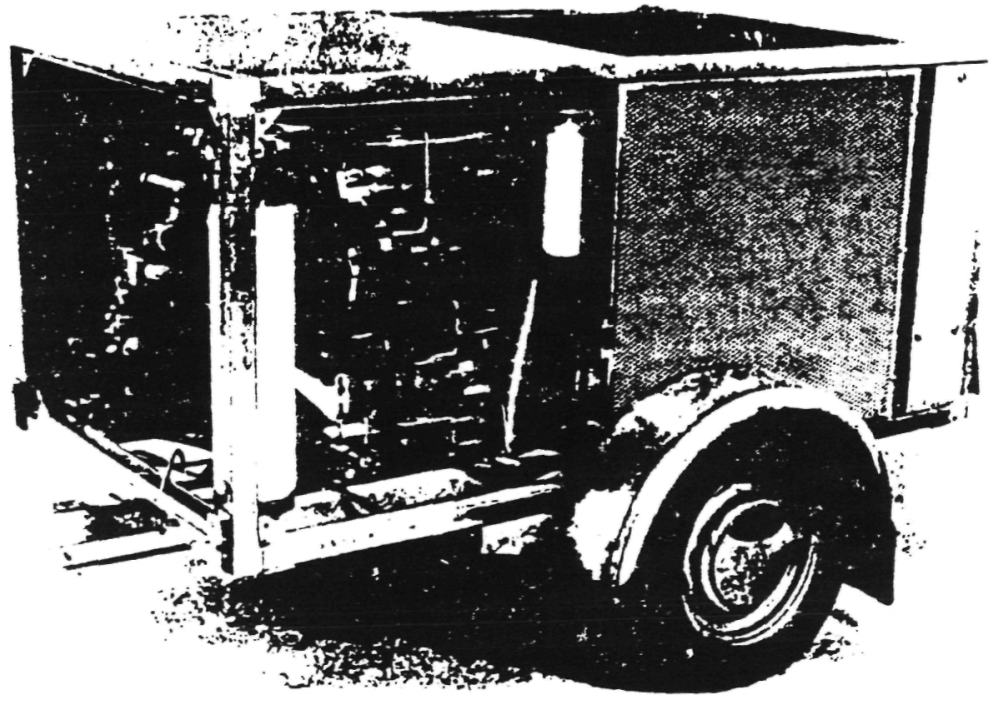




\section{ORIGINAL PAGE IS \\ OF POOR QUALITY}

Four of these machines are regularly used by the City of Malmo, Sweden. They are the power source of choice where conventional machines would make too much noise and disturb the residents.

The U. S. Army Research and Development Center has awarded a $\$ 3$ million contract to Tiernay Turbines for ten 5-kW Stirling engine driven generator sets. Stirling Power Systems will supply the V-160 engine. Figure 10 shows a cross section of this engine. The Army points out that their existing smaller generator sets, while rugged and of good quality, are old, and designed to operate on only one fuel. They are easily detected by the enemy because of the noise and heat they generate, and often do not use the same type fuel as the system"s transport vehicles. A Stirling engine generator set is quieter than the conventional generator sets, has longer potential life and can use a wide variety of fuels. The 10 militarized stirling engine driven generator sets are to be delivered in 1985. These sets will be subjected to extensive testing by the Army to determine the suitability of the Stirling engine for military use. If proven suitable, the Stirling engine generator set will then be considered as a power source for communications equipment, command posts, visual and infrared illumination devices, and other support equipment where its reliability, non-detectability, and multifuel capabilities are essential to mission success.

Figure 10 Cross Section of the Stirling Power Systems V160 Engine.
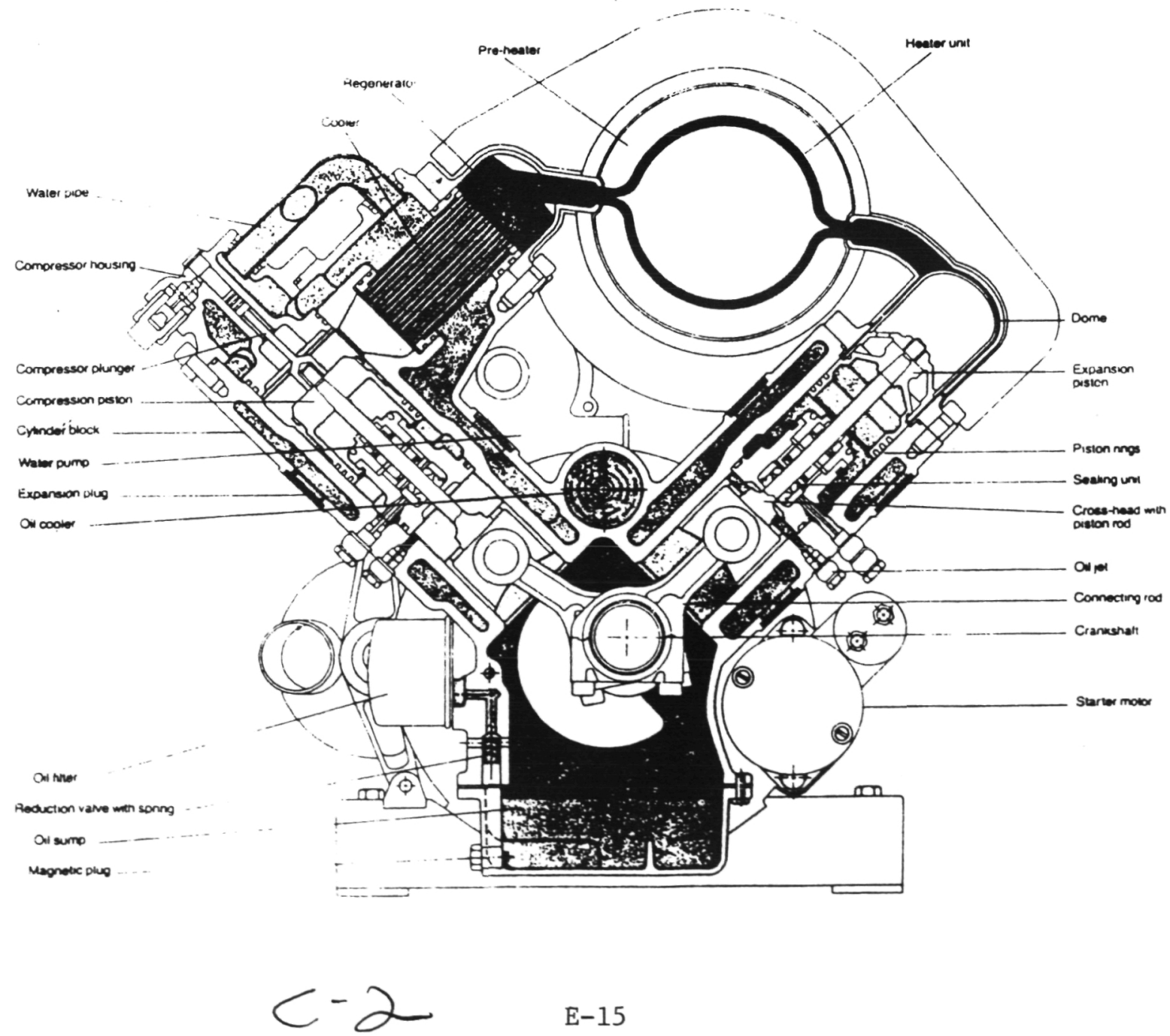
The Stirling engine group at the University of Washington's Jolnt Center for Graduate study are working on a 200 Watt Stirling engine power source for the U. S. Army Signal Corps. It involves the technology that this group has been applying to the artificial heart application.

Heat Operated Heat Punps Stirling cycle machines have much to contribute in the area of heat operated heat pumps. There are a great variety of ways that the stirling cycle can be used to more efficiently heat and cool buildings. A number of firms see application here within a few years.

B. V. Stirling Motors Europe has been established in the Netherlands with the aid of Fritz Philips, retired head of the N. V. Philips company and long time supporter of the Stirling engine. This company will make the engine designed by Roelf Meijer, president of Stirling Thermal Motors Inc. of Ann Arbor, Michigan. They have announced plans to build 200 of their $40 \mathrm{~kW}$ engines in 1986 and increase to 10,000 per year in 1990. This marks the first time that quantity productions plans for a stirling engine have actually been announced.

Pigure 11 shows a section of this engine. The heater tubes are heated by a heat pipe so that any source of heat may be used without disturbing the engine design. The engine uses a swashplate driving four double-acting pistons as in a previous Philips engine. However this swash plate can change its angle during operation to control engine power. By using a rotary seal on the output shaft, they pressurize the crank case to $11 \mathrm{MPa}$ (1600 psi) and eliminate the need for really tight shaft seals on the pistons.

Figure 11 Cross Section of the Stirling Thermal Motors 40 Kilowatt Engine

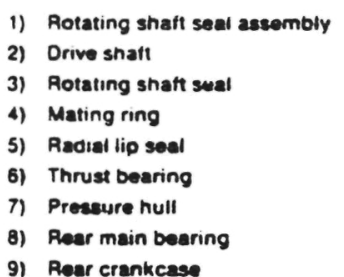

2) Drive snatt

4) Mating ring

5) Radial lip soal

9) Roar crankcase

10) Rotary actuator
11) Main snan
12) Bovet gear
13) Swashplate
14) Front main bearing
15) Oil pump module
16) Front crankcaes
17) Cooler
18) Regeneretor

19) Heater

20) Hot connecting duct

21) Piston aseembly

22) Oylinder/regenerator housing

23) Hydraulic service aseombly

24) Power control valve

25) Oll scraper/capseal assembly

20) Crosensed

27) Accumulator

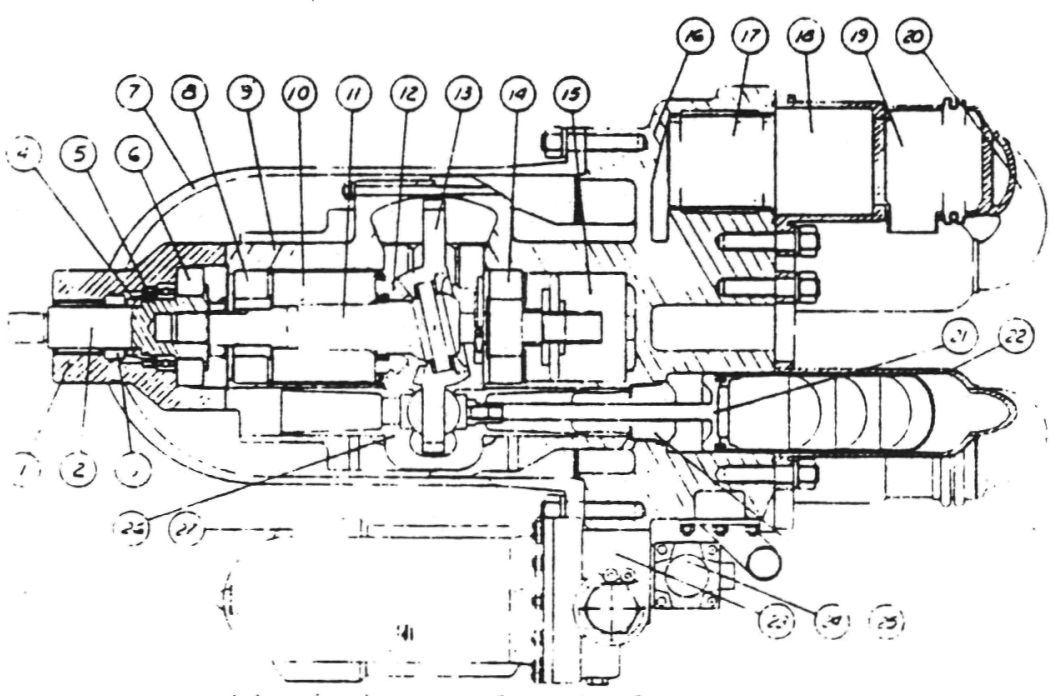


Dr. Meijer identifies that the first application will be for heat operated heat pumps for the green houses in the Netherlands. They can no longer afford to heat with gas. They need the $140 \%$ efficiency that a heat operated heat pump can offer. This engine will be mechanically coupled to a conventional Rankine cycle heat pump. The output of the heat pump plus the reject heat from the engine will be combined as the useful product.

Mechanical Technology Inc. (MTI) has been adapting their $3 \mathrm{~kW}$ free-piston engine to be a freon pump for a household heat pump. This work has been sponsored by the Department of Energy, the Gas Research Institute, Lennox Industries, Consolidated Natural Gas, and MTI. Performance goals are given in Table 2. The engine is similar to that shown in Figure 8 . Figure 12 shows how the generator is replaced with a freon compressor. A diaphragm coupling and hydraulic transmission are used to transfer power from the engine to the compressor while maintaining a positive seal between the two.

Table 2 Performance Goals for the MTI Free Piston Stirling Engine Heat Pump

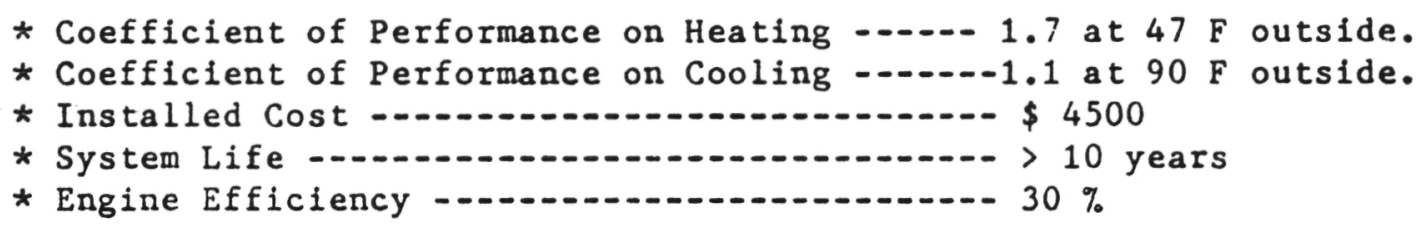

Figure 12. Principle Engine/Compressor Characteristics

\section{CNG/MTI CONFIGURATION}

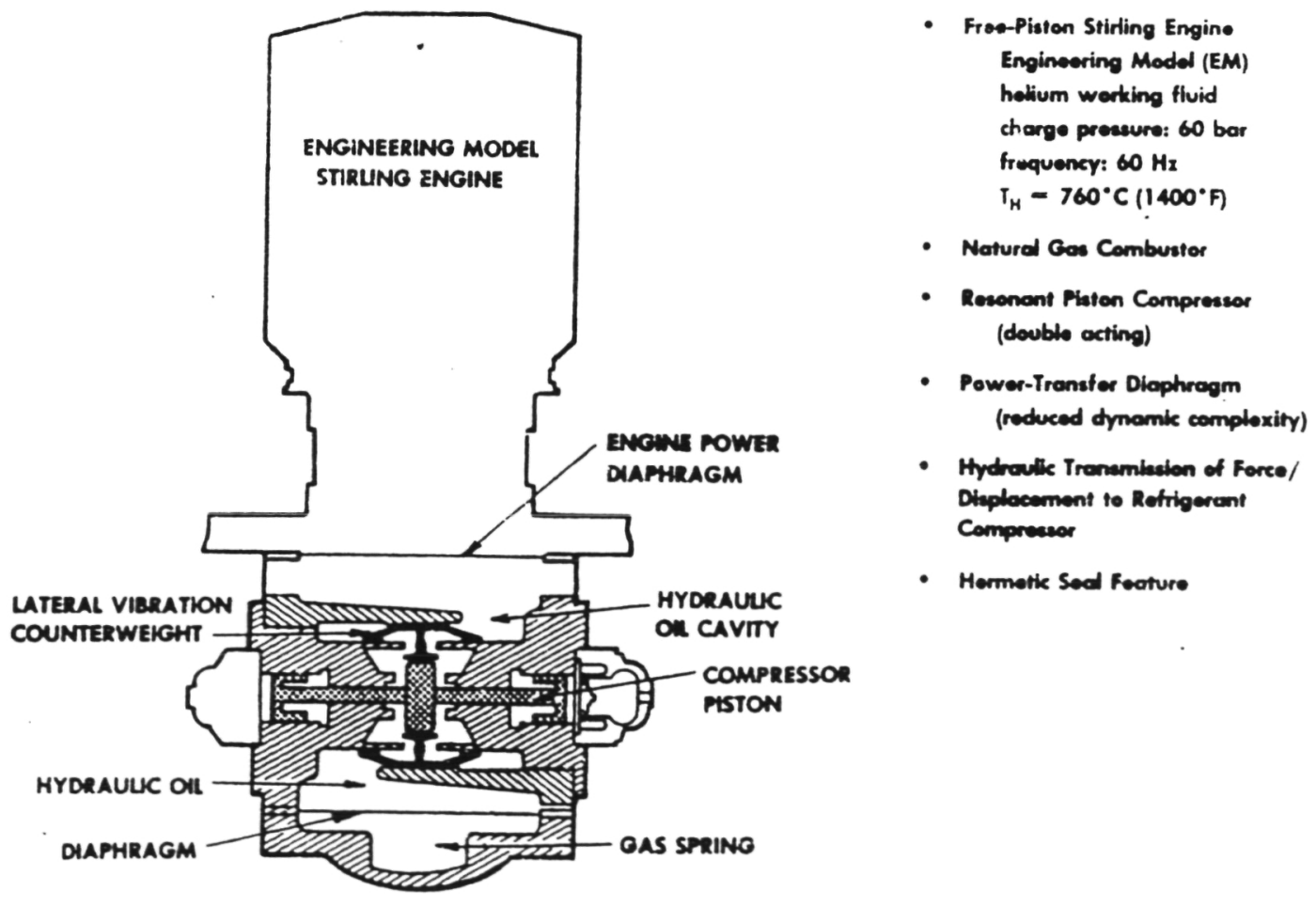


To date, the engine has been tested at its rated power and at a mechanical effictency of $32 \%$. That is, $32 \%$ of the energy derived from the lower heating value of the natural gas burned by the engine is applied to the diaphragm leading to the hydraulic power transmission. The compressor has demonstrated an operating efficiency of $60 \%$. That is $60 \%$ of the power applied to the above mentioned diaphragm results in power applied to compressing freon. It is now becoming customary to relate efficiency to the higher heating value of the fuel. For methane the ratio of the lower heating value to the higher heating value is 0.90 . Therefore, the overall efficiency of this heat operated compressor is $0.9 \times 0.6 \times 32 \%=17.3 \%$. Assuming that the cost projection from Table 2 can be realized, and assuming the current measured performance, then a six-year payback period can be realized for most parts of the country. The development potential is to eventually achieve a three-year payback period. Full development and field testing is scheduled to be complete in 1989.

Sunpower pioneered a concept in which a hermetically sealed free-piston Stirling engine powered a freon compressor. This program was sponsored by the Gas Research Institute and the Department of Energy and was taken over by General Electric, Valley Forge to make it into a commercial product. General electric is now studying the use of Stirling cycle heat pumps in chemical processes.

Sunpower Inc. has built several test engines in which a free-piston Stirling engine operates a free-piston Stirling heat pump. In this type of machine there are two displacers and one power piston. The two machines use a common helium working fluid in a sealed container. Figure 13 shows the principle of this concept. Using this principle a natural gas liquifier had been built and demonstrated. Also a residential heat pump was built and tested. It demonstrated that it would work and produce 1.5 units of heat at $47 \mathrm{C}$ for every unit of heat produced by burning natural gas assuming the lower heating value. Finally a duplex refrigerator demonstrator has been built (See Figure 14.). This has demonstrated the dual use capacity of this machine being both a refrigerator and a water heater. Sunpower feels that this unit shows promise as the basis of a household appliance.

The Toshiba Corporation of Japan is developing a heat operated heat pump product. They are using a two-piston Stirling engine patterned after the V-160 of Stirling Power Systems. However, they are using a combustion chamber filled with aluminum oxide pellets. The heater and cooler use relatively few tubes. Each tube is intermally finned and packed so that all the flow goes thru the fins. The product development is in the early stages. They are aiming for a heating $C O P$ of 1.4. They are aiming for a $3 \mathrm{~kW}$ engine with an efficiency of 32 \% running on natural gas. They would like it to be quiet, $45 \mathrm{~dB}(\mathrm{~A})$.

Onattended Electric Generator In this application the emphasis is on long term operation without maintenance. The idea would be to require only yearly visits to supply propane fuel or use nearly permanent radioisotope fuel. The HoMach Company of Swindon, United Kingdom is building upon work done by workers at the Atomic Energy Research Establishment at Harwell to build a $120 W(e)$ engine-generator fueled by propane. It should have an efficiency of $17 \%$ from heat input to electric power output. This machine is patterned after a lower power, isotope heated machine that is still in continuous operation after almost 9 years. The strontium-90 heat source has decayed but the performance of the engine generator has not. The engine has no rubbing contacts. It uses a diaphragm as the seal and a leaf springs as bearings. They expect that the 


\section{ORIGINAL PAGE IS \\ OF POOR QUALITY}

Figure 13. Principle of the Duplex Stirling Machine
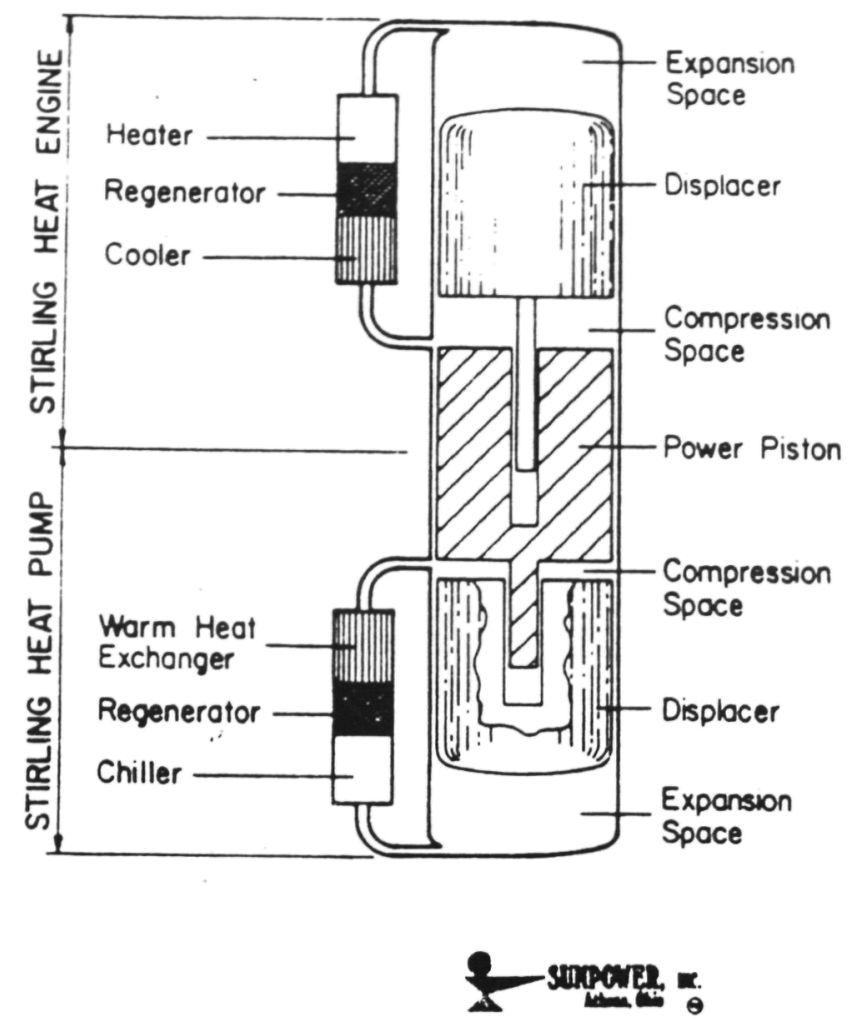

Figure 15. Principle of the Thermomechanical Generator

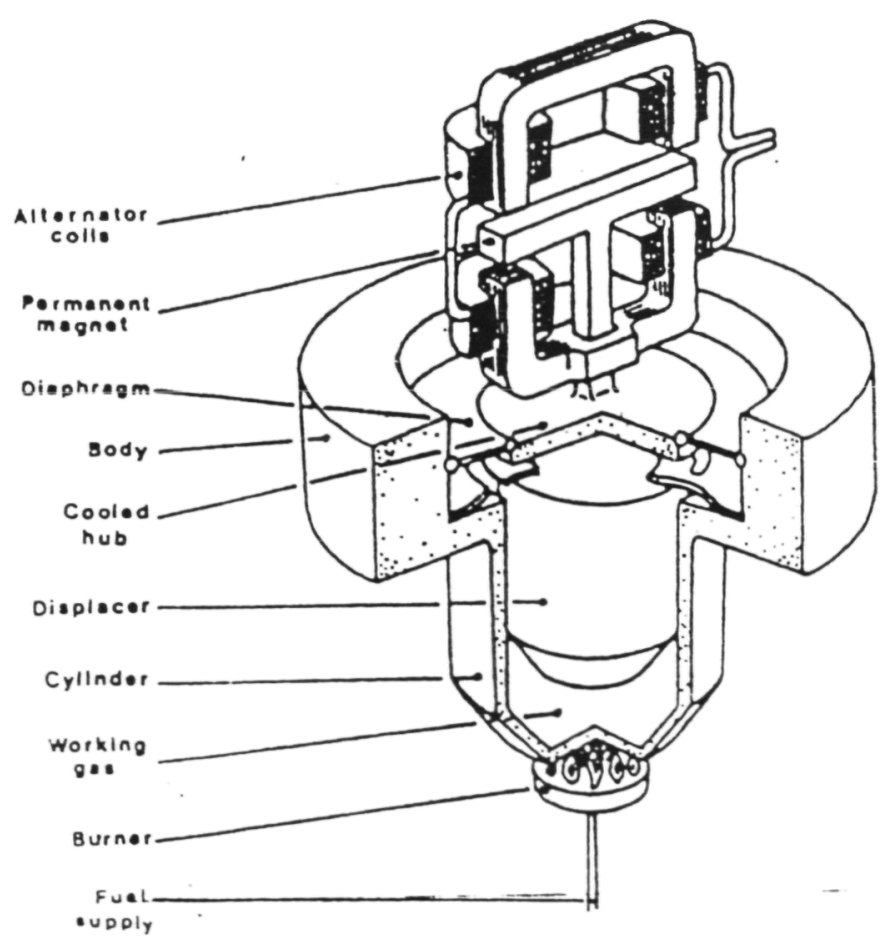

Figure 14. The Sunpower Duplex Stirling Demonstrator

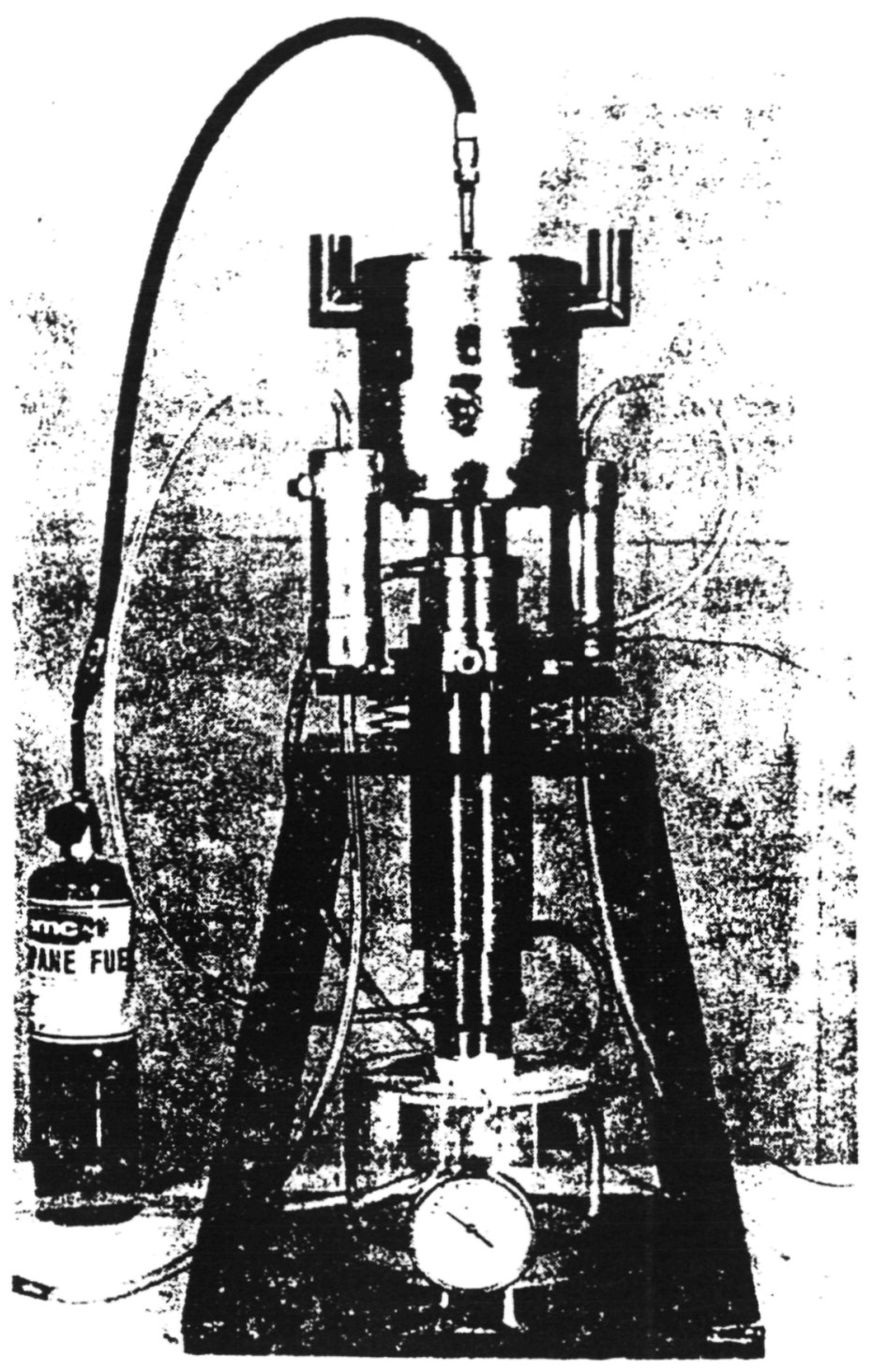


engine generator can be sold for less money than a thermoelectric generator. The task of resupply would be much cheaper since it uses only one third the fuel. It is also expected to last much longer since there is expected to be no degradation. Prototype machines have been used in data buoys and at unmanned lighthouses. The initial model, a propane fueled 120 watt electric power source is now being offered for 15,000 pounds (U.K.). Three so far have been sold. One is installed and is operating on the top of a $3000 \mathrm{ft}$. mountain in Northern Sweden. Two have been purchased by the Canadian Department of Transport. The principle of this machine is shown in Figure 15.

\section{IMPORTANT BUT LONG RANGE DEVELOPMENT PROGRAMS}

Automobile or Truck Power The most common question I have received is "Can it run an automobile?" For test purposes the Stirling engine has run many vehicles. Philips powered a bus. United Stirling powered a Tanus automobile and a light truck. MTI powered three automobiles. Last of all Toyota has now powered a Corrola with Aisin-Seiki's spash plate Stirling engine. The Toyota is said to run well except for slow acceleration. Nothing fires the imagination as having the engine in an automobile eventhough engineers rate the auto as one of the most difficult applications.

The United States Congress determined that the auto industry needed help in finding both a non-poluting and efficient alternative to the internal combustion engine. A very large program was therefore funded thru the Department of Energy to demonstrate a more efficient and non-poluting automobile engine based upon the Stirling engine. A similar program is being financed based upon the gas turbine. This stirling engine program is being administered by NASALewis which also does some in-house research. The prime contractor on this program is Mechanical Technology Inc., of Latham NY. Major subcontractors are United Stirling of sweden for the engine and AM General for integration with the vehicle. The program has been going since March 1978. It has as its goal the demonstration of a suitable engine system that would be quiet, non-poluting and have $30 \%$ better gas mileage with the same drivability as a spark ignition vehicle. It also should have reasonably close to the same cost of manufacture.

The program started with an existing engine, the P-40, from United Stirling and by mostly evolutionary steps proceeded to improve it and adapt it to an automobile environment. There were to be two hardware engines the Mod I and the Mod II, and a paper engine, the Reference Engine System Design (RESD) to serve as a focal point for all the component, subsystem, and system development within the program. The RESD is the best engine that could be built. Because of funding revision the Mod II was never built, but the Mod I was revised. Construction of the Mod II has just recently been authorfzed by Congress. In all, seven Mod I engines are being used in the program. Figure 16 shows how the RESD has evolved during the program. The emphasis has not only been on increasing performance but on reducing cost. Cost estimates have been made by the Pioneer Engineering Company who regularly estimate costs for the automobile industry. Table 3 shows the calculated vehicle characteristics using the RESD engine. Note that the mileage, the acceleration, and the cost are all very attractive. Table 4 shows the calculated RESD engine performance. 
Figure 16 Evolution of the RESD Engine

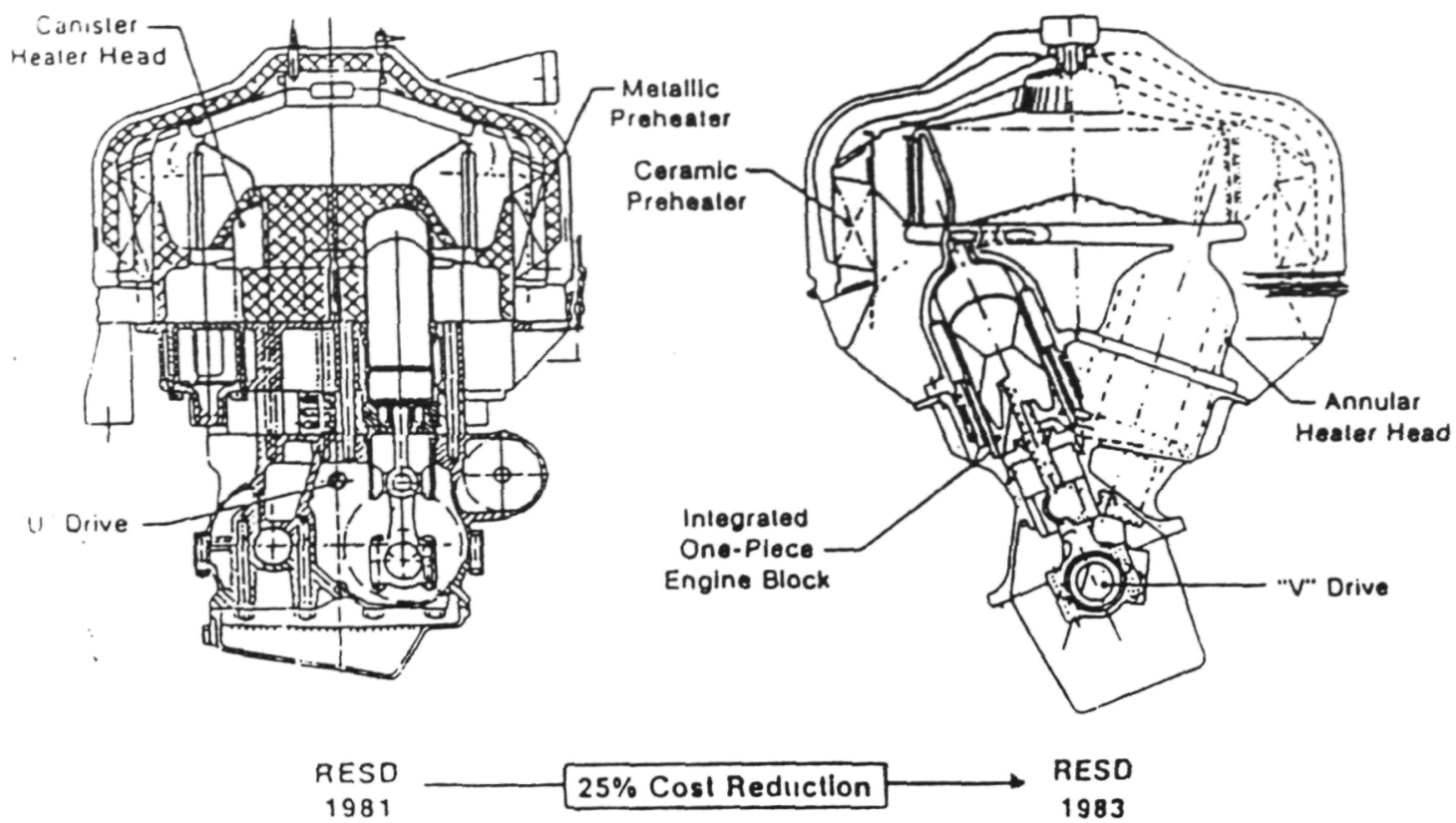

Table 3 Calculated Vehicle Characteristics with the RESD Engine

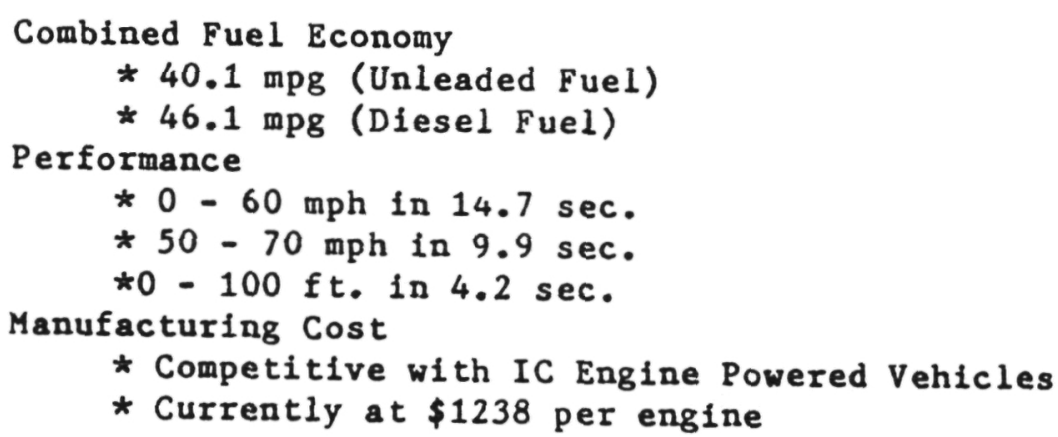

Table 4 RESD Engine Performance Summary

$\begin{array}{lcccc}\begin{array}{l}\text { Operating } \\ \text { Point }\end{array} & \begin{array}{l}\text { Power } \\ (\mathrm{kW})\end{array} & \begin{array}{c}\text { Efficiency } \\ (\%)\end{array} & \begin{array}{c}\text { Speed } \\ \text { (rpm) }\end{array} & \begin{array}{l}\text { Working Gas } \\ \text { Pressure } \\ \text { (MPa) }\end{array} \\ \begin{array}{l}\text { Maximum } \\ \text { Power }\end{array} & 60.0 & 34.6 & 4000 & 15 \\ \begin{array}{l}\text { Maximum } \\ \text { Efficiency }\end{array} & 25.5 & 42.2 & 1350 & 15 \\ \begin{array}{l}\text { Part } \\ \text { Power }\end{array} & 12.0 & 37.3 & 2000 & 5\end{array}$

To clarify Table 3, MTI reports that the latest cost analysis by Pioneer Engineering place the RESD engine slightly less expensive to manufacture than the diesel. 
As part of an industry test and evaluation program MTI has prepared and delivered to General Motors an upgraded Mod I engine in an AMC Spirit vehicle. General Motors has now flnished a very rugged test of this vehicle. This is very good for an experimental vehicle. An engine will be delivered to Deere and Company for evaluation in a test cell. These engines are numbers 8 and 9 in the Mod I series.

United Stirling of Sweden has prepared their 4-275 engine for use in trucks in an underground iron mine in northern Sweden. This engine now has a measured maximum efficiency, with all auxillaries powered, of $38.67 \%$ at a power of $51.5 \mathrm{kw}$. It has a maximum power of $91.76 \mathrm{kw}$ at $2600 \mathrm{rpm}$ and an efficiency of 34 \%. The truck engine project is stalled because of the down turn in the steel industry worldwide, but the engine is being used in other applications.

Space Power Stirling engines have gained new-found legitimacy by being seriously considered for space power both solar and nuclear powered. The credit for bringing this relatively new possibility to the attention of the system designers goes to NASA-Lewis with an assist from MTI and Sunpower. The requirements are lightweight, high efficiency and very long life. In addition there is a limit to heat source temperature because of current nuclear reactor technology. Also to reduce the overall weight of the system, the radiator temperature should be high.

Thru the co-operation of a number of government agencies the SP-100 program is underway to develop a $100 \mathrm{~kW}(\mathrm{e})$ power source using a nuclear reactor heat source for military and civilian applications. All possible technologies are being considered for this requirement. The problems with the Stirling engines is that the free-piston engine-generators had been successfully tested only up to $3 \mathrm{~kW}(\mathrm{e})$. The plan was to use four pairs of engines back to back for dynamic balancing. Each pair would produce $25 \mathrm{~kW}(e)$. Therefore there is a scale up problem from $3 \mathrm{~kW}$ to $12.5 \mathrm{~kW}$. This should not be considered serious in the light of the $10 \mathrm{~kW}(e)$ engine built by Sunpower. Another problem is life time demonstration. Only very small engines have lasted or have even been tested for long times without maintenance. As part of the space/heat pump program a 1000 hour test has been undertaken. On the SP-100 program this is now being extended to 10,000 hours at MTI with the same engine. Finally, there is the problem that stirling engines had never been built for the low temperature ratios that system analysts had calculated would be optimum for the space electric power application. An experimental and an analytical program have now been instituted to close this gap.

The experimental program has been instituted at MTI. Figure 17 shows a section of one cylinder of this space power demonstrator engine. The two halves are foined with a common expansion space to achieve dynamic balance. The design temperature ratio is 2 . However in order to reduce risk in building the first demonstrator, the heat source temperature was reduced to $650 \mathrm{~K}$. Also the temperature ratio of 2 is a compromise between the usual temperature ratio of 3 used in Stirling engines and a temperature ratio of 1.65 which may be the lower range. The specific weight of the engine generator is to be $8 \mathrm{~kg} / \mathrm{kH}(\mathrm{e})$ initially with a goal of $6 \mathrm{~kg} / \mathrm{kW}(e)$. The overall system efficiency is expected to be $25 \%$. 


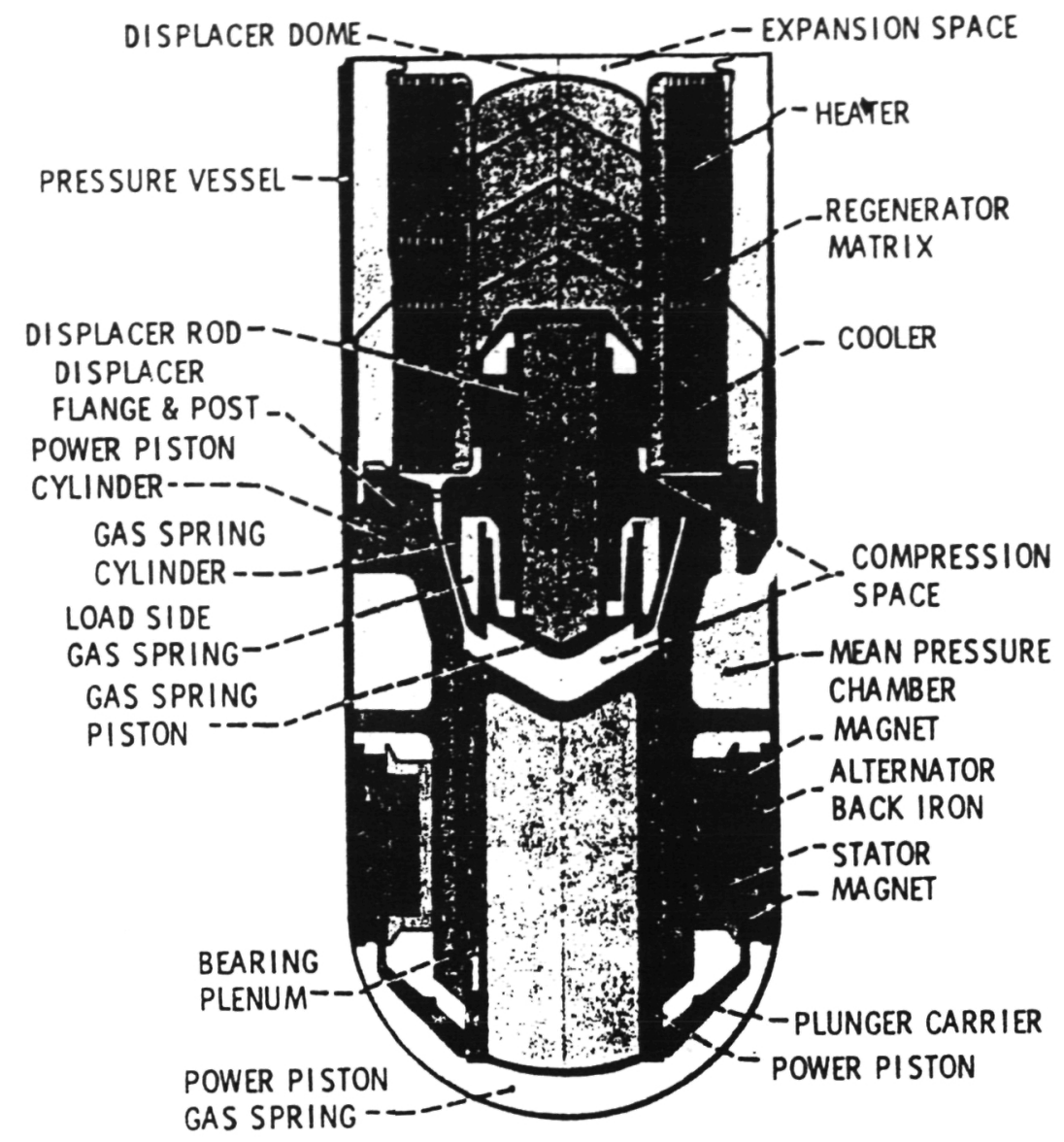

A chiefly analytical program is underway at Sunpower. Briefly, this is for an independent design for a long life, high efficiency engine generator with a heat source temperature of $875 \mathrm{~K}$ and a heat sink temperature of $530 \mathrm{~K}$ (Temperature ratio of 1.65.$)$. They plan to use hydrodynamic gas bearings which they will demonstrate experimentally. The displacer and the power piston will be spun using vanes attached to the displacer and the power piston and the natural motion of the gas back and forth inside the engine. They plan to try for a specific weight less than $6 \mathrm{~kg} / \mathrm{kW}(\mathrm{e})$.

Also, part of the SP-100 program is a contract awarded thru the SBIR program to Energy Research and Generation (ERG). The ERG contract is for building and testing two different types of lightweight linear alternators. However, ERG's alternator combined with their engine design is claimed by ERG to "have a potential specific weight of $1 \mathrm{~kg} / \mathrm{kW}(e)$ and an overall bus-bar efficiency of $40 \%$ using $1500 \mathrm{~K}$ heat input by 1 ithium heat pipes and $750 \mathrm{~K}$ heat rejection by potasium heat pipe radiators."

Thru JPL a systems study contract was awarded to Rockwell International, to do an independent system design and to consider a number of innovative alternatives. The engine subcontractor is MTI and the consultant on engines and Innovative systems'is JCGS. 
Submarine Power In a joint venture the Comex Industries of Marseilles, France, United Stirling $A B$ of Malmo, Sweden have adapted their well-proven 4-95 engine to underwater operations. This machine produces $30 \mathrm{~kW}$ of electricity plus $65 \mathrm{~kW}$ of hot water at $50 \mathrm{C}$ for divers and compartment heating. Submarines using the stirling engine are said to be five times better than the conventional submarine with batteries and an air breathing diesel engine. The combustion system operates at a pressure existing at 300 meters below the surface. The fuel is either methanol or diesel fuel. The oxidizer is pure oxygen. Using ejector tubes the pure oxygen aspirates four times it volume of exhaust gas that has already passed thru the heater tubes of the engine. Therefore the fuel burns in a synthetic air with the usual $20 \%$ oxygen. An oxygen preheater is not considered necessary since only $20 \%$ of the exhaust gases passing thru the engine heater would pass thru the preheater. Since the exhaust is entirely water vapor and carbon dioxide, cooling it and adding some sea water should produce a bubble-free effluent. Figure 18 shows a section of this engine.

Figure 18 The United Stirling

4-95 Underwater Engine
Figure 19. The United Stirling 4-275 Underwater Engine
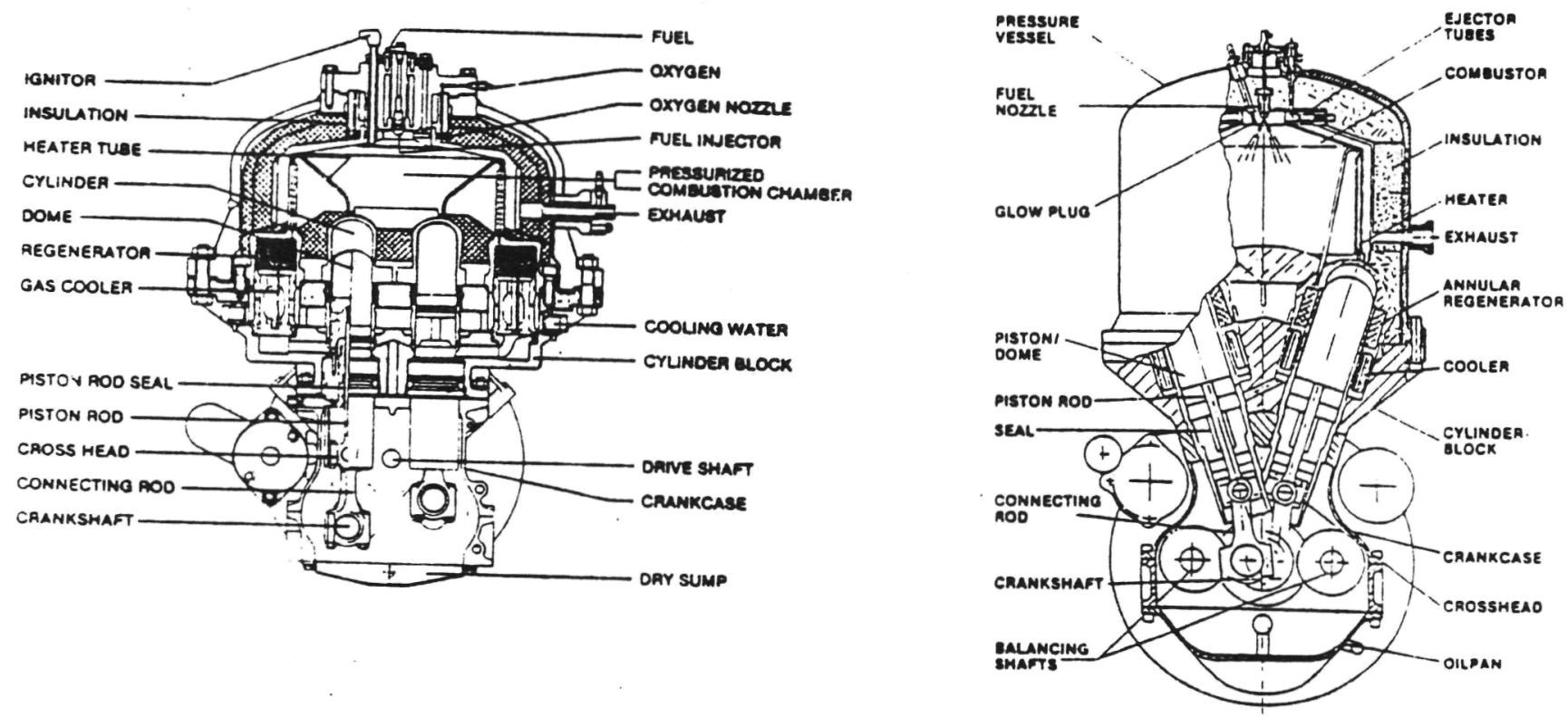

Based upon the above technology, United Stirling is supplying to the Royal Swedish Navy an energy supply module in the 65 to $100 \mathrm{~kW}$ range based upon the 4-275 Stirling engine integrated with a LOX system. Figure 19 shows the engine concept. Note that they have gone back to using a single crank and have annular regenerators to decrease the heat leak.

An entirely different underwater engine is being built and tested by Societe ECA of Meudon, France using a heat source developed by the Nuclear Research Center in Grenoble, France. Figure 20 shows the concept. A vessel contairing molten lithium-magnesium fluoride eutectic is the heat source. The heat source is charged by melting the salt using electromagnetic induction. Heat pipes conduct the heat from the molten salt to the Stirling engine. Their system studies show that they can get $20 \mathrm{Wh}(\mathrm{m}) / \mathrm{kg}$ with a conventional lead acid 
battery and an electric motor. They expect to realize $100 \mathrm{Wh}(\mathrm{m}) / \mathrm{kg}$ with the thermal storage-Stirling engine system.

Figure 20 ECA Submarine Engine System

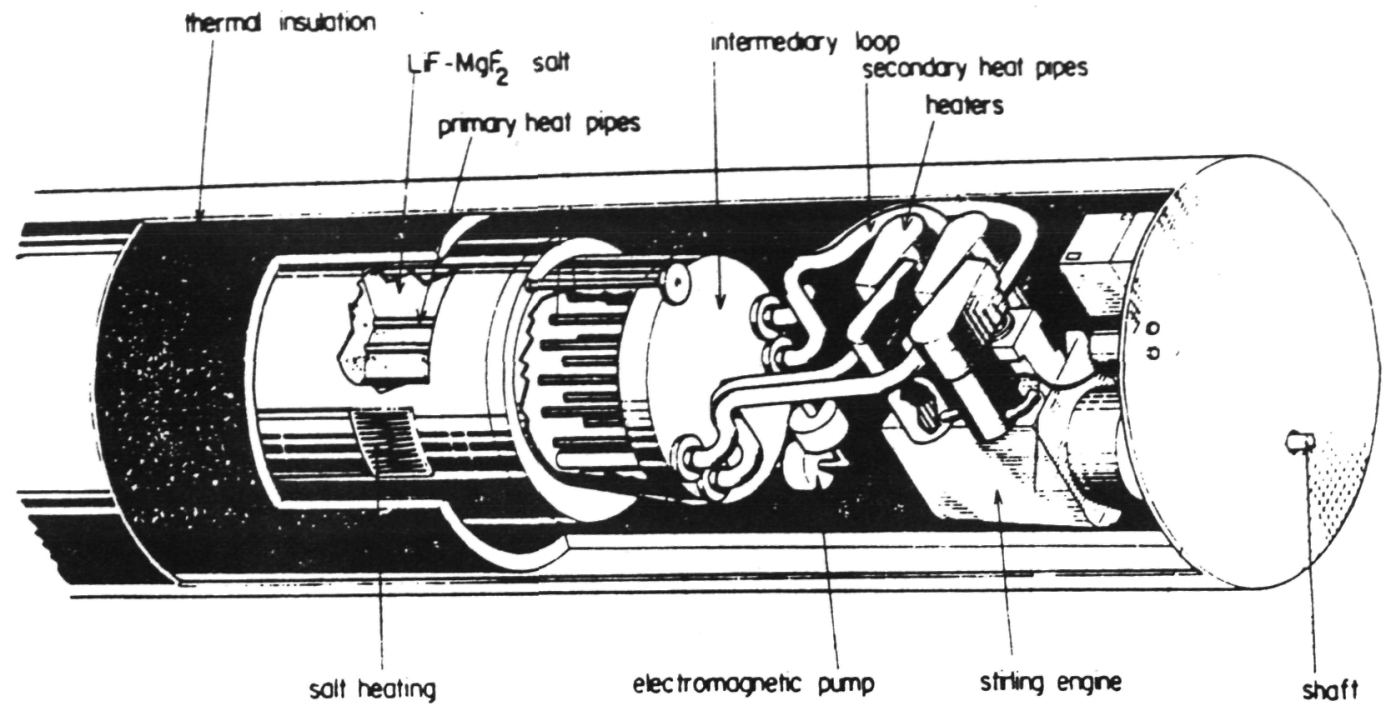

Transport of the heat from the thermal energy storage to the engine is a three step process. A large number of straight primary heat pipes transfer the heat from the solidifying salt to one end. A pumped sodium loop supplies liquid to each one of the primary heat pipes. Sodium vapor evaporates from the end of each primary heat pipe and condenses on the ends of the four secondary heat pipes which heat the four cylinders of the engine. When the sodium pump stops, the thermal connection between the thermal energy storage and the engine is soon broken. Figure 21 shows the heat exchangers for one of the four cylinders. The engine uses the block of the Renault 5 "Le Car" The piston of the gasoline engine become the cross heads of the Stirling engine. At present the engine and heat source are undergoing testing separately.

Blomass. Based Power. United Stirling has tested sawdust, straw and wood burners and wood chip gasifiers in connection with their standard engine. They found that it worked, but there was a problem of ash buildup on the heat exchangers. No application program for this engine with this fuel is known to exist at present.

Sunpower Inc., in connection with the Aid to Asia of the United States State Department and the Kumudini Welfare Trust of Bengal in Narayanganj, Bangladesh have sponsored a development program to build an air engine that could be manufactured in Bangladesh and power rice hullers with part of the rice hulls that are produced in the process. The first prototype was built at Sunpower using what was judged to be construction methods and materials that were found to be avallable in Bangladesh. Figure 22 shows a cross section of this engine. The cylinder is $30 \mathrm{~cm}$ in diameter. Tne engine is two meters long. The rice hull burner was made from a 55 gallon oil drum insulated on the inside with fire brick. A wood fire was started inside. Then the rice hulls were-blown in tangentiatly. The first prototype engine produced up to $5 \mathrm{~kW}(\mathrm{~m})$ of pawer. 
Figure 21

Heat Exchanger Module for ECA Indirectly Heated Stirling Engine

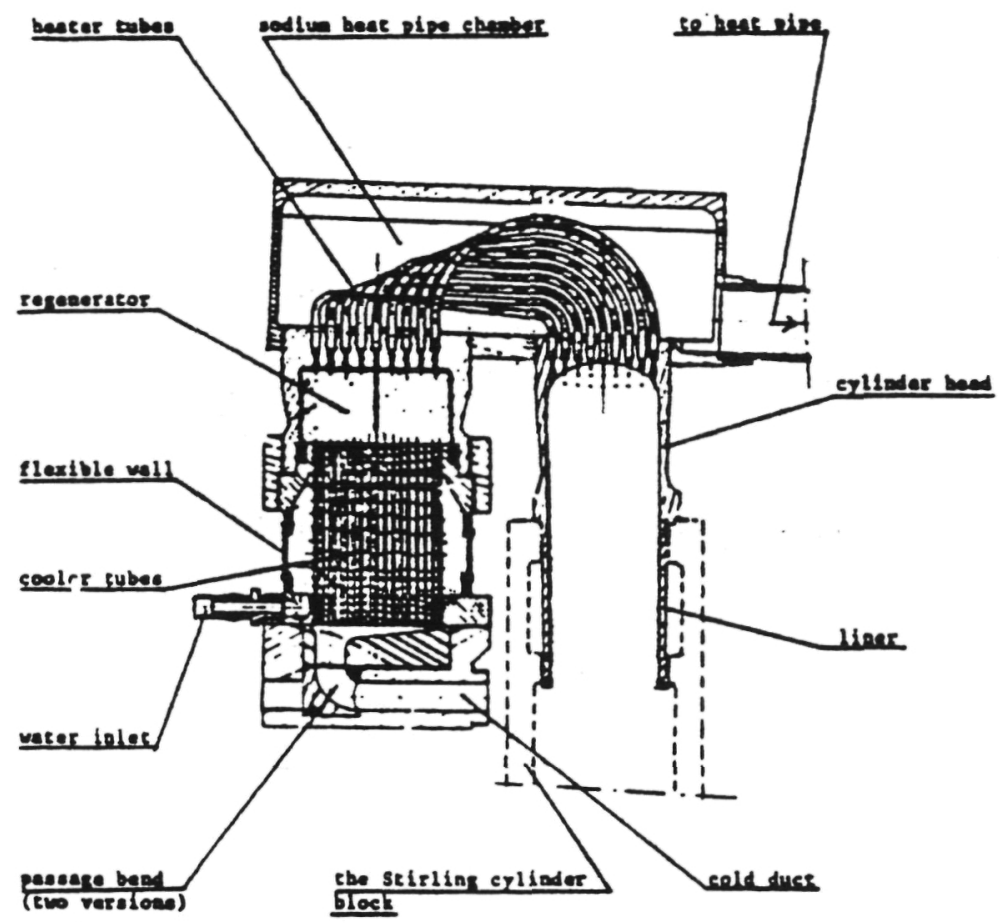

Figure 22 Cross Section of the Sunpower Rice Hull Burning Engine
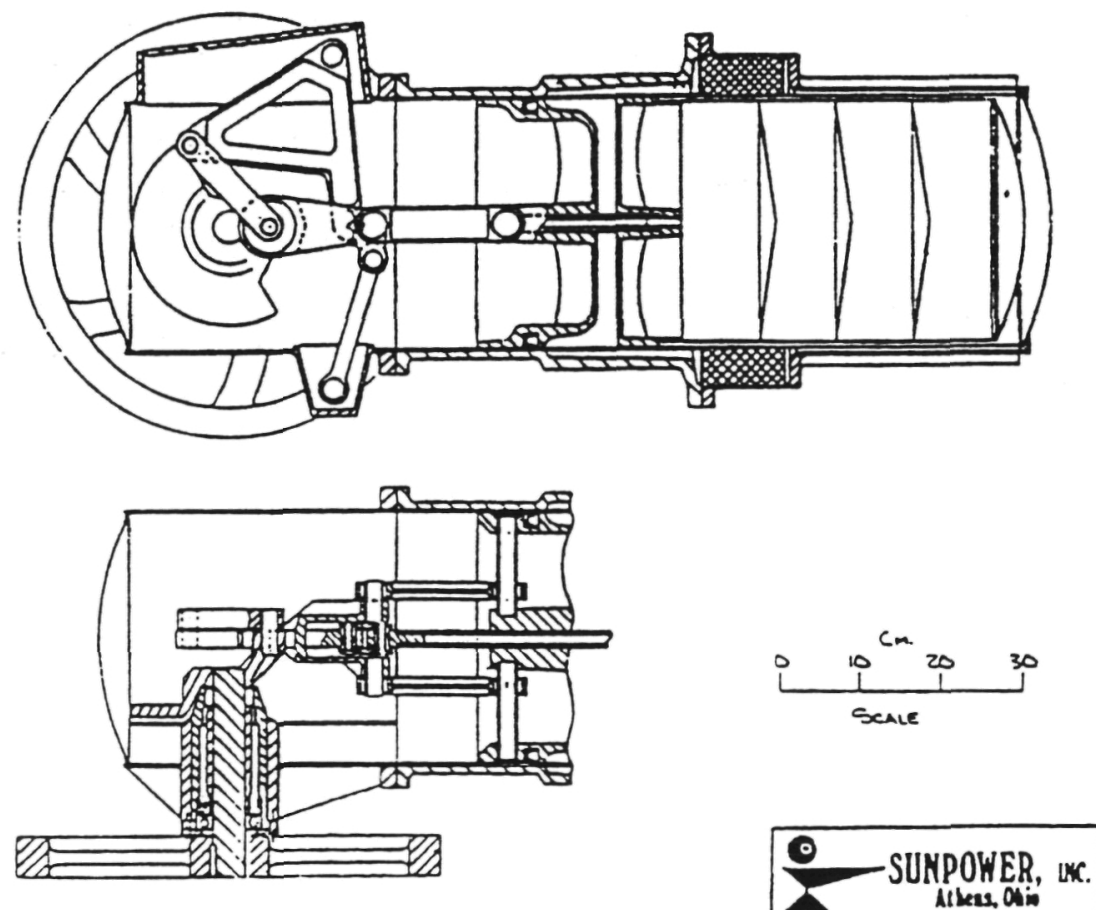
The intermediate prototype was built in Bangladesh except for the hot end. Cast iron replaced the welded steel and cast aluminum in the first prototype. No reliable measurement of power output was available, but indications are that the power of the intermediate prototype is between 1 and $2 \mathrm{~kW}(\mathrm{~m})$.

At the conclusion of the project the design of the rice husk fueled Stirling engine will be released. There will be no patents on the design in an effort to encourage the spread of this technology. In the meantime, Sunpower has built another rice hull burner that is mounted on a trailer and is available for demonstration in this country. They claim that it works better than the first one that they built. It could work as well on sawdust as on rice hulls.

A team at the University of Tokyo has been involved in an experimental program to use wood waste products to realize a local closed autonomous energy system. Specifically they are trying to build a machine that will supply heat and electric power to a greenhouse by burning locally available wood briquetts. They, have built three engines and burners. The idea is to design a machine for local use in the farm and forestry areas of Japan. To this end they are using air as a working fluid. Low cost and ease of maintenance is more important than very high efficiency. Their first engine produced $1.5 \mathrm{~kW}$ instead of their goal of $3 \mathrm{~kW}$. The efficiency was about $8 \%$. It did burn wood briquettes well enough. They are now onto their second and third design. They are looking toward reducing cost by simplified methods of manufacture.

Artificial Heart Power The original six systems studies concerning an artificial heart concluded that such a device was needed and could be built. However, only one study mentioned the Stirling engine as even a distant possibility. Currently the National Heart, Lung and Blood Institute sponsors two stirling thermal engine power sources and four battery-electric motor power sources. The electric systems have been judged more near term. However, the limited capacity of the batteries limit untethered operation to a few minutes a day with battery replacement every two years. On the other hand the stored thermal energy coupled to a Stirling engine offers 8 to 10 hours of tether-free operation after about a 1 hour charge time. One program, which started at Aerojet and is now at Nimbus, in Sacramento, CA, uses a thermocompressor to compress helium which then operates the blood pump thru a magnetic seal. The other program which started at McDonnell Douglas and is now at the University of Washington Joint Center for Graduate Study, Richland, WA, uses a freedisplacer, free-power piston, hydraulic power output engine. The blood pump is hydraulically controlled and actuated. This machine uses welded metal bellows seals that are pressure balanced. The pressure differences are taken across pistons in the hydraulic fluid. The latest engine actually built by the University of Washington group produces five watts of hydraulic power at $20 \%$ efficiency, electric heat in to hydraulic power out.

System design is similar for both heart engine contractors. Figure 23 shows'. the current system plan for installation of the JCGS system. The Nimbus system is similar. Blood is drawn from the apex of the left ventricle. It is pumped back into the descending aorta. The blood pump is outside the rib cage but inside the skin. The hydraulic actuator for the blood pump is in the space left by removing a rib. The hydraulic output engine and thermal storage is just underneath in the abdomen. 


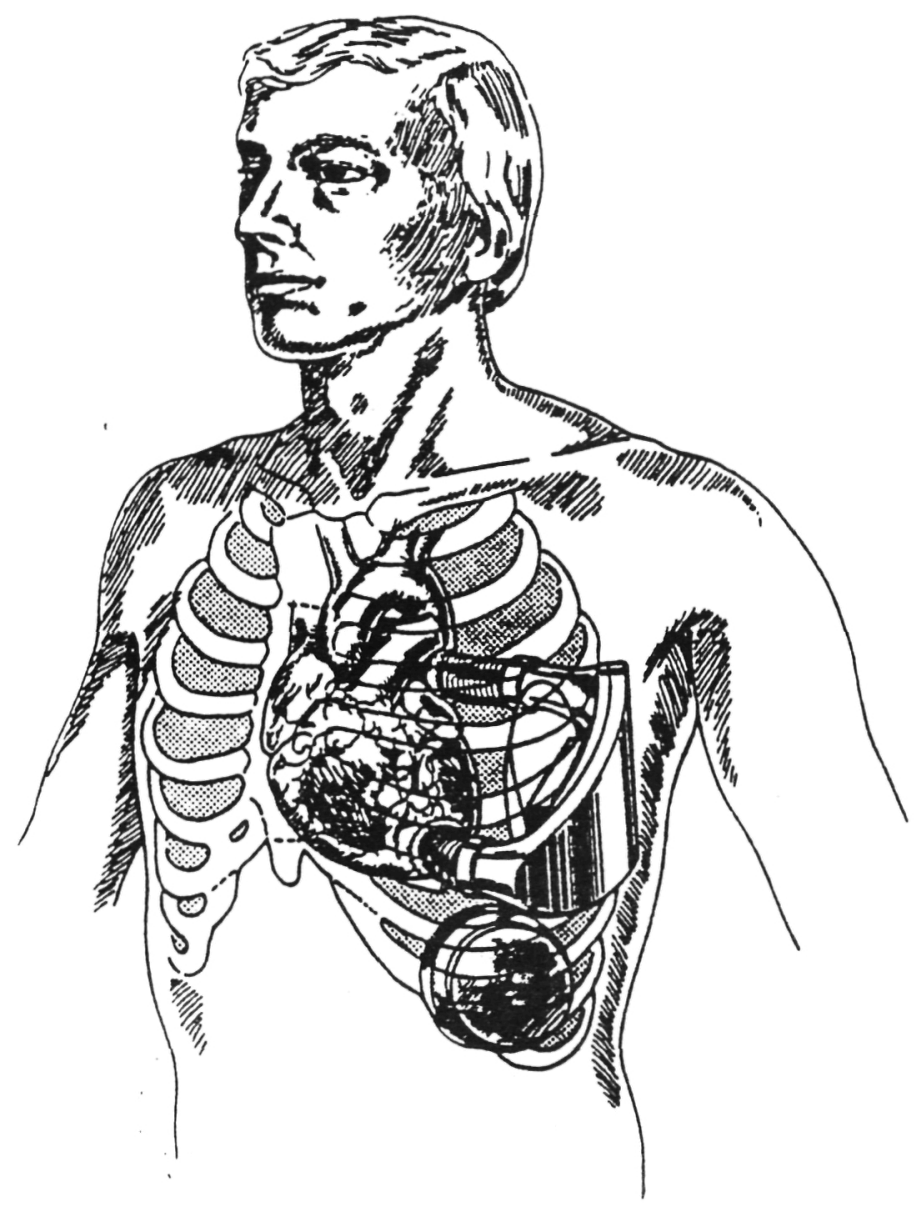

Commercial development of this machine and the competing Nimbus machine is paced by the rest of the system. The blood pump still has not been able to be used in an animal or a human for really long periods of time. The record so far is with an external pneumatic power source operating a blood pump in an animal for nine months. The record for an electrially operated blood pump in an animal is five months. The record for a Stirling engine powered blood pump in an animal is one month. An earlier model of just the engine of the artificial heart system ran over four years without stopping. Tests of later models have been conducted up to one year. At this point in the technology long term animal test are not very repeatable. The more you do the more chance that you will have a long one. Only when really long tests become the rule, not the exception, can we begin to expect a truly practical prothesis for humans. One study showed that the engine would cost $\$ 1000$ to make in lots of 10,000 per year.

\section{OTHER POSSIBLE APPLICATIONS NOT UNDER DEVELOPMENT}

Ship Power At present there are no hardware programs on Stirling engines for ships. Both Philips and United Stirling used a motor launch as a denonstration vehicle for their engine. The Japanese had an $800 \mathrm{hp.} \mathrm{ship} \mathrm{engine} \mathrm{under}$ development, which was cancelled. A number of papers have come from the Royal 
Naval Engineering College at Manadon, United Kingdom, which have suggested that diesel machines could be converted to Stirling engines and that air could be used as a convenient working fluid. The Chinese are thinking about building an engine for their river boats.

Coal Based Power There have been many studies on coal based Stirling engines but at the present time there are no active experimental projects as far as is known. In the studies that have been done it was discovered that the cost of the coal burning equipment was so much larger than the cost of the engine that coal burning technology completely dominated the cost picture. Coal based power plants have been considered for 500 to $3000 \mathrm{hp}$ stationary electric power generation, locomotive propulsion and ship propulsion.

Energy Storage Batteries and pumped hydro are the common forms of energy storage. In this paper, the combination of thermal energy storage and a Stirling engine has been mentioned for submarine power and for artificial heart power. However, no study has been made to apply the high efficiency and the compact nature of this combination to utility peak shaving or to wind power energy storage. Some solar energy receivers do incorporate thermal energy storage.

\section{INFORMATION SOURCES}

I would like to thank all the centers of Stirling machine development mentioned in this paper for their generous contribution of information and visuals that made possible this paper. Their willingness to release the very latest information and to review the draft of this manuscript is very much appreciated. However, there was not time for a final review. Martini Engineering takes full responsibility for the contents. We apologize for any errors or omissions in the text.

Conventional references have not been given in this paper. Instead suggestions are made to the reader how he may learn more about Stirling engines, keep up to date in this field, and contact the stirling engine developers as needed.

There is one standard text on cryogenic refrigeration. A large portion of this text is devoted to machines based upon the Stirling cycle and related cycles. The text is:

G. Walker, "Cryocoolers" (2 volumes) Plenum Press (1983)

There are two standard texts that explain all that is going on and has gone on in Stirling engines. Each author interjects his own opinions into the text, which is valuable as well. The texts are:

G. Walker, "Stirling Engines", Clarendon Press, Oxford (1980)

G.T.Reader and C. Hooper, "Stirling Engines", E. \& F. N. Spon (1983)

To learn more specifically how to compute the performance of a stirling engine two more books are recommended:

I. Urieli and D. M. Berchiowitz, "Stirling Cycle Engine Analysis", Adam Hilger Ltd., Bristol (1984) 
W. R. Martini, "Stirling Engine Design Manual, Second Edition" DOE/NASA/3194-1 or Martini Engineering (1983)

In addition, three other books that are full of ideas and information are recommended:

C. West, "Liquid Piston Stirling Engines" Van Nostrand Reinhold Co. (1983)

I. Kolin, "Isothermal Stirling Cycle Engine", Sveucilisna naklada Liber, Zagreb, Yugoslavia (1983)

G. Walker and J. R. Senft "Free Piston Stirling Engines" in publication. (1984)

A very good way to keep up to date in the field of Stirling engines is to subscribe to the Stirling Engine Newsletter. This has been published quarterly by Martini Engineering since 1978. A cumulative index to this publication is planned for the nuar future.

Two directories have been published for the stirling engine industry. The 1984 edition is almost published. This gives the names and addresses and current program for all the active workers in the stirling engine field and what their present program is.

An Index to the Stirling Engine literature is published which lists all the technical literature in the world relative to stirling engines. Martini Engineering maintains a file containing copies of most of this literature and will send out copies on request. Also all of the books recommended above are available from Martini Engineering as a service to the Stirling engine community. Finally, video tapes about stirling engines and model engines and kits for somewhat larger engines are also available. 
TECHNICAL REPORT STANDARD TITLE PAGE

\begin{tabular}{|c|c|c|}
\hline 1. Report No. 85-70 & 2. Government Accession No. & 3. Recipient's Catalog No. \\
\hline \multirow{2}{*}{\multicolumn{2}{|c|}{$\begin{array}{l}\text { 4. Title and Subtifle } \\
\text { Stirling Engine Alternatives for the } \\
\text { Terrestrial Solar Application }\end{array}$}} & $\begin{array}{l}\text { 5. Report Date } \\
\text { October } 1985\end{array}$ \\
\hline & & 6. Performing Organization Code \\
\hline \multicolumn{2}{|l|}{$\begin{array}{l}\text { 7. Author }(s) \\
\text { J. Stearns }\end{array}$} & 8. Performing Organization Report No. \\
\hline \multirow{3}{*}{\multicolumn{2}{|c|}{$\begin{array}{l}\text { 9. Performing Orgonization Name and Address } \\
\text { JET PROPULSION LABORATORY } \\
\text { California Institute of Technology } \\
4800 \text { Oak Grove Drive } \\
\text { Pasadena, California } 91109\end{array}$}} & 10. Work Unit No. \\
\hline & & $\begin{array}{c}11 . \text { Controct or Gront No. } \\
\text { NAS7-918 }\end{array}$ \\
\hline & & 13. Type of Report and Period Covered \\
\hline \multirow{2}{*}{\multicolumn{2}{|c|}{$\begin{array}{l}\text { 12. Sponsoring Agency Nome and Address } \\
\text { NATIONAL AERONAUTICS AND SPACE ADMINISTRATION } \\
\text { Washington, D.C. } 20546\end{array}$}} & JPL Publication \\
\hline & & 14. Sponsoring Agency Code \\
\hline
\end{tabular}

15. Supplementary Notes Sponsored by the U.S. Department of Energy through Interagency Agreement DE-AM04-80AL13137 with NASA; also identified as DOE/JPL-1060-91 and as JPL Project No. 5105-162 (RTOP or Customer Code 776-81-62).

16. Abstract

The first phase of the present study of Stirling engine alternatives for solar thermal-electric generation has been completed. Development risk levels are considered to be high for all engines evaluated. Free-piston type and Ringbom-type Stirling engine-alternators are not yet developed for the 25-to-50-kW electrical power range, although smaller machines have demonstrated the inherent robustness of the machines. Kinematic-type Stirling engines are presently achieving a 3500-hr lifetime or longer on critical components, and lifetime must still be further extended for the solar application. Operational and technical characteristics of all types of Stirling engines have been reviewed with engine developers. Technical work of merit in progress in each engine development organization should be recognized and supported in an appropriate manner.

\begin{tabular}{|l|l|l|l|l|}
\hline 17. Key Worcs (Selected by Author(s)) & \multicolumn{3}{l|}{ 18. Distribution Statement } \\
$\begin{array}{c}\text { Systems Analysis } \\
\text { Power Sources }\end{array}$ & \multicolumn{3}{|c|}{ Unclassified-Unlimited } \\
\hline $\begin{array}{l}\text { 19. Security Closif. (of this report) } \\
\text { Unclassified }\end{array}$ & $\begin{array}{r}\text { 20. Security Clossif. (of this poge) } \\
\text { Unclassified }\end{array}$ & $\begin{array}{c}\text { 21. No. of Poges } \\
\text { 22. Price }\end{array}$ \\
\hline
\end{tabular}

